\title{
22. MID-CRETACEOUS PLANKTONIC FORAMINIFERAL BIOSTRATIGRAPHY OFF CENTRAL MOROCCO, DEEP SEA DRILLING PROJECT LEG 79, SITES 545 AND 5471
}

\author{
R. Mark Leckie, Department of Geological Sciences, University of Colorado ${ }^{2}$
}

\begin{abstract}
Sites 545 and 547 collectively penetrated $629 \mathrm{~m}$ of mid-Cretaceous strata (upper Aptian to upper Cenomanian) off central Morocco during Leg 79 of the Deep Sea Drilling Project. Site 545, at the base of the steep Mazagan Escarpment, records a virtually complete succession of hemipelagic sediments of early late Aptian to middle Cenomanian age. Minor faunal recycling occurred throughout much of the upper Aptian to middle Albian part of the sequence (Cores 55 through 41), reflecting bottom currents along the Mazagan Escarpment. This may be related to the strong upwelling régime and high surface water productivity over Site 545 during the latest Aptian through middle Albian. The upwelling system ceased rather abruptly in this area in late middle Albian time. Recycling of older strata by bottom currents also ceased in the late middle Albian and resulted in a slower average accumulation rate in the upper Albian to middle Cenomanian section of Site 545 (Cores 40 through 28 ). However, intervals of pebbly claystone conglomerates in Cores 40 and 34 record sporadic instability in the slope adjacent to Site 545 . Site 547 , located only about $15 \mathrm{~km}$ seaward, is situated in a small sub-basin adjacent to the basement block drilled by Site 544. It contains an expanded upper Albian to upper Cenomanian sequence as a result of the numerous conglomeratic intervals throughout much of the section. In contrast to Site 545, the conglomerates were not derived from older strata cropping out on the Mazagan Escarpment; rather, they originated penecontemporaneously from a local unstable slope.

A detailed biostratigraphic framework based on planktonic foraminifers is established for the mid-Cretaceous sections of Sites 545 and 547 and a new composite zonal scheme is proposed for the early late Aptian through early late Cenomanian interval. Fifty-five species are recognized and illustrated.
\end{abstract}

\section{INTRODUCTION}

DSDP Sites 545 and 547 recovered a virtually complete succession of strata of early late Aptian to early late Cenomanian age off central Morocco during Leg 79 of the Deep Sea Drilling Project (Figs 1-4). Planktonic foraminifers are abundant, diverse, and generally well preserved throughout the section, permitting a detailed biostratigraphic framework to be established.

The mid-Cretaceous section is predominantly composed of nannofossil claystones with subordinate pebbly claystone intervals, particularly common in the Site 547 sequence (Figs. 5, 6). Redeposition is a characteristic feature of the continental margin off central Morocco from Early Jurassic through Late Tertiary times. Although Site 547 contains abundant conglomeratic intervals, faunal reworking is not an obvious problem. However, at Site 545, at the base of the Mazagan Escarpment, extended ranges of several late Aptian planktonic foraminiferal taxa suggest that faunal mixing is common in the upper Aptian through middle Albian part of the sequence and may be associated with upwelling-related bottom currents.

\section{Site 545}

The mid-Cretaceous section of Site 545 is $278.7 \mathrm{~m}$ thick and ranges in age from early late Aptian (Globigerinelloides ferreolensis Zone) to middle Cenomanian

\footnotetext{
${ }^{1}$ Hinz, K., Winterer, E. L., et al., Init. Repts. DSDP, 79: Washington (U.S. Govt. Printing Office).

2 Present address: Department of Geology and Geography, University of Massachusetts, Amherst, MA 01003
}

(Rotalipora reicheli Zone). The lower $113 \mathrm{~m}$ (Cores 45 through 56) is dominated by greenish gray nannofossil claystone with subordinate clayey nannofossil chalks. A pervasive fabric of microfaulting and microfolding characterizes this part of the section. A fault mélange zone occurs in the lowermost part of Core 55 and upper part of Core 56. The upper $166 \mathrm{~m}$ (Cores 28 through 44 ) is composed of grayish green and grayish olive green nannofossil-bearing clay/claystone and clayey nannofossil chalks. Two intervals of intraclastic clayey conglomerates and pebbly or cobbly mudstones occur in Cores 34 and 40 . The only representation of the widespread midCretaceous black shale facies occurs in two thin, finely laminated, olive black claystone intervals in Sections 545-42-1, 2 and 545-43-7. The hemipelagic sediments accumulated at an average rate of $20 \mathrm{~m} / \mathrm{m}$.y. for the upper Aptian to middle Albian part of the sequence (Cores 41 through 56) and at an average rate of $11 \mathrm{~m} / \mathrm{m}$.y. for the upper Albian to middle Cenomanian (Cores 28 through 40).

The mid-Cretaceous is unconformably bounded by lower Miocene radiolarian-bearing nannofossil chalk above and by Upper Jurassic shallow-water dolomitized limestone below (see site chapter, this volume).

\section{Site 547}

The mid-Cretaceous section of Site 547 (Holes 547A and 547B) is 350.4 meters thick and ranges in age from late middle Albian (Ticinella praeticinensis Zone) to early late Cenomanian (Rotalipora cushmani Zone). The dominant lithology is dark greenish gray, grayish olive green, and grayish green nannofossil-bearing claystone with subordinate amounts of pebbly-cobbly claystone and mud- 


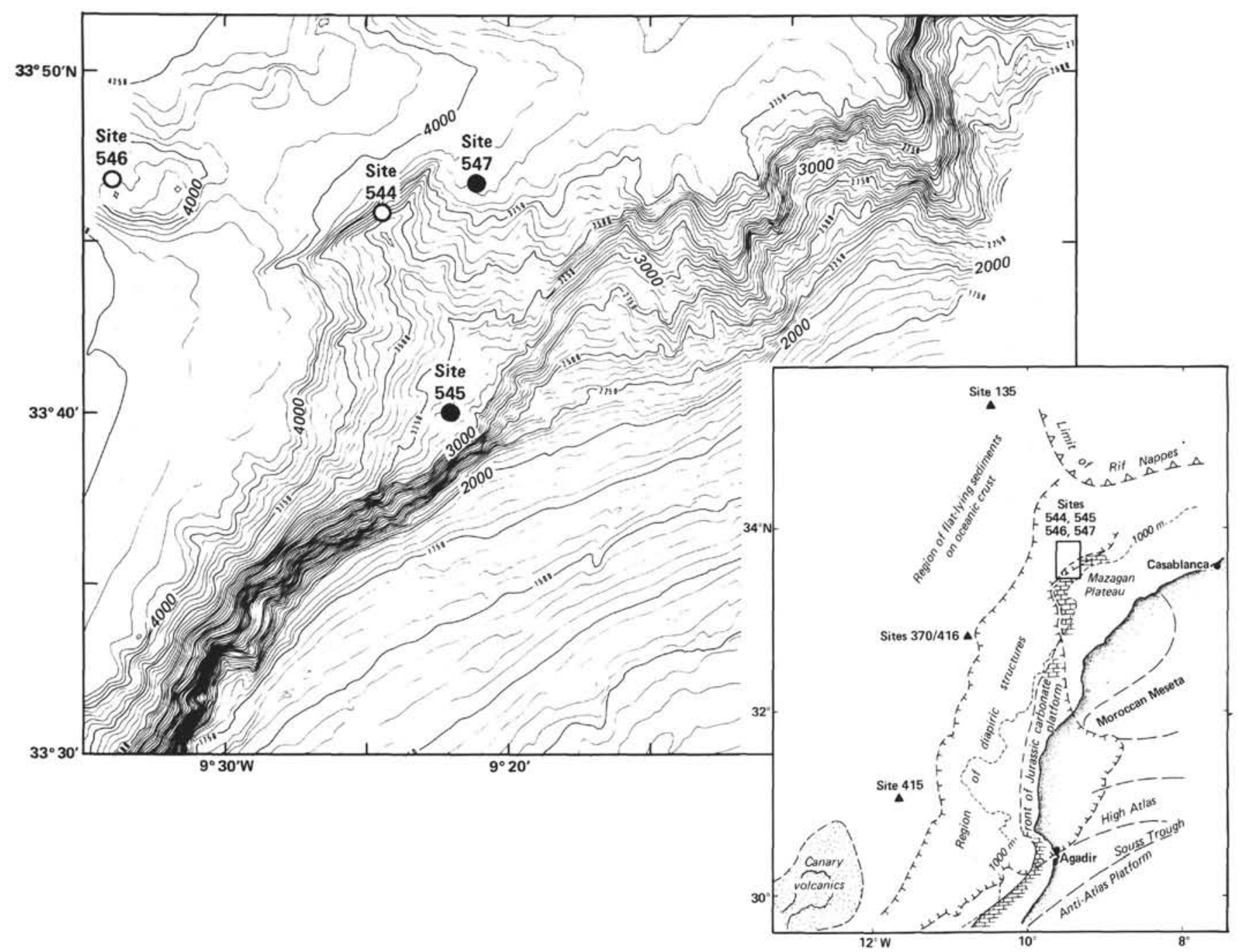

Figure 1. Map showing the regional setting of the Mazagan Plateau and location of sites drilled during Leg 79.

stone. The Site 547 conglomeratic intervals are considerably more frequent and thicker than those of Site 545 and may explain the higher sediment accumulation rates at Site 547; these averaged greater than $30 \mathrm{~m} / \mathrm{m}$.y.

This sequence is unconformably bounded by Campanian clayey nannofossil and foraminiferal-nannofossil chalks above, and by a very thin Neocomian section which caps an earliest Cretaceous to Jurassic carbonate section below.

\section{TECTONIC SETTING AND FAUNAL RECYCLING}

Site 545 was drilled at the foot of the steep Mazagan Escarpment in a water depth of $3150 \mathrm{~m}$ (Figs. 2, 3). In the Late Jurassic, Site 545 was situated in the shallowwater environment of a carbonate platform, but during the latest Jurassic and Early Cretaceous carbonate accumulation could not keep pace with subsidence. Differential subsidence along listric normal faults resulted in the formation of the Mazagan Escarpment at the seaward edge of the broad Mazagan Plateau. By mid-Cretaceous time, Site 545 had probably attained middle to upper bathyal depths at the base of the steepening escarpment.
Extended ranges of several late Aptian planktonic foraminiferal species suggest that continuous recycling of penecontemporaneous and older faunas occurred throughout the upper Aptian to middle Albian interval (Cores 41 through 55). These taxa include Globigerinelloides blowi s.l., G. aptiense, G. algerianus, and Hedbergella aff. sigali. Regardless of this faunal mixing, a normal foraminiferal succession occurs throughout the section. The redeposited sediment and fauna probably originated from the Mazagan Escarpment. The lack of conglomerate beds suggests that bottom current scour may be responsible for the faunal mixing, although slumping of semilithified sediments also occurred. Bottom current erosion and entrainment of sediment is reflected in the higher accumulation rates in the upper Aptian to middle Albian part of the sequence compared with the overlying upper Albian to middle Cenomanian strata.

A minor erosional unconformity represented by pebbly claystone conglomerates is present in the lower part of Core 545-40, probably within the late Albian Biticinella breggiensis Zone. Core 40 contains numerous conglomerates throughout and, near the top, a thin pebble bed in 545-40-1, 8-10 cm, contains a mixed late Albian 


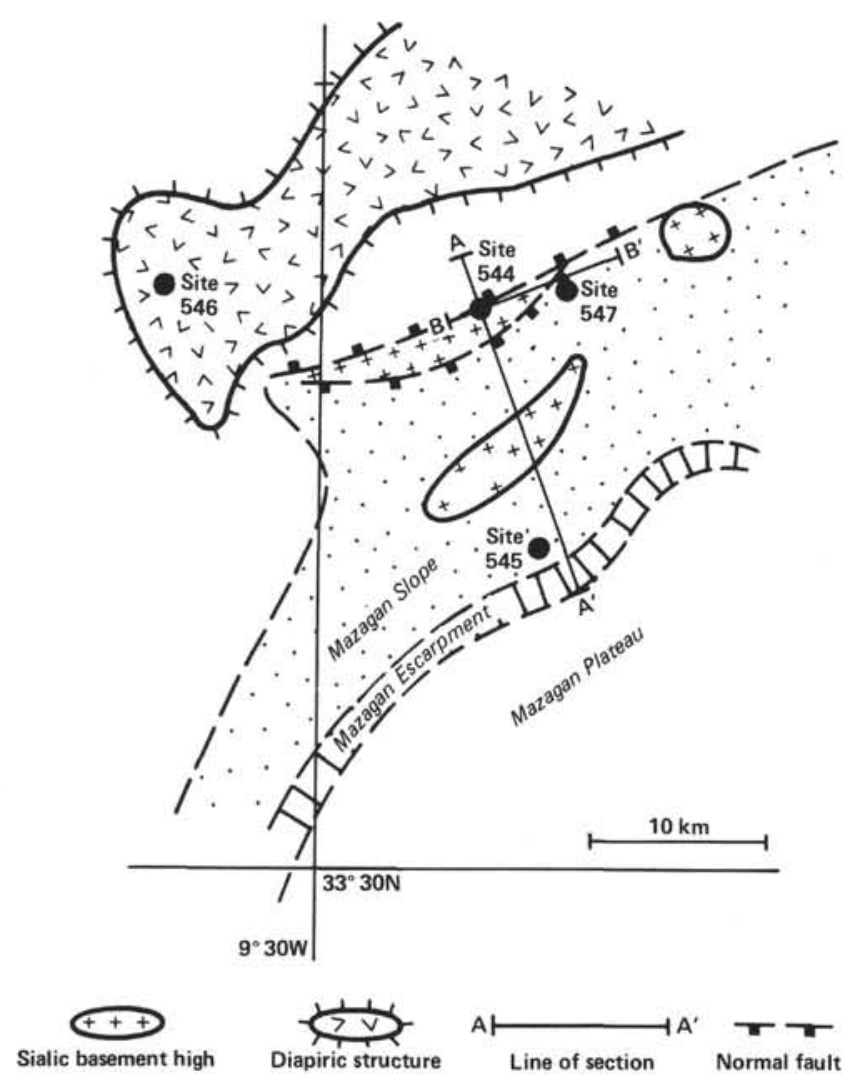

Figure 2. Mazagan Escarpment area, showing sites drilled during Leg 79 , location of lines of cross sections, and major geologic features.

and latest Albian fauna (B. breggiensis and Planomalina praebuxtorfi-buxtorfi zones). This is overlain by a normal succession of the $B$. breggiensis Zone, the $P$. praebuxtorfi Subzone and the Rotalipora appenninica Subzone (Table 1, later). It appears that the pebble bed at the top of Section 545-40-1 represents a period of erosion in the latest Albian (P. praebuxtorfi-buxtorfi Zone) during which a slump block containing a normal succession of late Albian zones slid onto the site. The slumped block contains the portion of the sequence that had been eroded from the site earlier, resulting in a virtually complete upper Albian section.

Another conglomeratic interval in Core 545-34 (lower Cenomanian) contains clasts of upper Aptian strata as evidenced by planktonic foraminifers (Table 1, later). The clasts probably originated from the Mazagan Escarpment.

Site 547 is situated in a small sub-basin on the flank of a structural basement high (Figs. 2, 4). It was drilled in a water depth of $3940 \mathrm{~m}$. During Early Jurassic rifting, Site 547 subsided rapidly and nodular limestones were deposited in a basinal environment. These were followed by deposition of sandy breccias and finally, during the Late Jurassic, by deposition of pelagic carbonates on a progressively deepening platform slope (Steiger and Jansa, this volume). This area continued to subside during the Early Cretaceous and by the mid-Cretaceous had probably reached middle bathyal depths.

In contrast to Site 545, the mid-Cretaceous section at Site 547 (middle Albian to upper Cenomanian) contains frequent and thicker conglomeratic intervals. However, planktonic foraminiferal evidence suggests that most of the redeposition is penecontemporaneous, and foraminiferal ranges do not extend upward beyond their expected extinction datums as they do in the upper Aptian to middle Albian section of Site 545. The lack of recycled older faunas suggests that the conglomerate beds were not derived from the Mazagan Escarpment some $15-20 \mathrm{~km}$ away, but were derived locally.

\section{UPWELLING OFF THE MAZAGAN PLATEAU}

There is strong evidence from Site 545 of significant upwelling and associated fertile surface waters off central Morocco during latest Aptian through middle Albian time. This is primarily indicated by the accumulation of siliceous skeletons (radiolarians and sponge spicules) and their presence as the dominant biotic elements from the upper part of Core 50 through the lower part of Core 41 (Fig. 7). Because the oceans are undersaturated with respect to silica, preservation of siliceous skeletons is enhanced in the sedimentary record during periods of

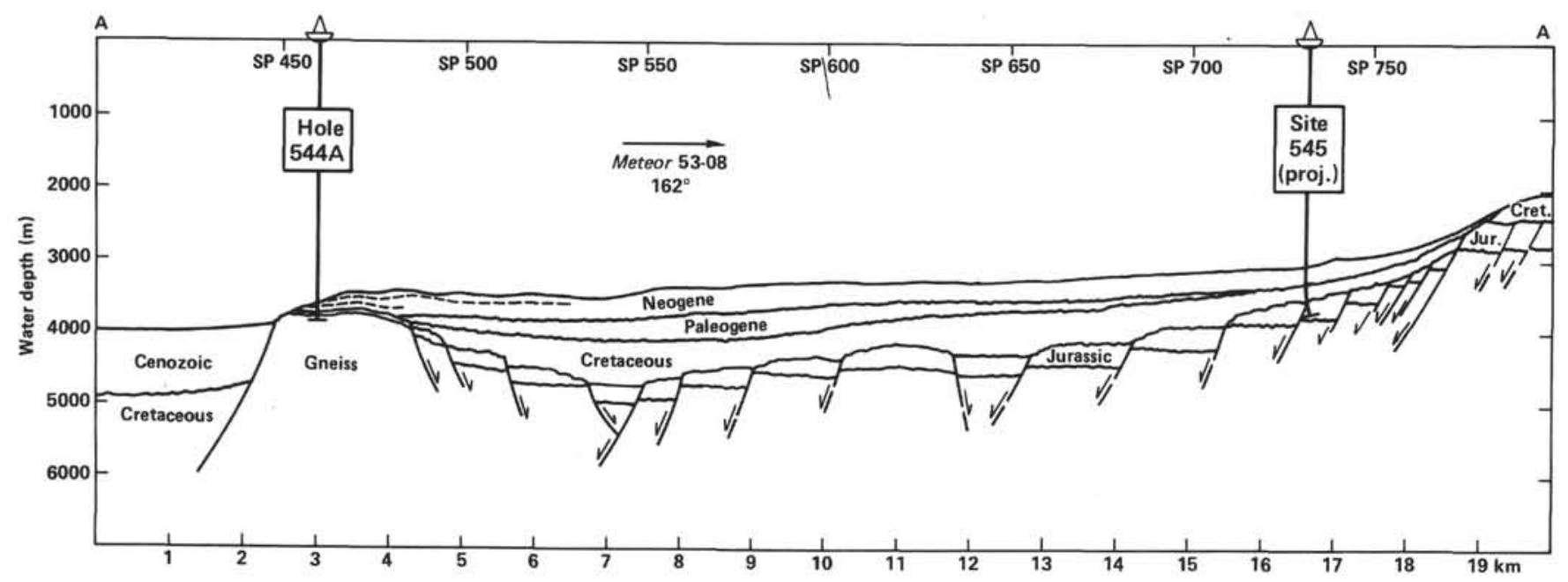

Figure 3. Geologic cross section along Meteor seismic profile 53-08, through Sites 544 and 545 (projected into line). 


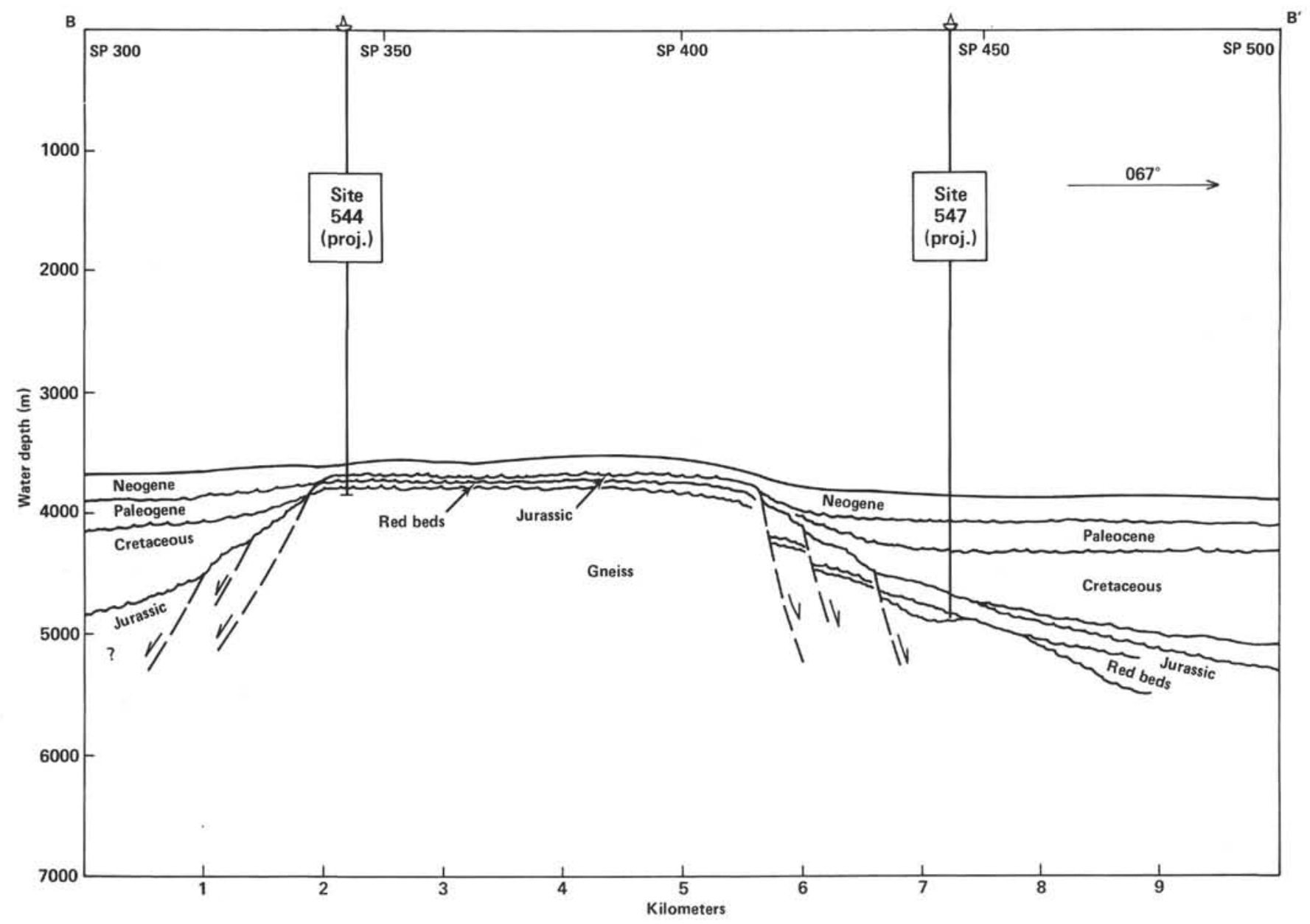

Figure 4. Geologic cross section along Meteor seismic profile 53-10, through Sites 544 and 547 (projected into line).

greater surface water productivity and net accumulation of silica at the seafloor. Therefore, the preservation of significant amounts of siliceous skeletons in the ancient record is indicative of upwelling of nutrient-rich deep water and high biologic productivity (see discussions by Berger, 1970; Diester-Haass, 1978). Other evidence supporting upwelling is the sharp increase in benthic foraminifers relative to planktonic forms, the drop in planktonic foraminiferal diversity, and the increase in fish debris (Fig. 7). The upwelling probably occurred over the outer Mazagan Plateau and upper Mazagan Escarpment, adjacent to Site 545 .

Development of this upwelling system over Site 545 shows the first minor pulses of radiolarians in Cores 55, 54 , and 53 with a greater pulse through Cores 52 and 51 . Then beginning in the upper part of Core 50, both radiolarians and sponge spicules significantly increase. From there, the proportion of radiolarians to planktonic foraminifers and spicules to benthic foraminifers steadily increases as these siliceous components dominate the assemblages in the $>63 \mu \mathrm{m}$ fraction through the lower part of Core 41. The abundances of radiolarians and sponge spicules drop off sharply in Section 545-41-3 and are virtually absent above the minor erosional hiatus in the lowermost part of Core 40 .
Foraminiferal assemblages were notably affected by the upwelling regime. Foraminifers in general have their lowest proportion, relative to other biota, in the $>63 \mu \mathrm{m}$ fraction for the interval from Core 47 through the lower part of Core 41 . The planktonic to benthic ratio steadily decreases from Cores 55 through 48 . Then in Core 47 there is a sharp drop in the proportion of planktonics to benthics (Fig. 7; compare with data from Site 547, Fig. 8). In fertile regions along the present Northwest African margin, Diester-Haass (1978) also noted that benthic foraminifers showed a greater increase in abundance relative to planktonic forms. In the mid-Cretaceous at Site 545 , several environmental factors may contribute to this trend. One such factor may be dissolution of planktonic foraminifers, either as they fell through the water column or reacted with interstitial waters in the bottom sediments. It has been shown that the present-day calcite compensation depth (CCD) commonly rises under regions where fertility is greater (Berger, 1970; DiesterHaass, 1978); however, benthic foraminiferal assemblages clearly indicate that Site 545 was well above the lysocline in the mid-Cretaceous. Selective dissolution of planktonic taxa may be partially responsible for the drop in simple diversity (Fig. 7) and/or the exclusion of such planktonic species as Ticinella roberti s.l., T. primula, 
Lat. $33^{\circ} 90.86^{\prime} \mathrm{N}$, Long, $9^{\circ} 21.88^{\prime} \mathrm{W}$; Depth $3150 \mathrm{~m}$

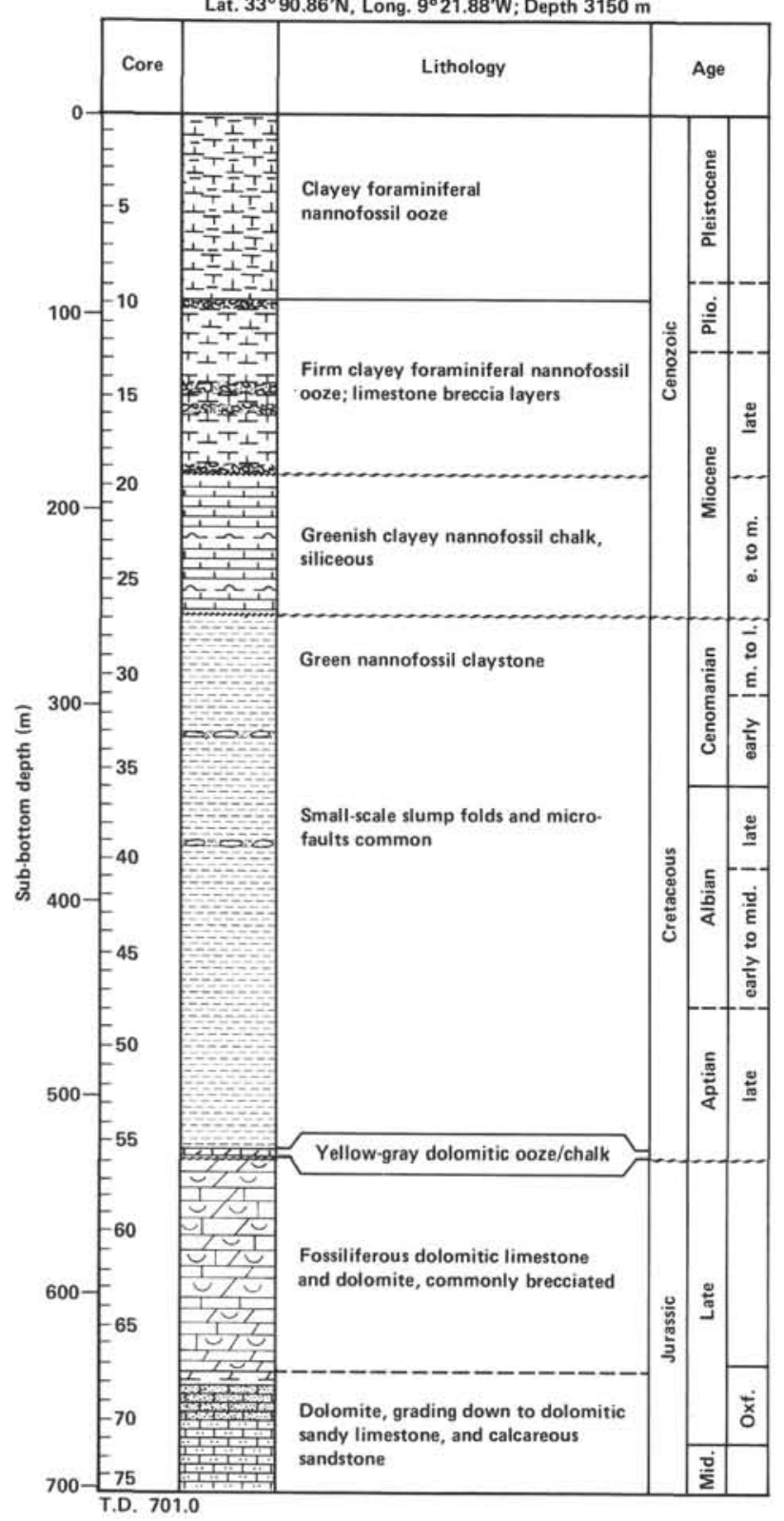

Figure 5. Lithologic column drilled at Site 545.

and $T$. praeticinensis (especially in Cores 43 through 41 ), although it is difficult to imagine that such apparently robust taxa were more susceptible to dissolution than Hedbergella delrioensis.

The decrease in diversity and exclusion of specialized planktonic taxa may also result from upwelled cool, nutrient-rich bottom water. Butt (1982) proposed that the production of cherts and phosphates, and the interbedded deposits containing assemblages of radiolarians and nonkeeled planktonic foraminifers during the early Turonian of Morocco signalled the occurrence of major coastal upwelling of cold water masses (Antarctic Current). Butt interpreted the low-diversity, high-density hedbergellid fauna as representing a cool-water assemblage. However, this interpretation for the early Turonian must be considered in light of the dearth of keeled plankton-

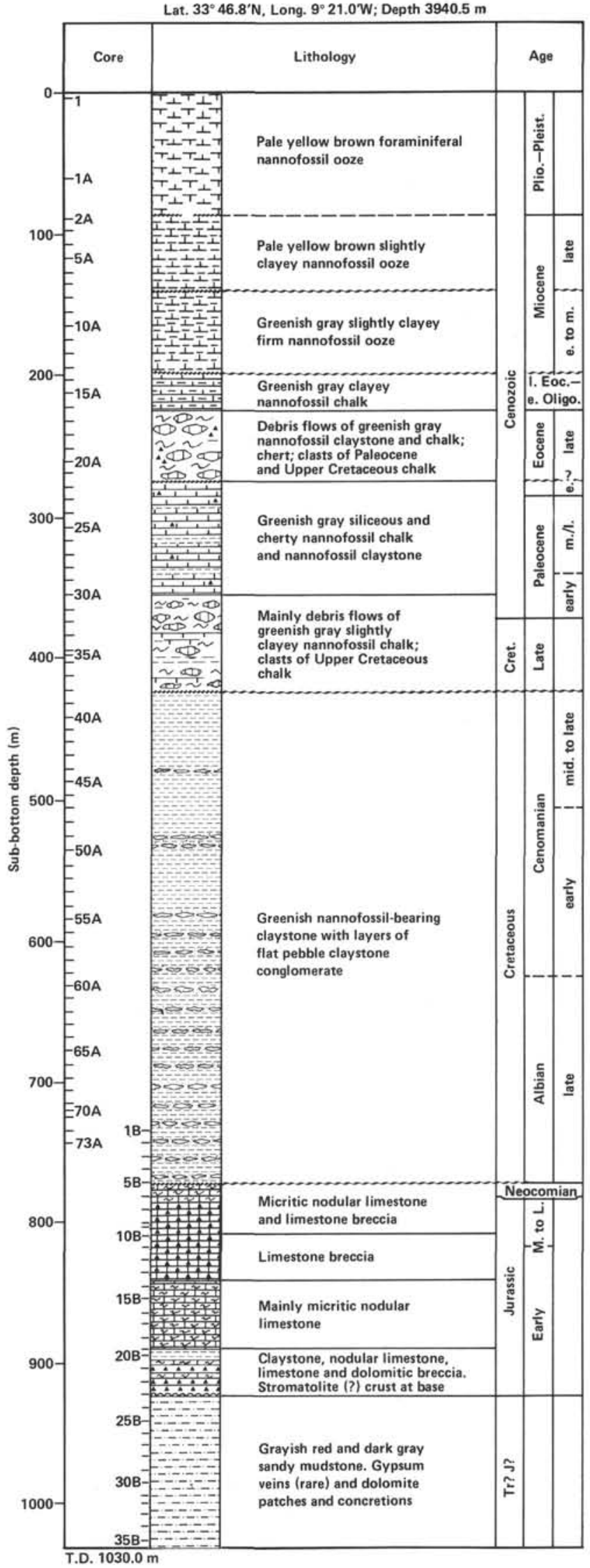

Figure 6. Lithologic column drilled at Site 547. 


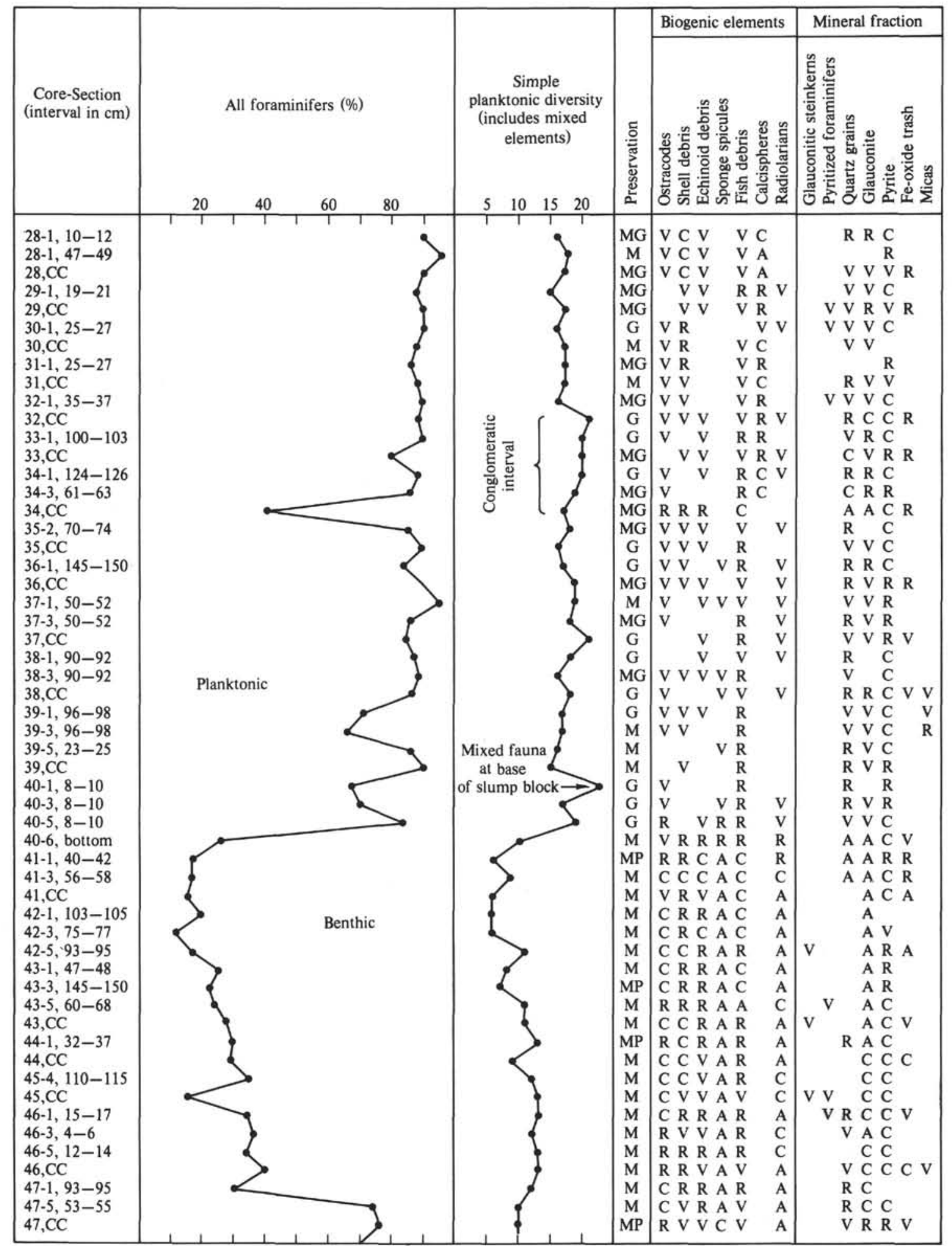

Figure 7. Distribution and character of selected biogenic and lithologic components at Site 545. Relative abundance of planktonic and benthic foraminifers based on counts of 300 specimens from the $>63 \mu \mathrm{m}$ fraction. Simple planktonic diversity includes mixed elements. Foraminiferal preservation: $\mathbf{G}=$ good, $\mathbf{M G}=$ moderately good, $\mathbf{M}=$ moderate, $\mathrm{MP}=$ moderately poor, $\mathbf{P}=$ poor. Relative abundances of other biogenic and mineral components based on proportion relative to foraminifers $(\mathrm{P}+\mathrm{B}): 25 \%=$ abundant, $5-25 \%=$ common, $1-5 \%=$ rare, $1 \%$ very rare. 


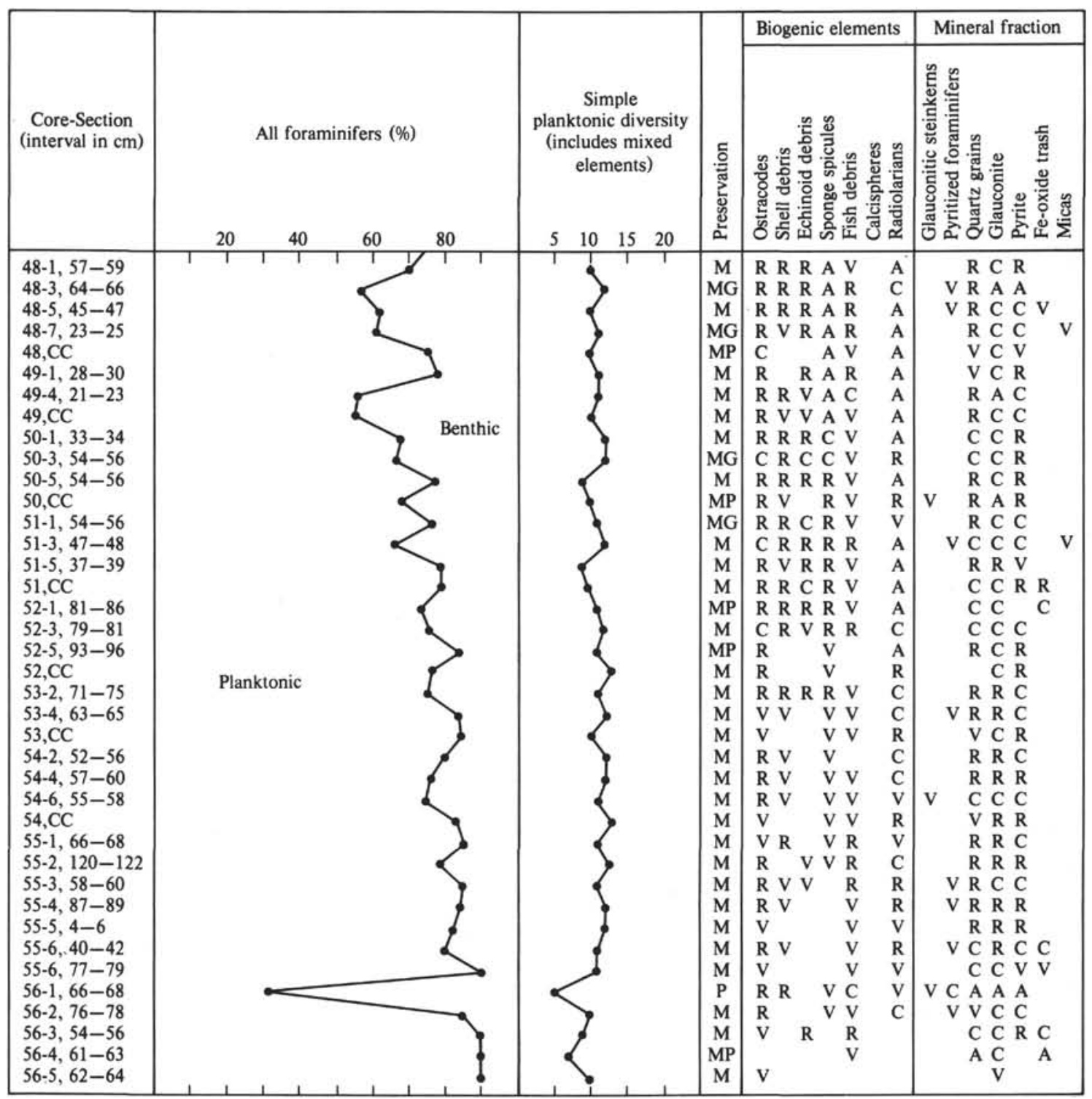

Figure 7. (Continued).

ics at this time after the disappearance of the late Cenomanian keeled assemblages of Rotalipora and Praeglobotruncana, ("zone à grandes globigérines"; Van Hinte, 1976) and the radiation of the marginotruncanids during the middle and late Turonian (see Robaszynski and Caron, 1979). The middle Albian records a similar period of low-diversity faunas composed of simpler forms which preceded a radiation of specialized, morphologically advanced taxa in the late Albian. The suggestion of cool bottom waters bears importantly on the paleoceanography of the Atlantic Ocean, especially its thermal gradient and the potential source of such cold bottom waters.

The Aptian-Albian and Cenomanian-Turonian Oceanic Anoxic Events (OAE) of Arthur and Schlanger (1979) corresponded to times of rising sea levels (Fig. 9). These were also times of upwelling along the Northwest African continental margin and of low-diversity (oligotaxic) planktonic foraminiferal assemblages dominated by sim- ple morphologic forms. Wonders (1980) noted the correspondence between OAE's and the evolution and faunal turnovers of Tethyan planktonic foraminifers. He proposed two models to explain how the ecologic niche of the deep-dwelling, specialized planktonic foraminifers may disappear: either by absence of the thermocline whereby vertical mixing of the surface waters expands to much greater depths, or anoxic conditions in the deeper waters.

An intensified oxygen minimum zone off central Morocco during the latest Aptian and early Albian is probably responsible for the loss of Planomalina cheniourensis, the earliest keeled planktonic foraminifer, and a simultaneous disappearance of several other planktonic taxa favoring the simpler morphologic forms. The vertical expansion of the oxygen minimum zone peaked during the middle Albian (Cores 545-43 to 545-41), when all species of Ticinella disappeared from the planktonic foraminiferal populations and oxygen-poor water im- 


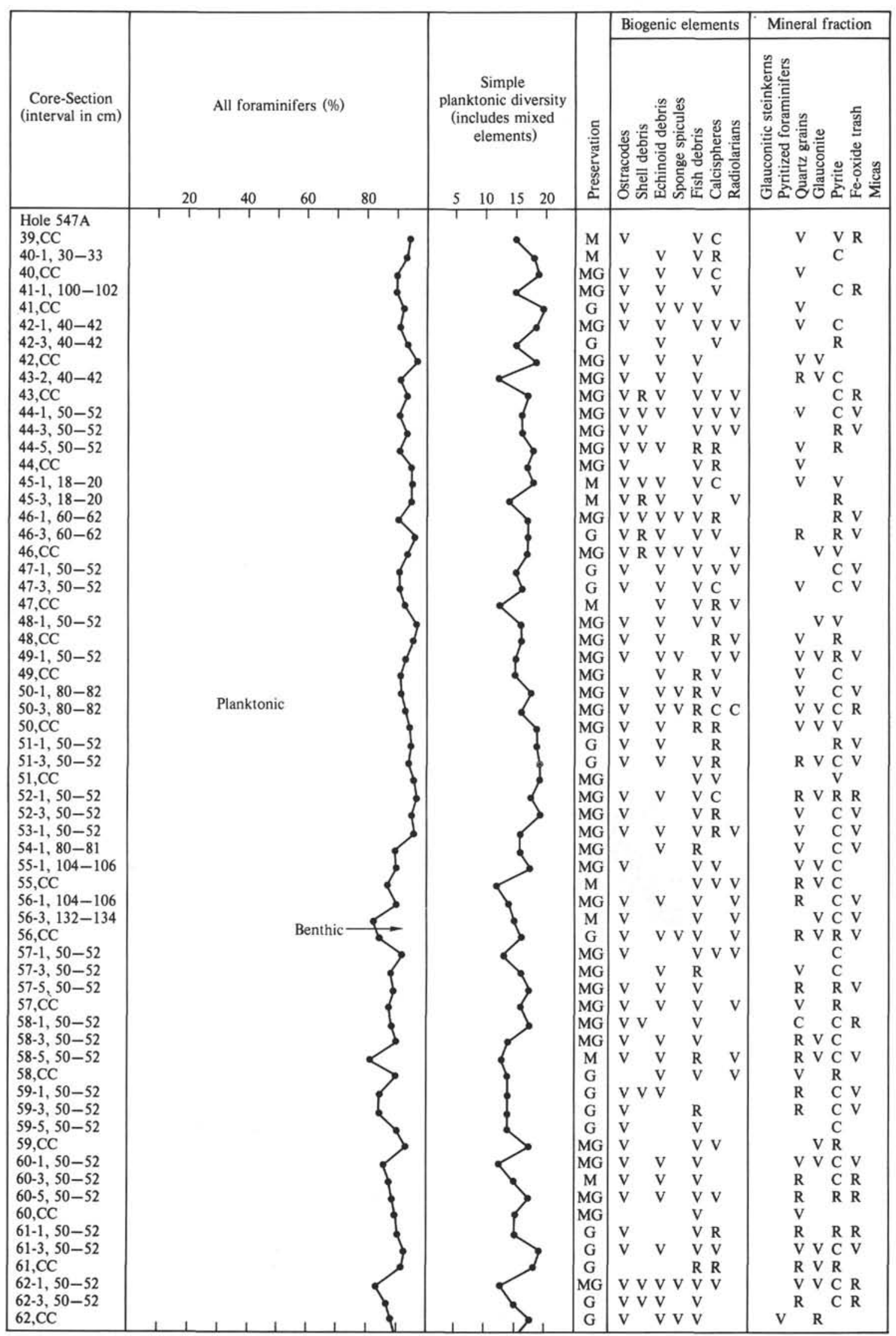

Figure 8. Distribution and character of selected biogenic and lithologic components at Site 547. Explanation as for Figure 7. 


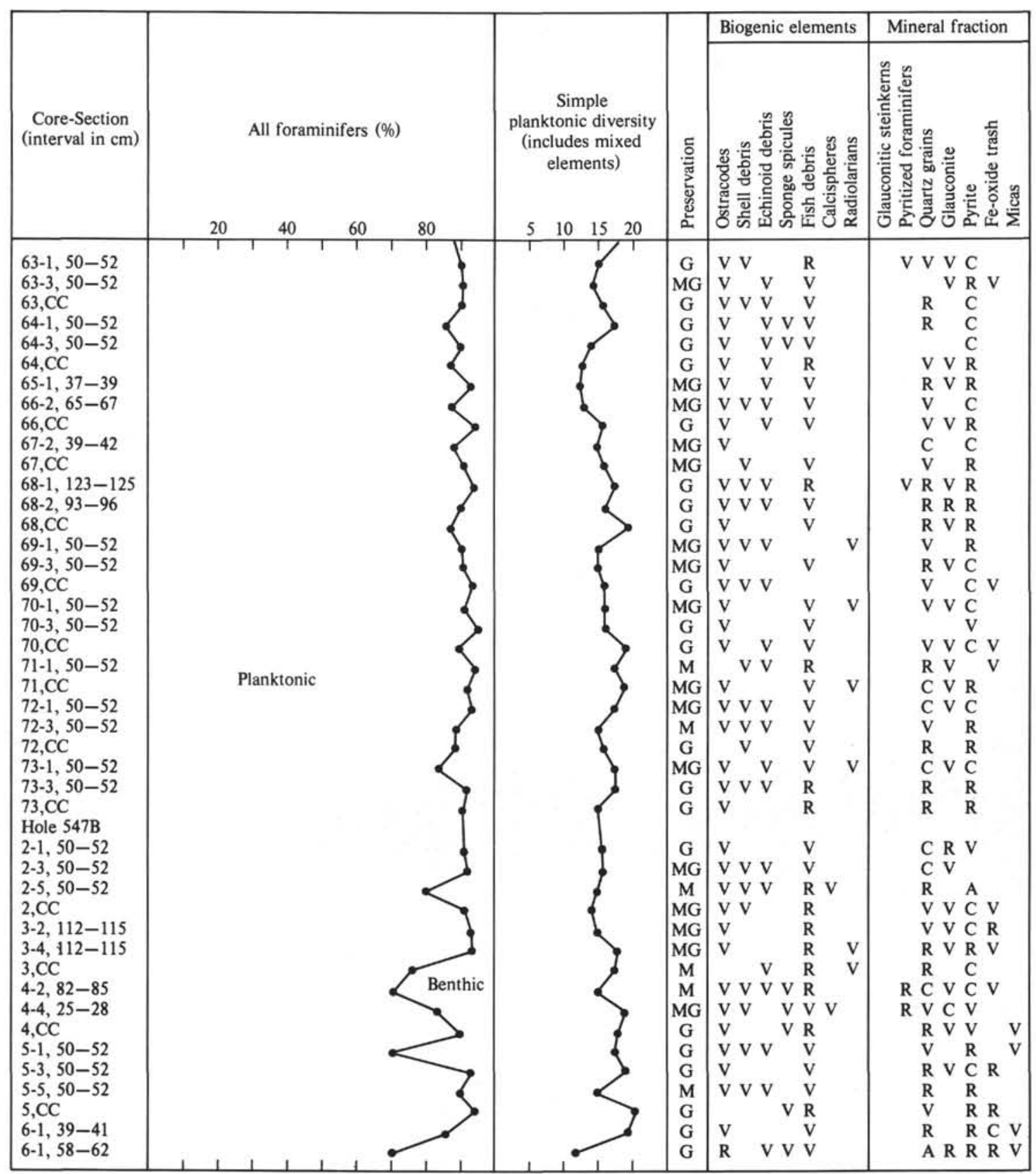

Figure 8. (Continued).

pinged on the seafloor in the vicinity of Site 545 , as recorded by the deposition of thin, organic-carbon-rich, black shales.

Upwelling over Site 545 ended rather abruptly in the early late Albian with a simultaneous reduction in the oxygen minimum zone. This is indicated by the sharp decline and eventual loss of siliceous skeletons in the lower part of Core 40, the significant increase in planktonic foraminiferal diversity and preservation, and a return to normal upper-bathyal planktonic/benthic ratio values (Fig. 7). Although Sites 545 and 547 only-lie some $15 \mathrm{~km}$ apart, there is no record of this upwelling event in the middle Albian sample from Site 547 (Fig. 8).

\section{BIOSTRATIGRAPHY}

The zonal scheme adapted here for the early late Aptian through early late Cenomanian interval (Fig. 10) is based on that of van Hinte (1976) among others. The only new addition to previous schemes is the Planomalina cheniourensis Subzone in the latest Aptian.

Correlation of the mid-Cretaceous sections of Sites 545 and 547 is summarized in Figure 11. A continuous stratigraphic sequence of early late Aptian through middle Albian age is present at Site 545. This interval is absent at Site 547, although a very thin sliver of ?upper middle Albian is present beneath a minor hiatus that oc- 
Time scale

(van Hinte, 1976)

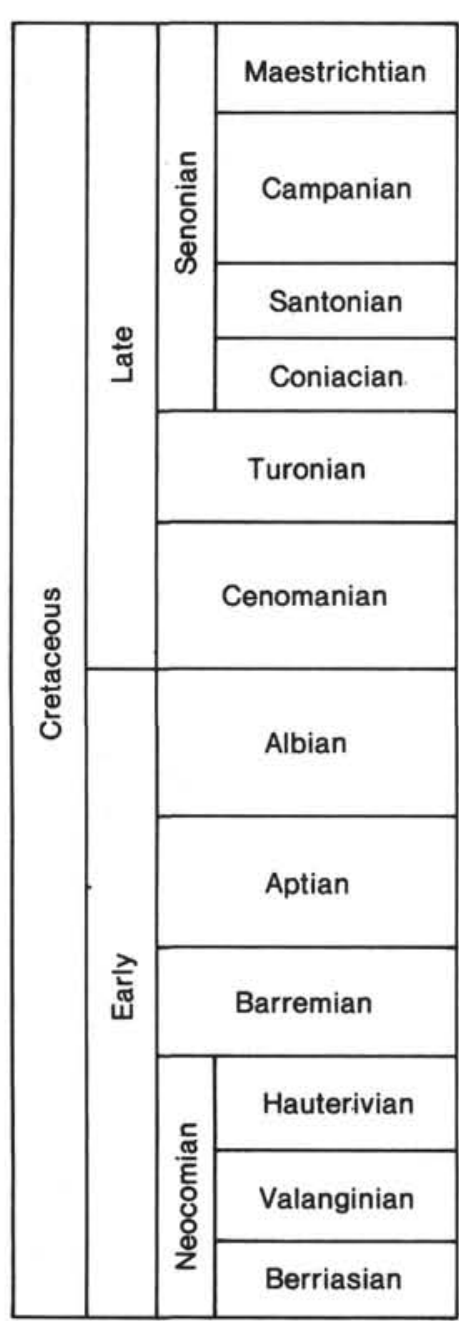

Relative changes of sea level (second-order cycles)

(Vail et al., 1977)

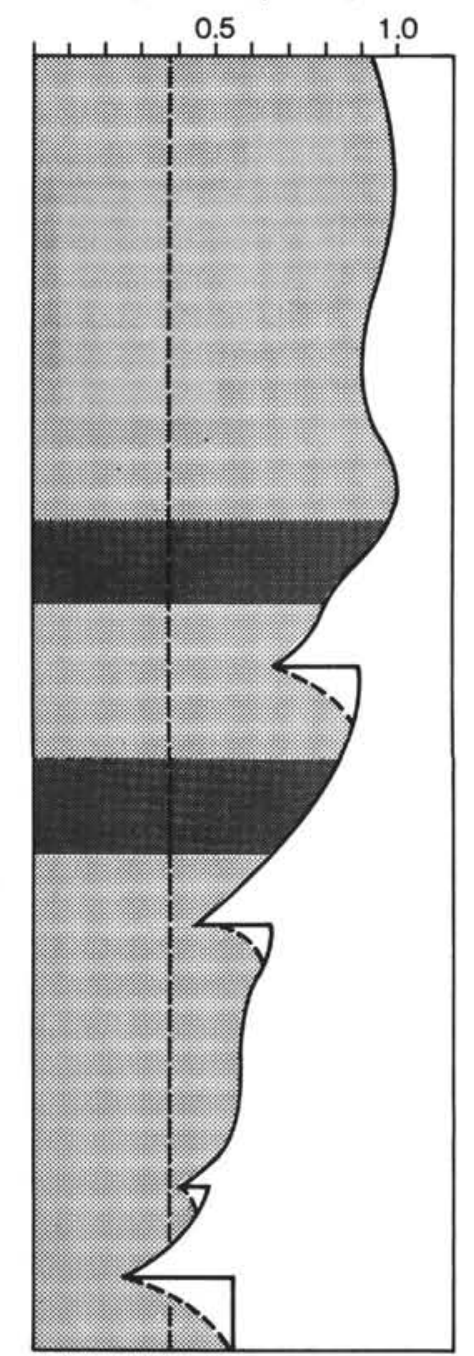

oceanic anoxic events

(Arthur and

Schlanger, 1979)

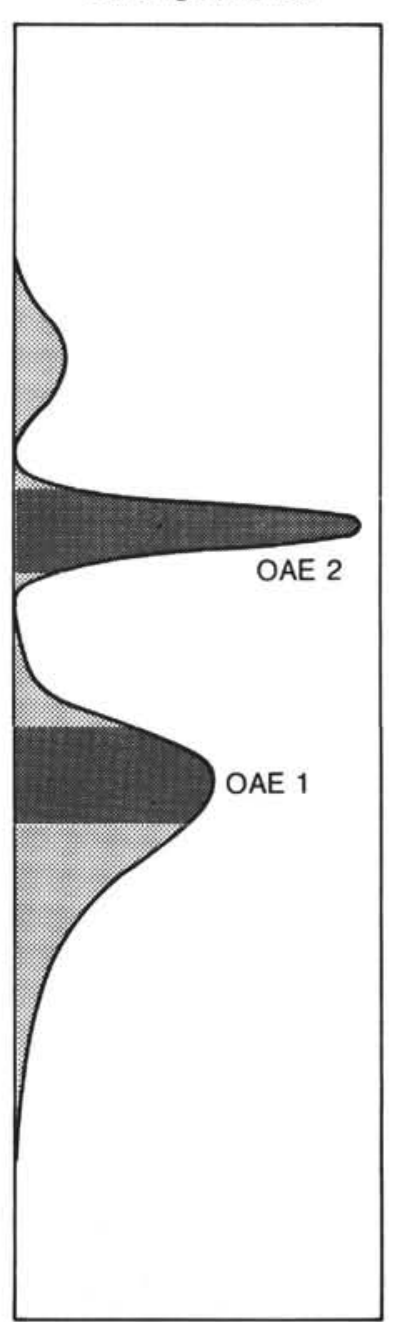

sele and Wiedmann

(1982, 1983);

Butt (1982)
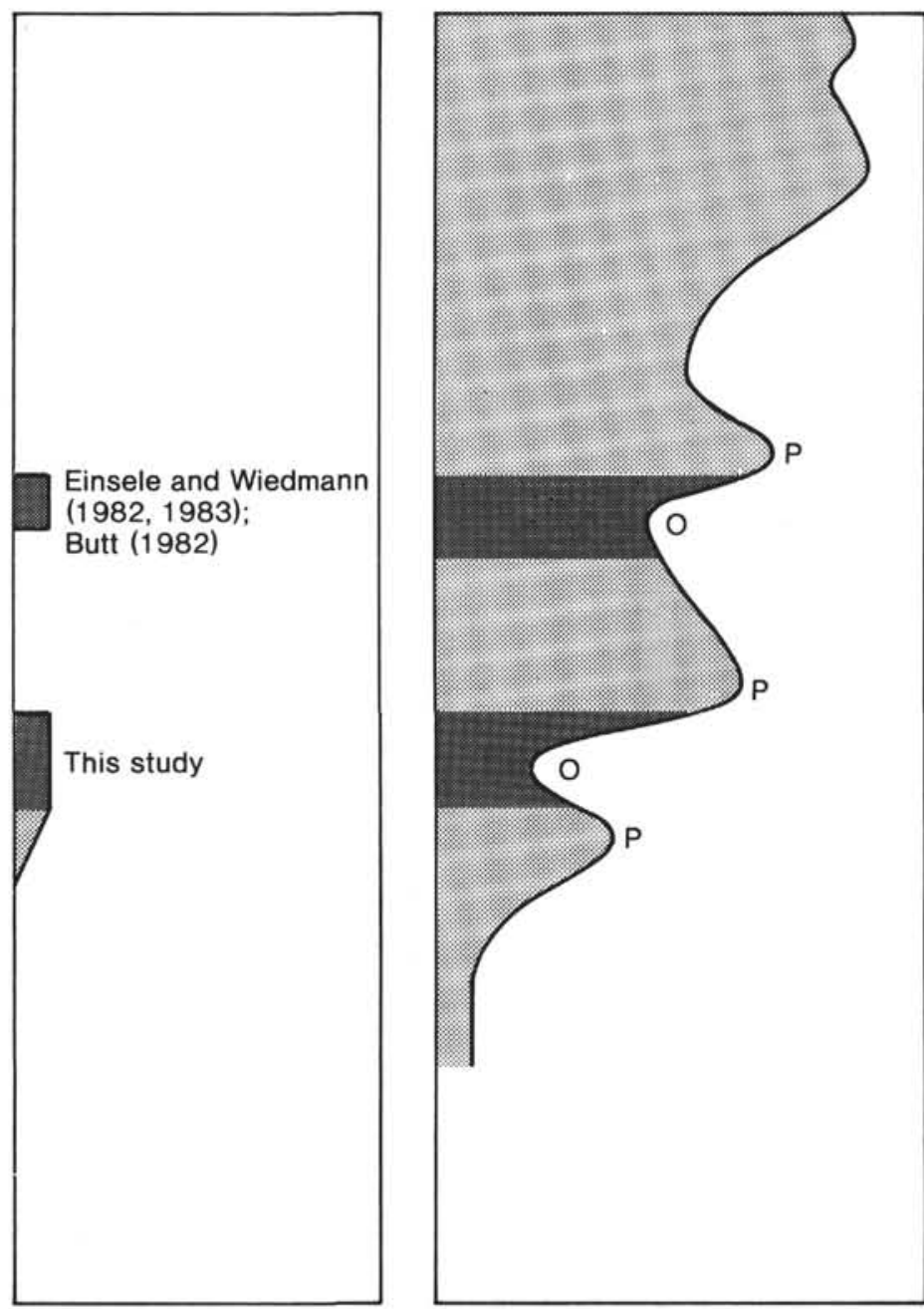

Figure 9. Correlation of global sea level changes, oceanic anoxic events, episodes of upwelling of Northwest Africa, and diversity trends in planktonic foraminifers. $\mathrm{O}=$ oligotaxic; $\mathrm{P}=$ polytaxic. 


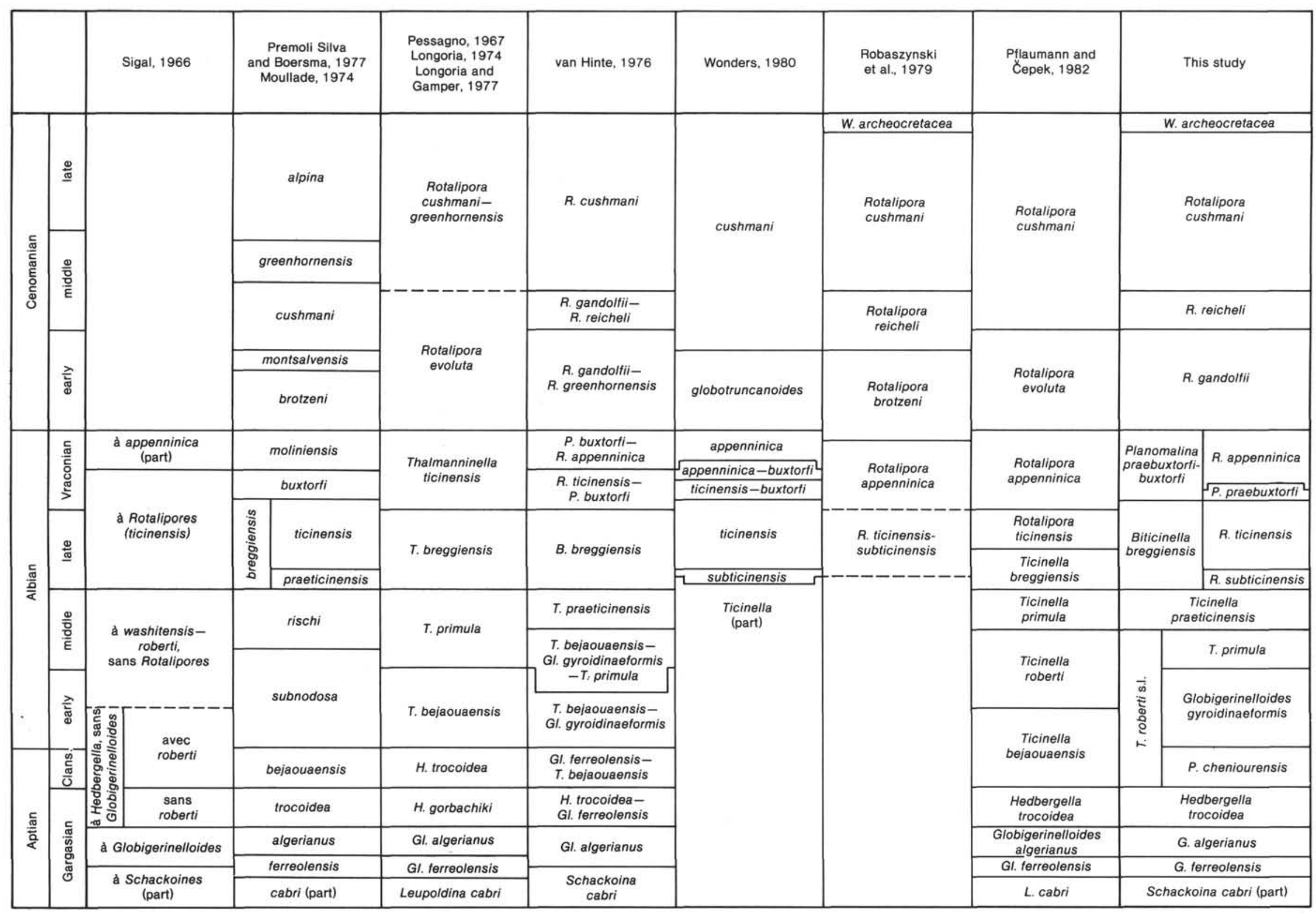

Figure 10. Comparison of previous late Aptian-late Cenomanian zonal schemes with scheme developed for the mid-Cretaceous of DSDP Sites 545 and 547 . Geochronologic framework based on van Hinte (1976). 


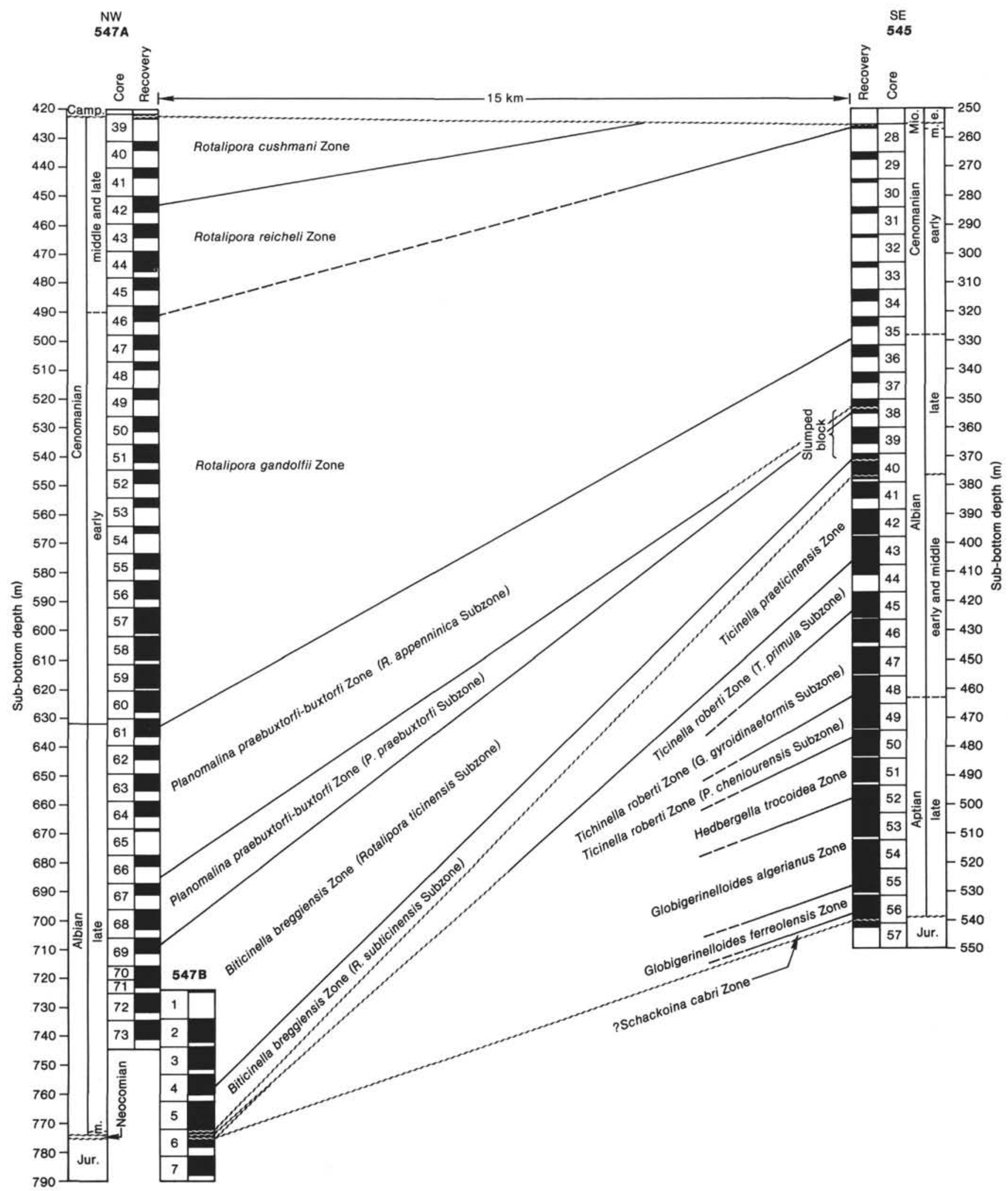

Figure 11. Biostratigraphic correlation between the mid-Cretaceous of DSDP Sites 545 and 547. 
curs between the middle and upper Albian of both sites. Above the diastem, a continuous section of late Albian through early late Cenomanian age at Site 547 contrasts with the thinner, less-complete section of Site 545. Capping the mid-Cretaceous at both sites is a widespread unconformity that is responsible for the paucity of Upper Cretaceous sequences around the North Atlantic (see discussion by Lancelot and Winterer, 1980).

\section{Schackoina cabri Zone}

The equivalent of the Schackoina cabri Zone may be represented by the lower two samples from Site 545. Although the index species is absent, the presence of a single specimen of Globigerinelloides cf. saundersi (Bolli) and the absence of $G$. ferreolensis (Moullade) suggests a latest early Aptian age.

\section{Globigerinelloides ferreolensis Zone}

Definition. Interval from the first occurrence of $G$. ferreolensis (Moullade) to the first appearance of $G$. algerianus Cushman and ten Dam.

Age. Early late Aptian.

Diagnostic taxa. G. ferreolensis, G. blowi s.1. (Bolli), G. aptiense Longoria, Hedbergella delrioensis (Carsey), $H$. aff. sigali Moullade, $H$. aff. trocoidea (Gandolfi), $H$. sp. 1, and Gubkinella graysonensis (Tappan).

Distribution. $545-56-2,76-78 \mathrm{~cm}$ to $545-55-6,40-42$ $\mathrm{cm}$.

\section{Globigerinelloides algerianus Zone}

Definition. Interval representing the total range of $G$. algerianus Cushman and ten Dam.

Age. Late Aptian.

Diagnostic taxa. G. algerianus, G. ferreolensis (Moullade), G. aptiense Longoria, G. blowi s.l. (Bolli), G. barri (Bolli, Loeblich and Tappan), Hedbergella trocoidea (Gandolfi), $H$. aff. trocoidea, $H$. delrioensis (Carsey), $H$. aff. sigali Moullade, $H$. sp. 1 , and Gubkinella graysonensis (Tappan).

Distribution. $545-55-5,4-6 \mathrm{~cm}$ to $545-52-5,93-96 \mathrm{~cm}$.

\section{Hedbergella trocoidea Zone}

Definition. Interval from the last occurrence of $G$. algerianus Cushman and ten Dam to the first appearance of Ticinella roberti s.1. (Gandolfi).

Age. Late Aptian.

Diagnostic taxa. Hedbergella trocoidea, (Gandolfi) H. gorbachikae Longoria, H. delrioensis (Carsey), Globigerinelloides aptiense Longoria, G. blowi s.l. (Bolli), and Gubkinella graysonensis (Tappan).

Distribution. $545-52-3,79-81 \mathrm{~cm}$ to $545-50-3,54-56$ $\mathrm{cm}$.

\section{Ticinella roberti Zone}

Definition. Interval from the first occurrence of $T$. roberti s.l. (Gandolfi) to the first occurrence of $T$. praeticinensis Sigal. Three subzones are recognized.

Age. Latest Aptian to middle Albian.

Distribution. $545-50-1,33-34 \mathrm{~cm}$ to $545-44, \mathrm{CC}$.

\section{Planomalina cheniourensis Subzone}

Definition. Interval from the first appearance of $T i$ cinella roberti (Gandolfi) to the last occurrence of $P$. cheniourensis (Sigal).

Age. Latest Aptian.

Diagnostic taxa. $P$. cheniourensis, $T$. roberti, Hedbergella trocoidea (Gandolfi), $H$. delrioensis (Carsey), and Gubkinella graysonensis (Tappan).

Distribution. $545-50-1,33-34 \mathrm{~cm}$ to $545-48-7,23-25$ $\mathrm{cm}$.

\section{Globigerinelloides gyroidinaeformis Subzone}

Definition. Interval from the last occurrence of Planomalina cheniourensis (Sigal) to the first appearance of Ticinella primula Luterbacher.

Age. Early Albian.

Diagnostic taxa. G. gyroidinaeformis, T. roberti (Gandolfi), Hedbergella trocoidea (Gandolfi), $H$. cf. rischi Moullade, and $H$. delrioensis (Carsey).

Distribution. $545-48-5,45-47 \mathrm{~cm}$ to $545-45, \mathrm{CC}$.

\section{Ticinella primula Subzone}

Definition. Interval from the first appearance of $T$. primula Luterbacher to the first occurrence of $T$. praeticinensis Sigal.

Age. Early middle Albian.

Diagnostic taxa. T. primula, T. roberti (Gandolfi), Globigerinelloides gyroidinaeformis Moullade, Hedbergella cf. rischi Moullade, and $H$. delrioensis (Carsey).

Distribution. $545-45-4,110-115 \mathrm{~cm}$ to $545-44, \mathrm{CC}$.

\section{Ticinella praeticinensis Zone}

Definition. Interval from the first occurrence of $T$. praeticinensis Sigal to the first appearance of Biticinella breggiensis (Gandolfi).

Age. Late middle Albian.

Diagnostic taxa. $T$. praeticinensis, $T$. primula Luterbacher, $T$. roberti (Gandolfi), Globigerinelloides gyroidinaeformis Moullade, Hedbergella cf. rischi Moullade, and $H$. delrioensis (Carsey).

Distribution. 545-44-1, 32-37 $\mathrm{cm}$ to $545-43-1,47-48$ $\mathrm{cm}$. An interval of undifferentiated $T$. praeticinensis and Biticinella breggiensis Zones occurs from 545-42-5, 93$95 \mathrm{~cm}$ to $545-40-6$ (bottom). A single sample from 547B$6-1,58-62 \mathrm{~cm}$ is probably equivalent to the $T$. praeticinensis Zone.

\section{Biticinella breggiensis Zone}

Definition. Interval from the first appearance of $\boldsymbol{B}$. breggiensis (Gandolfi) to the first occurrence of Planomalina praebuxtorfi Wonders. Two subzones are recognized.

Age. Early late Albian.

Distribution. $545-40-5,8-10 \mathrm{~cm}$ to $545-38, \mathrm{CC}$ and $547 \mathrm{~B}-6-1,39-41 \mathrm{~cm}$ to $547 \mathrm{~A}-69-3,50-52 \mathrm{~cm}$.

\section{Rotalipora subticinensis Subzone}

Definition. Interval from the first appearance of Biticinella breggiensis (Gandolfi) to the last occurrence of $R$. subticinensis (Gandolfi). 
Age. Early late Albian.

Diagnostic taxa. $R$. subticinensis, $R$. ticinensis (Gandolfi), Ticinella primula Luterbacher, $T$. raynaudi s.1. Sigal, T. madecassiana Sigal, T. roberti (Gandolfi), Globigerinelloides bentonensis (Morrow), G. ultramicrus (Subbotina), Clavihedbergella subcretacea (Tappan), C. moremani (Cushman), C. simplex (Morrow), Hedbergella delrioensis (Carsey), H. planispira (Tappan), and $H$. simplicissima (Magné and Sigal).

Distribution. $545-40-5,8-10 \mathrm{~cm}$ to $545-40-3,8-10 \mathrm{~cm}$ and $547 \mathrm{~B}-6-1,39-41 \mathrm{~cm}$ to $547 \mathrm{~B}-4-4,25-28 \mathrm{~cm}$.

\section{Rotalipora ticinensis Subzone}

Definition. Interval from the last occurrence of $R$. subticinensis (Gandolfi) to the first occurrence of Planomalina praebuxtorfi Wonders.

Age. Late Albian.

Diagnostic taxa. Characterized by the same basic taxa as in the Ticinella subticinensis Subzone but with the addition of $R$. praebalernaensis Sigal as a diagnostic taxon.

Distribution. $545-39, \mathrm{CC}$ to $545-38, \mathrm{CC}$ and $547 \mathrm{~B}-4-2$, $82-85 \mathrm{~cm}$ to $547 \mathrm{~A}-69-3,50-52 \mathrm{~cm}$.

\section{Planomalina praebuxtorfi-buxtorfi Zone}

Definition. Interval from the first occurrence of $P$. praebuxtorfi Wonders to the last occurrence of $P$. buxtorfi (Gandolfi). Two subzones are recognized.

Age. Latest Albian (Vraconian).

Distribution. $545-38-3,90-92 \mathrm{~cm}$ to $545-36-1,145-$ $150 \mathrm{~cm}$ and $547 \mathrm{~A}-69-1,50-52 \mathrm{~cm}$ to $547 \mathrm{~A}-61-3,50-52 \mathrm{~cm}$.

\section{Planomalina praebuxtorfi Subzone}

Definition. Interval representing the total range of $P$. praebuxtorfi Wonders.

Age. Early Vraconian.

Diagnostic taxa. P. praebuxtorfi, $P$. buxtorfi (Gandolfi), Rotalipora appenninica (Renz), $R$. praebalernaensis Sigal, Ticinella madecassiana Sigal, Globigerinelloides bentonensis (Morrow), G. ultramicrus (Subbotina), Hedbergella paradubia (Sigal), $H$. simplicissima (Magné and Sigal), $H$. delrioensis (Carsey), $H$. planispira (Tappan), and Clavihedbergella simplex (Morrow).

Distribution. 545-38-3, 90-92 $\mathrm{cm}$ and 547A-69-1, $50-52 \mathrm{~cm}$ to $547 \mathrm{~A}-67-2,39-42 \mathrm{~cm}$.

\section{Rotalipora appenninica Subzone}

Definition. Interval from the last occurrence of Planomalina praebuxtorfi Wonders to the last occurrence of $P$. buxtorfi (Gandolfi).

Age. Latest Albian.

Diagnostic taxa. The assemblages are essentially the same as in the Planomalina praebuxtorfi Subzone but important additions include Rotalipora gandolfii Luterbacher and Premoli Silva, Praeglobotruncana delrioensis (Plummer), P. stephani (Gandolfi), Hedbergella libyca Barr, Heterohelix moremani (Cushman), Guembelitria cenomana (Keller), and Schackoina spp., whereas Ticinella madecassiana Sigal and Rotalipora praebalernaensis Sigal drop out of the fauna.

Distribution. 545-38-1, 90-92 $\mathrm{cm}$ to $545-36-1,145-$ $150 \mathrm{~cm}$ and $547 \mathrm{~A}-66, \mathrm{CC}$ to $547 \mathrm{~A}-61-3,50-52 \mathrm{~cm}$.

\section{Rotalipora gandolfii Zone}

Definition. Interval from the last occurrence of Planomalina buxtorfi (Gandolfi) to the first appearance of $R$. reicheli (Mornod).

Age. Early Cenomanian.

Diagnostic taxa. Hedbergella libyca Barr is important in the lower part whereas $R$. micheli (Sacal and Debourle), $R$. aff. cushmani (Morrow) and $R$. greenhornensis (Morrow) become important in the mid and upper parts of the $R$. gandolfii Zone. Taxa that range throughout the zone include $R$. gandolfii (Luterbacher and Premoli Silva), R. appenninica (Renz), Praeglobotruncana delrioensis (Plummer), P. stephani (Gandolfi), Globigerinelloides bentonensis (Morrow), G. ultramicrus (Subbotina), Clavihedbergella simplex (Morrow), Hedbergella delrioensis (Carsey), H. planispira (Tappan), Heterohelix moremani (Cushman), Guembelitria cenomana (Keller), and Schackoina spp.

Distribution. 545-35, CC to 545-28, CC and 547A-61-1, $50-52 \mathrm{~cm}$ to approximately $547 \mathrm{~A}-46-3,60-62 \mathrm{~cm}$, based on correlation with calcareous nannofossil data (Wiegand, this vol.)

\section{Rotalipora reicheli Zone}

Definition. Interval from the first appearance of $R$. reicheli (Mornod) to the first appearance of $R$. cushmani (Morrow).

Age. Middle Cenomanian.

Discussion. Because $R$. reicheli is absent in the Site 547 samples, the base of the $R$. reicheli Zone is correlated with the base of the Cruciellipsis chiasta Subzone (Lithraphidites acutum Zone), (Wiegand, this vol.), which roughly corresponds with the first appearance of $R$. reicheli at Site 545.

Diagnostic taxa. Composition of the assemblages as for the upper part of the $R$. gandolfii Zone with the important addition of the index species and the loss of $R$. appenninica (Renz).

Distribution. $545-28-1,47-49 \mathrm{~cm}$ to $545-28-1,10-12 \mathrm{~cm}$ and approximately $547 \mathrm{~A}-46-1,60-62 \mathrm{~cm}$ to $547 \mathrm{~A}-42-3$, $40-42 \mathrm{~cm}$.

\section{Rotalipora cushmani Zone}

Definition. Interval representing the total range of $R$. cushmani (Morrow). Only the lowermost part of this zone was recovered at Site 547.

Age. Late Cenomanian.

Diagnostic taxa. $R$. cushmani, $R$. greenhornensis (Morrow), Praeglobotruncana delrioensis (Plummer), P. stephani (Gandolfi), Globigerinelloides bentonensis (Morrow), G. ultramicrus (Subbotina), Clavihedbergella simplex (Morrow), Hedbergella delrioensis (Carsey), $H$. planispira (Tappan), Heterohelix moremani (Cushman), Guembelitria cenomana (Keller), and Schackoina spp.

Distribution. 547A-42-1, 40-42 cm to 547A-39,CC.

\section{TAXONOMIC NOTES}

All species encountered in this study are presented below. Synonomies are limited to the original reference plus one or two additional references whose synonomy lists and species concepts are followed here. Brief discussions are included, where appropriate, to review literature controversies and explain how the author differentiates one form 
from morphologically similar or related forms. For detailed descriptions the reader is referred to the references listed in the synonomies. Planktonic foraminiferal distributions through the mid-Cretaceous sections of DSDP Sites 545 and 547 are shown in Tables 1 and 2.

Gubkinella graysonensis (Tappan)

$$
\text { (Pl. 1, Figs. 2-3) }
$$

Globigerina graysonensis Tappan, 1940, p. 122, pl. 19, figs. 15-17. Gubkinella graysonensis (Tappan). Longoria, 1974, p. 50, pl. 1, figs. 1-12.

Occurrence. This distinctive species is particularly common in the uppermost Aptian to mid Albian of Site 545 but also occurs throughout the upper Albian and Cenomanian.

\section{Guembelitria cenomana (Keller)}

$$
\text { (Pl. 11, Fig. 12) }
$$

Guembelina cenomana Keller, 1935, pp. 547-548, pl. 2, figs. 13, 14. Masters, 1977 , pp. $481-482$, pl. 27 , figs. 1,3 .

Occurrence. Rare to common in the upper Albian and lower Cenomanian of Sites 545 and 547 (Planomalina praebuxtorfi-buxtorfi Zone to Rotalipora gandolfii Zone).

\section{Heterohelix moremani (Cushman)}

$$
\text { (Pl. 10, Fig. 12) }
$$

Guembelina moremani Cushman, 1938, p. 10, pl. 2, figs. 1a-3.

Heterohelix moremani (Cushman). Pessagno, 1967, p. 260-261, pl. 48, figs. 10,11 ; pl. 89 , figs. $1-2$.

Occurrence. Rare to common from the uppermost Albian (Planomalina praebuxtorfi-buxtorfi Zone) through Cenomanian of Sites 545 and 547.

\section{Globigerinelloides algerianus Cushman and ten Dam}

$$
\text { (Pl. 2, Figs. 5-8) }
$$

Globigerinelloides algeriana Cushman and ten Dam, 1948, p. 42, pl. 8, figs. 4-6.

Globigerinelloides algerianus Cushman and ten Dam. Longoria, 1974, pp. 77-79, pl. 6, figs. 1-18.

Discussion. This distinctive species demonstrates considerable morphologic variability especially in breadth (thickness) of the test and the degree to which the test becomes evolute. Stratigraphically older specimens tend to be gradational with $G$. ferreolensis (Moullade).

Occurrence. Rare throughout the upper Aptian $G$. algerianus Zone of Site 545. Recycled specimens occur sporadically as high as the lower Cenomanian.

\section{Globigerinelloides aptiense Longoria}

$$
\text { (P1. 1, Figs. 9-11) }
$$

Globigerinelloides aptiense Longoria, 1974, pp. 79-80, pl. 4, figs. 9, 10 ; pl. 8, figs. 4-6, 17, 18 .

Discussion. G. aptiense, as reported here, extends through a much longer range than originally described by Longoria. This observation may, however, be an artifact of recycling. $G$. aptiense differs from $G$. ferreolensis (Moullade) in having 5-6-1/2 chambers in the final whorl rather than 7 to 9 .

Occurrence. A common species in the upper Aptian to lowermost Albian ( $G$. ferreolensis Zone to lower Ticinella roberti s.l. Zone), then becoming rare into the middle Albian of Site 545.

\section{Globigerinelloides barri (Bolli, Loeblich, and Tappan)}

$$
\text { (Pl. 2, Figs. 1-4) }
$$

Biglobigerinella barri Bolli, Loeblich, and Tappan, 1957, p. 25, pl. 1 , figs. 13-18.

Globigerinelloides barri (Bolli, Loeblich, and Tappan). Longoria, 1974, pp. 80-82, pl. 4, figs. $1-3,8,14$; pl. 5, figs. 9-16; pl. 27, fig. 19. Discussion. G. barri differs from both $G$. ferreolensis (Moullade) and $G$. algerianus Cushman and ten Dam in being circular in outline rather than elliptical and having a broader (thicker) test.

Occurrence. A rare species at Site 545, where it is restricted to the upper Aptian G. algerianus Zone.

\section{Globigerinelloides bentonensis (Morrow)}

(Pl. 10, Figs. 5-11)

Anomalina bentonensis Morrow, 1934, p. 201, pl. 30, fig. 4.

Planomalina caseyi Bolli, Loeblich, and Tappan, 1957, p. 24, pl. 1, figs. 4-5.

Globigerinelloides eaglefordensis (Moreman). Loeblich and Tappan, 1961 , p. 268, pl. 2, figs. 3-7.

Globigerinelloides bentonensis (Morrow). Eicher and Worstell, 1970, p. 297 , pl. 8 , figs. 17,19 ; pl. 9, fig. 3 .

Globigerinelloides cushmani (Tappan). Masters, 1977, p. 408, pl. 10, fig. 4 ; pl. 11, figs. 1-2.

Discussion. G. bentonensis (Morrow) is a common component of the Cenomanian planktonic assemblages from the Western Interior, U.S.A., where it was first described. Typical specimens are illustrated by Eicher and Worstell (1970). The specimens illustrated by Bolli, Loeblich, and Tappan (1957) and described as Planomalina caseyi are identical to $G$. bentonensis from the type locality in Kansas. Smal specimens can be confused with $G$. ultramicrus (Subbotina). However, G. bentonensis includes larger forms with more inflated and more rapidly increasing chambers.

Occurrence. Rare specimens referable to $G$. bentonensis are first observed in the ?middle to upper Albian of Site 545. A common species throughout the upper Albian and Cenomanian of Sites 545 and 547.

\section{Globigerinelloides blowi s.I. (Bolli)}

(PI. 1, Figs. 4-8)

Planomalina blowi Bolli, 1959, p. 260, pl. 20, figs. 2, 3 .

Planomalina maridalensis Bolli, 1959, p. 261, pl. 20, figs. 4-6. Globigerinella duboisi Chevalier, 1961, p. 33, pl. 1, figs. 14-18.

Globigerinella gottisi Chevalier, 1961, pp. 33-34, pl. 1, figs. 9-11, 13 (not fig. 12).

Globigerinelloides blowi (Bolli). Masters, 1977, pp. 406-408, pl. 11, fig. 3 .

Discussion. A somewhat variable species group with 4 to 5 chambers in the final whorl. There appears to be a continuous range of variation in chamber shape and width from ovoid to subspherical shapes representing the $G$. blowi/maridalensis (Bolli) morphotype suite to subclavate (elongate) shapes representing the G. duboisi/gottis (Chevalier) morphotype suite.

Occurrence. Particularly common in the upper Aptian of Site 545, then becomes rare in the lower and middle Albian (to within the Ticinella praeticinensis Zone). These latter occurrence may be recycled.

\section{Globigerinelloides ferreolensis (Moullade)}

$$
\text { (Pl. 2, Figs. 9-12) }
$$

Biticinella ferreolensis Moullade, 1961, p. 14, pl. 1, figs. 1-5. Globigerinelloides ferreolensis (Moullade). Longoria, 1974, pp. 84-85, pl. 5 , figs. 7,8 ; pl. 8 , figs. $1-3,8-15 ;$ pl. 14 , figs. $7-8$; pl. 27 , figs. $3,5,12$.

Discussion. $G$. ferreolensis is distinguished from $G$. aptiense Longoria in having 7-9 chambers in the final whorl rather than 5-61/2.

Occurrence. Typically a rare but persistent species through the upper Aptian of Site 545 ( $G$. ferreolensis Zone through Hedbergella trocoidea Zone and occasionally present in the lower Ticinella roberti s.l. Zone).

\section{Globigerinelloides gyroidinaeformis Moullade}

$$
\text { (Pl. 7, Figs. 7-8) }
$$

"Globigerinelloides" gyroidinaeformis Moullade, 1966, pp. 128-129, pl. 9, figs. 16-22.

Occurrence. This robust species is rare in the lower and middle Albian of Site 545 ( $G$. gyroidinaeformis Subzone to Ticinella praeticinensis Zone).

\section{Globigerinelloides saundersi (Bolli)}

Planomalina saundersi Bolli, 1959, p. 262, pl. 20, figs. 9-11. Globigerinelloides saundersi (Bolli). Longoria, 1974, p. 88, pl. 3, figs. 2, 6-12; pl. 9, figs. 8, 9. 
Table 1. Distribution and relative abundance of mid-Cretaceous planktonic foraminifers at Site 545 .

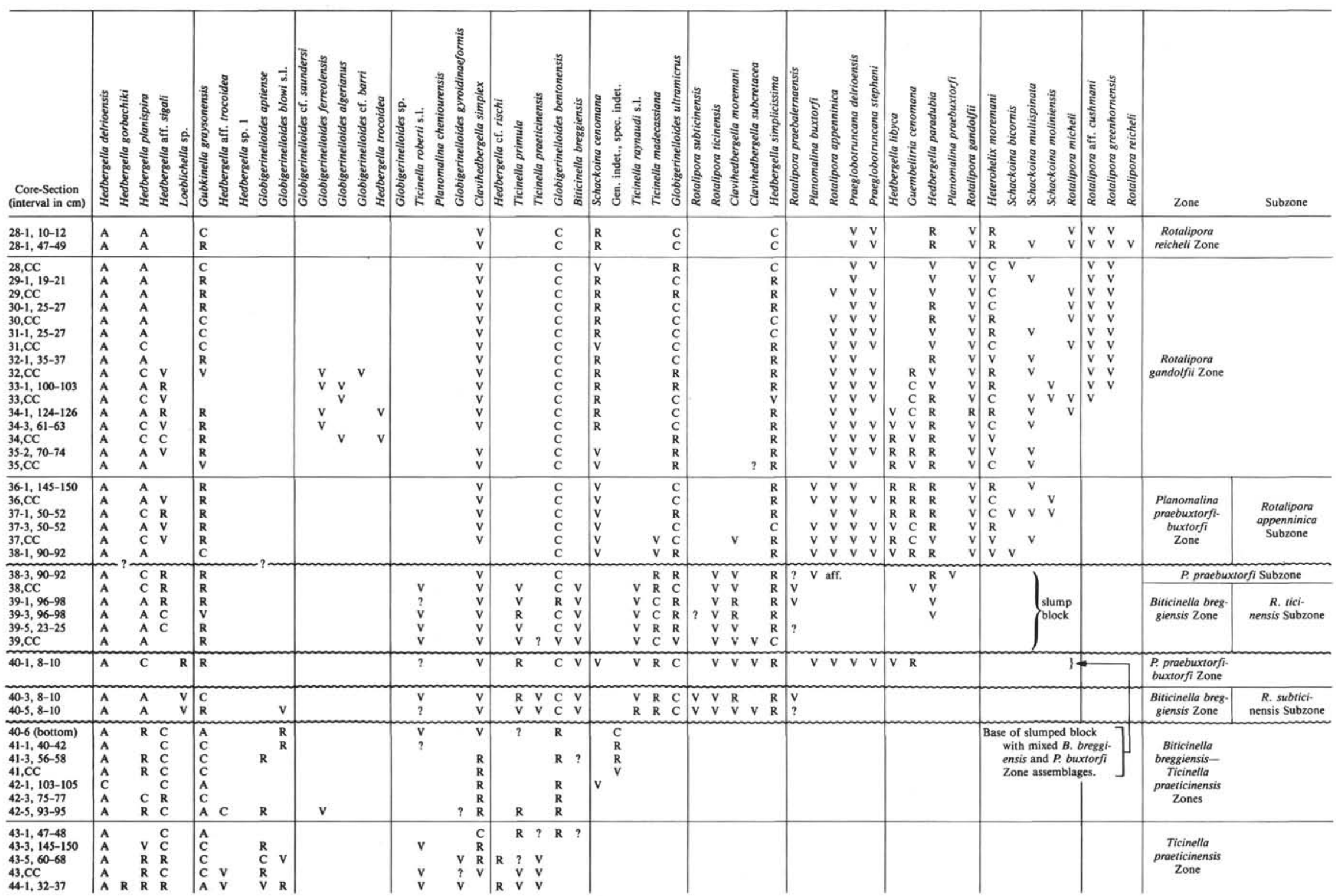




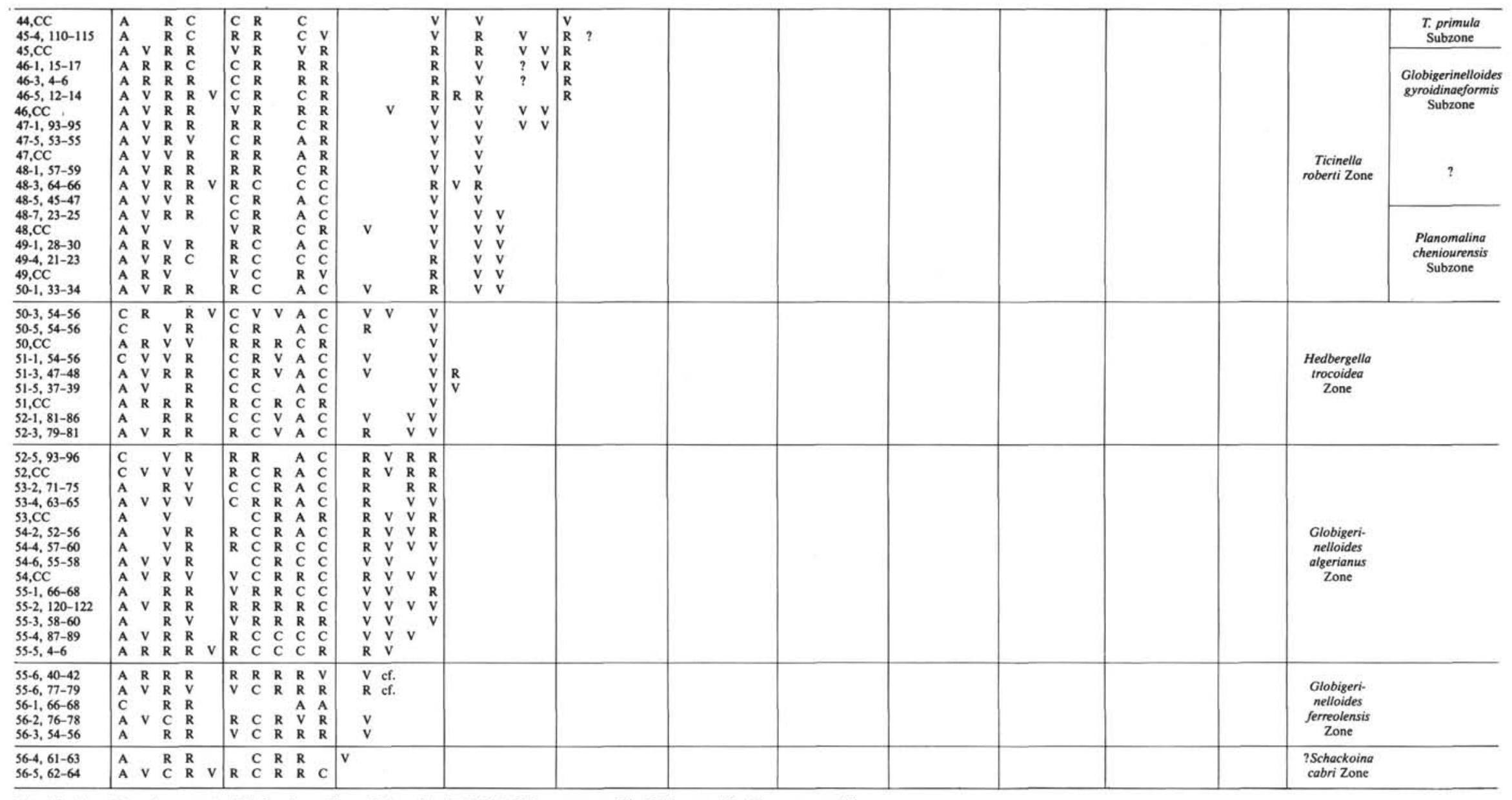

Note: Based on 300-specimen counts of the fraction $>63 \mu \mathrm{m} .25 \%=$ abundant $(\mathrm{A}), 5-25 \%=$ common (C), $1-5 \%=$ rare (R), $1 \%=$ very rare (V). 


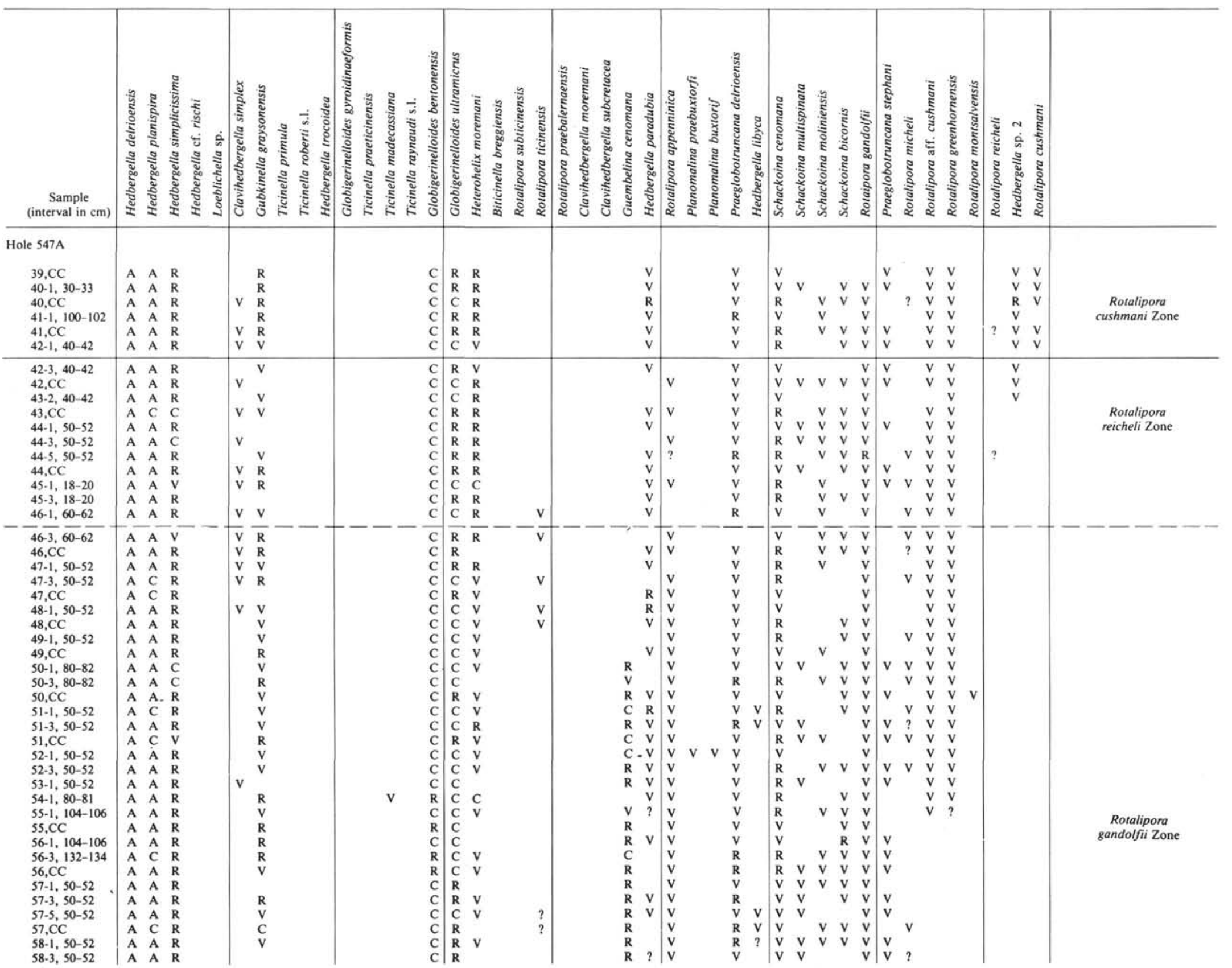




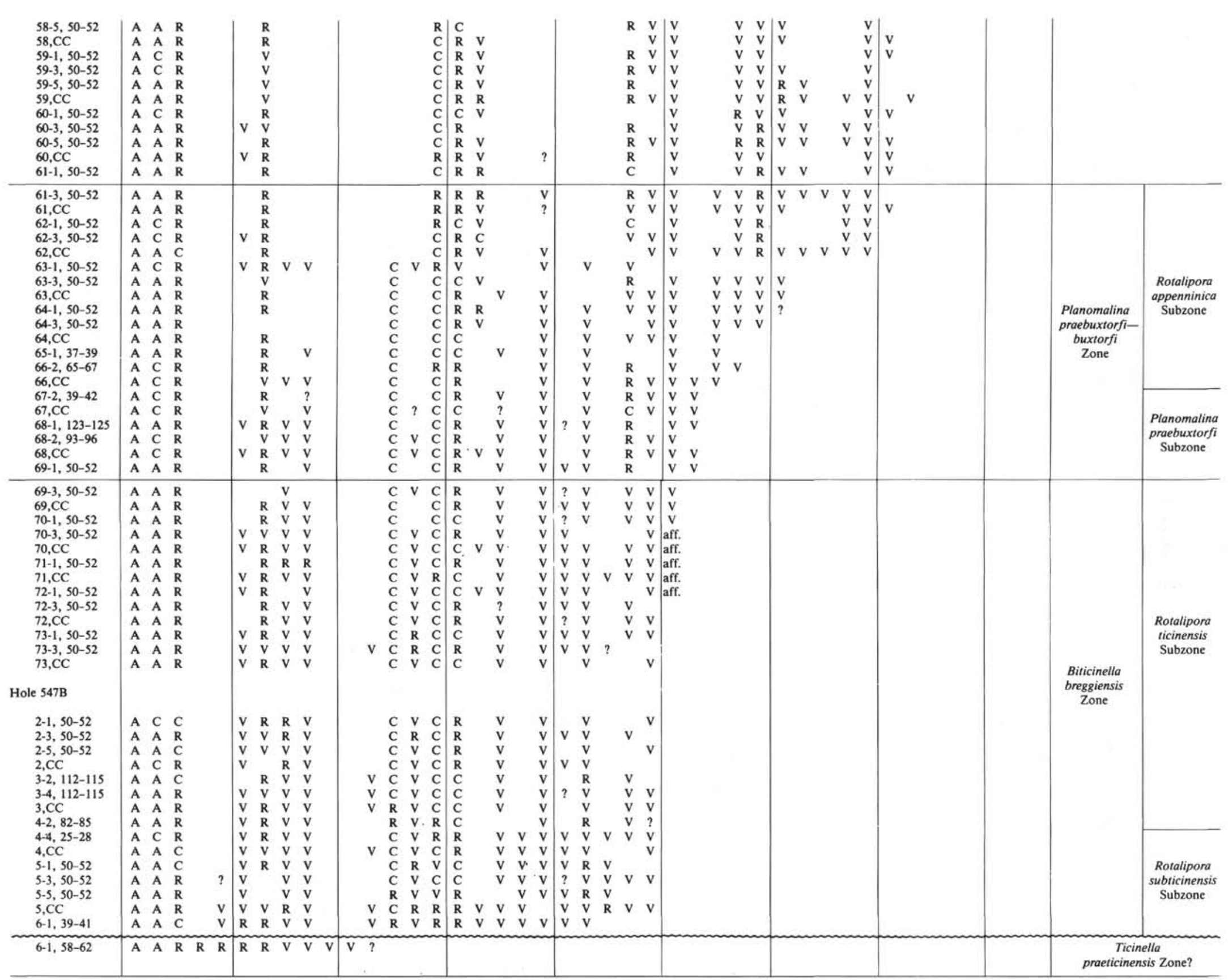

Note: Based on 300-specimen counts of the fraction $>63 \mu \mathrm{m} .25 \%=$ abundant (A), $5-25 \%=$ common $(\mathrm{C}), 1-5 \%=$ rare (R), $1 \%=$ very rare (V). 


\section{R. M. LECKIE}

Occurrence. A single specimen is recorded from $545-56-4,61-63 \mathrm{~cm}$ (?lower Aptian).

\section{Globigerinelloides ultramicrus (Subbotina)}

(Pl. 11, Figs. 10-11)

Globigerinella ultramicra Subbotina, 1949, p. 33, pl. 2, figs. 17, 18. Globigerinelloides caseyi (Bolli, Loeblich, and Tappan). Eicher and Worstell, 1970, p. 297, pl. 8, figs. 11, 15, 16.

Globigerinelloides ultramicra (Subbotina). Masters, 1977, p. 413, pl. 12, figs. 3-5.

Discussion. This species is distinguished by its small, compressed test. It superficially resembles Hedbergella planispira (Tappan) and specimens typically have to be flipped over to confirm its planispiral, biumbilicate form.

Occurrence. A common taxon throughout the upper Albian and Cenomanian of Sites 545 and 547.

\section{Planomalina buxtorfi (Gandolfi)}

(Pl. 10, Figs. 3-4)

Planulina buxtorfi Gandolfi, 1942, p. 103, pl. 3, fig. 7; pl. 5, figs. 3-6; pl. 6 , figs. $1-3$; pl. 8 , fig. 8 ; pl. 9, fig. 2 ; pl. 12, fig. 2 ; pl. 13, figs. $13,15$.

Planomalina buxtorfi (Gandolfi). Wonders, 1975, pp. 91-92, pl. 1, fig. 4; text-figs. 3a-4b.

Occurrence. The range of $P$. buxtorfi defines the uppermost zone of the Albian.

\section{Planomalina cheniourensis (Sigal)}

(PI. 4, Figs. 1-4)

Planulina cheniourensis Sigal, 1952, p. 21, pl. 17.

Planomalina cheniourensis (Sigal). Moullade, 1966, pp. 130-131, textfig. 3. Dupeuble, 1979, pl. 2, figs. 10, 11 .

Discussion. This species basically differs from Globigerinelloides algerianus Cushman and ten Dam in possessing a keel along much of its periphery. Some specimens are similar in appearance to the unrelated late Albian Planomalina buxtorfi (Gandolfi) (see discussion by Moullade, 1966).

Occurrence. In the present study, $P$. cheniourensis is restricted to the $P$. cheniourensis Subzone (uppermost Aptian) of Site 545 although some workers recognize an earlier first occurrence whereas others recognize a range into the early Albian.

\section{Planomalina praebuxtorfi Wonders}

(Pl. 10, Figs. 1-2)

Planomalina praebuxtorfi Wonders, 1975, pp. 90-91, pl. 1, figs. 1a-c, 2a-c; text-fig. 4: 2a, b.

Discussion. The Globigerinelloides caseyi $(=G$. bentonensis $)-P l a-$ nomalina buxtorfi lineage proposed by Wonders (1975) is beautifully represented in the Leg 79 material. A transitional specimen between $G$. bentonensis (Morrow) and P. praebuxtorfi is illustrated on Pl. 10, Figs. 5-6.

Occurrence. $P$. praebuxtorfi is confined to the lowermost $P$. praebuxtorfi-buxtorfi Zone (P. praebuxtorfi Subzone, upper Albian).

\section{Schackoina bicornis Reichel}

(P1. 9, Figs. 10-11)

Schackoina cenomana bicornis Reichel, 1948, pp. 401-402, text-figs. $4 a-g, 6(4), 7(4), 8 b, 9 a-g, 10(6,8)$.

Schackoina bicornis Reichel. Masters, 1977, pp. 429-430, pl. 15, figs. 3-4.

Occurrence. A rare species in the upper Albian (Planomalina praebuxtorfi-buxtorfi Zone) and Cenomanian of Sites 545 and 547.

\section{Schackoina cenomana (Schacko)}

$$
\text { (P1. 9, Figs. 5, 9) }
$$

Siderolina cenomana Schacko, 1897, p. 166, pl. 4, figs. 3-5.

Schackoina cenomana (Schacko). Masters, 1977, pp. 430-432, pl. 16, figs. 1-2.

Occurrence. A persistent taxon from the upper Albian (Planomalina praebuxtorfi-buxtorfi Zone) through the Cenomanian.

\section{Schackoina moliniensis Reichel}

(P1. 9, Fig. 13)

Schackoina moliniensis Reichel, 1948, pp. 402, 404; text-figs. 5a-d, 6(5), 7(5), 8c, 10(13).

Schackoina moliniensis Reichel. Masters, 1977, p. 434, pl. 17, fig. 1. Caron, 1978, pl. 8, figs. 10-11.

Occurrence. A rare species in the upper Albian (Planomalina praebuxtorfi-buxtorfi Zone) and Cenomanian of Sites 545 and 547.

\section{Schackoina multispinata (Cushman and Wickenden)}

(Pl. 9, Fig. 12)

Hantkenina multispinata Cushman and Wickenden, 1930, pp. 40-43, pl. 6, figs. 4-6 (not 4a-c).

Schackoina multispinata (Cushman and Wickenden). Masters, 1977, pp. $434-435$, pl. 16, figs. 4,6 ; pl. 17, fig. 2 .

Occurrence. Persistent from the Planomalina praebuxtorfi-buxtorfi Zone (late Albian) through the Cenomanian.

\section{Hedbergella delrioensis (Carsey) \\ (Pl. 1, Fig. 12; Pl. 9, Figs. 1-4, 8)}

Globigerina cretacea d'Orbigny var. delrioensis Carsey, 1926, p. 43. Globigerina infracretacea Glaessner, 1937, p. 28, text-fig. 1.

Hedbergella delrioensis (Carsey). Loeblich and Tappan, 1961, p. 275, pl. 2, figs. 11-13.

Discussion. $H$. delrioensis is a moderately variable species characterized by its flat or nearly flat dorsal side and 4-1/2-5-1/2 chambers in the final whorl. Variation is represented by the degree of chamber enlargement as added to the whorl, development of an apertural lip, and surface texture; the late Albian-Cenomanian specimens tend to be slightly larger and more pustulose whereas the late Aptian-middle Albian specimens tend to be smoother, smaller, and possess a less pronounced apertural lip. Such variability can probably be explained as ecophenotypic, and a consistent differentiation between $H$. delrioensis and Aptian-Albian $H$. infracretacea (Glaessner) could not established in this study. Hermes (1969) has suggested that $H$. infracretacea may actually be a chronosubspecies of $H$. delrioensis.

Occurrence. $H$. delrioensis is the most abundant and persistent species throughout the upper Aptian-Cenomanian of Sites 545 and 547.

\section{Hedbergella gorbachikae Longoria}

(Pl. 4, Figs. 9-11)

Hedbergella gorbachikae Longoria, 1974, p. 56, pl. 15, figs. 1-16.

Occurrence. A rare species in the upper Aptian to middle Albian (Globigerinelloides ferreolensis Zone to Ticinella praeticinensis Zone) of Site 545 .

\section{Hedbergella libyca Barr}

(Pl. 11, Figs. 5-9)

Hedbergella libyca Barr, 1972, p. 14, pl. 10, figs. 10a-c. Miles and Orr, 1980, pp. $798-799$, pl. 2, figs. 4-5.

Hedbergella costellata Saint-Marc. Caron, 1978, p. 658, pl. 4, figs. 1-3, 8-9.

Discussion. This species was widely distributed around the Atlantic and Tethys during the late Albian and earliest Cenomanian. It has significant biostratigraphic, and perhaps environmental, value. $\mathrm{H}$. costellata Saint-Marc (1973) was described from neritic deposits of Lebanon and determined to be of middle Cenomanian age. Further work may prove $H$. costellata to be synonymous with $H$. libyca. Based on the Atlantic and Libyan occurrences of $H$. libyca, its range is from the Planomalina praebuxtorfi-buxtorfi Zone (late Albian) to within the early part of the Rotalipora gandolfii Zone (earliest Cenomanian).

\section{Hedbergella paradubia (Sigal)}

(Pl. 11, Figs. 1-4)

Globigerina paradubia Sigal, 1952, p. 28, text-fig. 28.

Hedbergella brittonensis Loeblich and Tappan, 1961, pp. 274-275, pl. 4 , figs. 1-8.

Globigerina paradubia Sigal. Masters, 1977, p. 467, pl. 23, figs. 2-4; pl. 24 , fig. 1. 
Discussion. A somewhat variable species with 5 or 6 chambers in the final whorl and moderately low to high trochospire. Differs from $H$. planispira (Tappan) in being larger, having a higher trochospire, deeply depressed sutures, and deep umbilicus. Lower-spired forms with 5 chambers are distinguished from $\boldsymbol{H}$. delrioensis (Carsey) by their less-rapid increase in chamber size.

Occurrence. First appears in the upper part of the Biticinella breggiensis Zone and remains a persistent taxon throughout the upper Albian and Cenomanian of Sites 545 and 547.

\section{Hedbergella planispira (Tappan)}

(Pl. 9, Figs. 6-7)

Globigerina planispira Tappan, 1940, p. 122, pl. 19, fig. 12.

Hedbergella planispira (Tappan). Loeblich and Tappan, 1961, p. 276, pl. 5, figs. 4-11.

Discussion. This distinctive species is characterized by its small, flat test with 6-7-1/2 chambers in the last whorl. However, specimens from before the late Albian tend to be smaller than the late AlbianCenomanian forms.

Occurrence. A persistent and occasionally abundant species throughout the mid-Cretaceous of Sites 545 and 547.

\section{Hedbergella cf. rischi Moullade}

(Pl. 7, Figs. 11-12)

Hedbergella (Hedbergella) aff. infracretacea (Glaessner). Moullade, 1966 , pp. 89-90, pl. 8, figs. 6-9 (not figs. 10-16).

Hedbergella rischi Moullade, 1974, p. 1816.

Discussion. The middle Albian sediments of Site 545 contain a 6-chambered species which is similar to Hedbergella sp. 1 of the upper Aptian section; however, several million years probably separate their ranges. $H$. cf. rischi differs from $H$. delrioensis (Carsey) in possessing 6 rather than 5 chambers and lacks the small size and circular outline of $H$. planispira (Tappan).

Occurrence. Ranges from the Ticinella primula Subzone to the Ticinella praeticinensis Zone (middle Albian) of Site 545.

\section{Hedbergella aff. sigali Moullade}

(Pl. 1, Fig. 1)

Hedbergella (Hedbergella) sigali Moullade, 1966, p. 87, pl. 7, figs. 20-25.

Discussion. $H$. sigali has typically been reported from Barremian through early Aptian age strata $(H$. sigali to Globigerinelloides blowi zones). However, similar forms persistently range through the middle Albian of Site 545, and these may actually be recycled.

Occurrence. Persistent but rare through the upper Aptian to ?upper Albian of Site 545 (G. ferreolensis Subzone to the ?Biticinella breggiensis Zone).

\section{Hedbergella simplicissima (Magné and Sigal)}

$$
\text { (Pl. 8, Figs. 5-6) }
$$

Hastigerinella simplicissima Magné and Sigal, 1954, in Cheylan et al., pp. 487-488, pl. 14, figs. 11a-c.

Hedbergella amabilis Loeblich and Tappan, 1961, p. 274, pl. 3, figs. 1a-7b, 9. (not figs. 8, 10).

Hedbergella simplicissima (Magné and Sigal). Sliter, 1980, pl. 18, figs. $7-10$.

Occurrence. Rare to common throughout the upper Albian and Cenomanian.

\section{Hedbergella trocoidea (Gandolfi)}

(Pl. 3, Figs. 1-4)

Anomalina lorneiana (d'Orbigny) var. trocoidea Gandolfi, 1942, p. 99 , pl. 2 , figs. 1a-c; pl. 4 , figs. $2-3$; pl. 13, figs. $2 \mathrm{a}-\mathrm{b}, 5 \mathrm{a}-\mathrm{b}$. Hedbergella trocoidea (Gandolfi). Longoria, 1974, p. 69, pl. 17, figs. 1-16; pl. 18, figs. 3-5.

Discussion. $H$. trocoidea is distinguished from the early forms of Ticinella roberti s.1. (Gandolfi) by possessing embracing chambers, fewer chambers in the final whorl, and a closed umbilicus.

Occurrence. This distinctive species first appears in the late Aptian Globigerinelloides algerianus Zone and ranges through the middle Albian Ticinella primula Subzone (T. roberti s.1. Zone).

\section{Hedbergella aff. trocoidea (Gandolfi)}

$$
\text { (Pl. 3, Figs. 5-10) }
$$

Discussion. This group basically differs from true $H$. trocoidea (Gandolfi) in having fewer chambers; 5 to 6 rather than 7 to 8 . Earlier forms, particularly of the Globigerinelloides ferreolensis and $G$. algerianus zones, are also smaller than later forms and closely resemble early Aptian $H$. excelsa Longoria. $H$. aff. trocoidea essentially differs from $H$. excelsa in being larger; it is possible that $H$. excelsa represents an ancestor of the $H$. trocoidea stock. $H$. aff. trocoidea differs from $H$. hispaniae Longoria in having a moderate trochospire rather than flat dorsal side. Some specimens of $H$. aff. trocoidea appear gradational with Hedbergella sp. 1.

Occurrence. A fairly common and persistent species from the upper Aptian to the middle Albian of Site 545 (G. ferreolensis Zone to Ticinella praeticinensis Zone).

\section{Hedbergella sp. 1 \\ (Pl. 4, Figs. 5-8, 12)}

Description. Test medium-sized, chambers increase fairly rapidly in size as added with 6 chambers in the final whorl. Possesses a moderately wide and deep umbilicus. Aperture bordered by lip. Dorsally flat to slightly convex.

Discussion. This form is similar to $H$. planispira (Tappan) but lacks the characteristic circular outline and smaller size of that taxon. Differs from $H$. delrioensis (Carsey) in possessing 6 rather than 5 chambers in the final whorl and differs from $H$. occulta Longoria in lacking "deeply incised" sutures on the umbilical side. Hedbergella sp. 1 differs from $H$, aff. trocoidea in being flat dorsally, having an open umbilicus and chambers that increase more rapidly in size as added, although transitional specimens are common.

Occurrence. A persistent species in the upper Aptian of Site 545 (Globigerinelloides ferreolensis Zone through $H$. trocoidea Zone).

Hedbergella sp. 2

(Pl. 17, Figs. 8-11)

Hedbergella sp. Sliter, 1980, p. 369, pl. 18, figs. 11-14.

Description. Test medium sized with $4-1 / 2-5$ chambers in the final whorl. Inflated, globular chambers that increase in size very rapidly as added, causing an unusual, pseudo-enrolled coiling. On some specimens, aperture extends around to the spiral side of the test.

Occurrence. This unique taxon is restricted to a short stratigraphic interval in the lower upper Cenomanian (Rotalipora cushmani Zone) of Site 547.

Loeblichella spp.

(Pl. 3, Figs. 11-12)

Discussion. Rare specimens referrable to the genus Loeblicha occur sporadically through the upper Aptian-Albian successions of Sites 545 and 547.

\section{Clavihedbergella moremani (Cushman)}

(Pl. 8, Fig. 11-12)

Hastigerinella moremani Cushman, 1931, p. 86, pl. 11, figs. 1a-c (not $2,3)$

Clavihedbergella moremani (Cushman). Loeblich and Tappan, 1961, p. 279 , pl. 5, figs. 12-16.

Discussion. This distinctive taxon of the upper Albian (Biticinella breggiensis Zone) of Sites 545 and 547 is tentatively assigned to $C$. moremani. This species was originally described from the upper Cenomanian Eagle Ford Shale of Texas. A similar form, $C$. pentagonalis (Reichel), was described from the upper Albian of the Breggia Gorge section, Switzerland (level 26 of Gandolfi, 1942). This latter taxon is characterized by its bulbous chamber protuberances (see discussion by Luterbacher and Premoli Silva, 1962), a feature not noted in the original description of C. moremani. However, Loeblich and Tappan (1961) illustrate several specimens from the Eagle Ford Group (upper Cenomanian) with such bulbous chambers. Because of the limited stratigraphic occurrence of this taxon in the Leg 79 material, the possibility exists that $C$. moremani and $C$. pentagonalis are unrelated homeomorphs, but until more information is available regarding their ranges, synonomy is assumed and the senior $C$. moremani is utilized. 
Occurrence. A rare but persistent taxon through the upper Albian of Site 545 and 547.

\section{Clavihedbergella simplex (Morrow)}

(Pl. 8, Figs. 7-8)

Hastigerinella simplex Morrow, 1934, pp. 198-199, pl. 30, fig. 6 . Clavihedbergella simplex (Morrow). Masters, 1977, pp. 443-445, pl. 19, figs. 1-3.

Discussion. C. simplex has not previously been reported from early and middle Albian age strata. The older occurrences from Site 545 may actually be recycled homeomorphic clavihedbergellids from the Aptian, particularly the lower Aptian.

Occurrence. A persistent taxon throughout the upper Albian and Cenomanian of Sites 545 and 547.

\section{Clavihedbergella subcretacea (Tappan)}

(Pl. 8, Figs. 9-10)

Hastigerinella subcretacea Tappan, 1943, pp. 513-514, pl. 83, figs. 4a-c. Hedbergella amabilis Loeblich and Tappan, 1961, p. 274, pl. 3, figs. $8 \mathrm{a}-\mathrm{c}, 10 \mathrm{a}, \mathrm{b}$ (not 1a-7b, 9).

Clavihedbergella subcretacea (Tappan). Masters, 1977, pp. 445-446, pl. 19, figs. 4-6.

Discussion. C. subcretacea is distinguished from C. simplex (Morrow) by possessing 6-6 $1 / 2$ chambers in the final whorl rather than 4-5.

Occurrence. A characteristic species of the lower Biticinella breggiensis Zone (upper Albian) of Sites 545 and 547.

\section{Praeglobotruncana delrioensis (Plummer)}

(Pl. 12, Figs. 1-8)

Globorotalia delrioensis Plummer, 1931, pp. 199-200, pl. 13, figs. 2a-c. Praeglobotruncana delrioensis (Plummer). Loeblich and Tappan, 1961, p. 280 , pl. 6, figs. 9-12.

Occurrence. A characteristic species of the upper Albian (Planomalina praebuxtorfi-buxtorfi Zone) through Cenomanian of Sites 545 and 547.

\section{Praeglobotruncana stephani (Gandolfi)}

(Pl. 12, Figs. 9-12)

Globotruncana stephani Gandolfi, 1942, pp. 130-133, pl. 3, figs. 4, 5; pl. 4 , figs. 36, 37, 41-44; pl. 6, fig. 4 (part); pl. 9, figs. 5, 8, pl. 14, fig. 2.

Praeglobotruncana stephani (Gandolfi). Loeblich and Tappan, 1961, p. 284 , pl. 6 , figs. $1-8$.

Occurrence. Persistent throughout the upper Albian (Planomalina praebuxtorfi-buxtorfi Zone) and Cenomanian of Sites 545 and 547.

\section{Biticinella breggiensis (Gandolfi)}

(PI. 8, Figs. 1-2)

Anomalina breggiensis Gandolfi, 1942, pp. 102-103, pl. 3, figs. 6a-c; pl. 5, fig. 3; pl. 9, fig. 1; pl. 13, figs. 7a-8b; text-figs. 34 (1-4).

Biticinella breggiensis (Gandolfi). Caron and Luterbacher, 1969, p. 25 , pl. 7, figs. 4a-c.

Occurrence. Primarily restricted to the upper Albian B. breggiensis Zone although questionable specimens of $B$. breggiensis occur in the upper middle Albian Ticinella praeticinensis Zone of Site 545.

\section{Ticinella madecassiana Sigal}

(Pl. 6, Figs. 7-12)

Ticinella madecassiana Sigal, 1966, pp. 197-198, pl. 3, figs. 7a-10b. Discussion. T. madecassiana is distinguished from T. primula Luterbacher by possessing fewer chambers (5-6) and a narrower umbilicus. Ventrally, many specimens superficially resemble Globigerinelloides bentonensis (Morrow) in chamber shape and arrangement. T. madecassiana has a tendency toward pseudoplanispiral coiling that adds to its possible confusion with $G$. bentonensis. $T$. caronae Longoria and Gamper (1977; p. 212, pl. 1, figs. 1-3 and 13-15) may be synonymous with $T$. madecassiana. The specimens tentatively identified as Hedbergella sp. aff. infracretacea by Moullade (1966, pl. 8, figs. 10-12, 14-16; not figs. 6-9) also resemble $T$. madecassiana.

Occurrence. A characteristic species throughout the Biticinella breggiensis and lower Planomalina praebuxtorfi-buxtorfi zones (upper Albian) of Sites 545 and 547.
Ticinella primula Luterbacher

$$
\text { (Pl. 6, Figs. 1-6) }
$$

Ticinella primula Luterbacher, in Renz et al., 1963, pp. 1083-1086, text-fig. 4. Sigal, 1966 , pp. $198-199$, pl. 3 , figs. $11-14 ;$ pl. 4 , figs. $1-9$.

Discussion. T. primula is a variable species with $6-1 / 2-8$ chambers in the final whorl. The size of the accessory apertures varies considerably. As observed by other workers, there is a tendency towards pseudoplanispiral coiling in larger specimens (Pl. 6, Figs. 5). It is distinguished from $T$. roberti s.l. (Gandolfi) by its less embracing chambers, a peripheral outline that is elliptical rather than circular, and flatter dorsoconvexity. $T$. primula differs from $T$. raynaudi s.l. Sigal by its less elongate chambers, and is distinguished from T. madecassiana Sigal by its more numerous chambers, looser coiling, and wider umbilicus.

Occurrence. A characteristic taxon from the middle Albian T. primula Subzone through the upper Albian Biticinella breggiensis Zone.

\section{Ticinella praeticinensis Sigal}

(Pl. 13, Figs. 9-10)

Ticinella praeticinensis Sigal, 1966, pp. 195-196, pl. 2, figs. 3-8; pl. 3, figs. 1-6.

Discussion. Specimens transitional with T. roberti s.l. (Gandolfi) are present in the lower part of the T. praeticinensis Zone at Site 545. However, both species "disappear" in the upper part of that zone because of environmental exclusion/dissolution. T. praeticinensis is similar to Rotalipora praebalernaensis Sigal and maybe its direct ancestor; however, the development of a true keel in the latter species distinguishes the two forms.

Occurrence. Rare specimens present in the Ticinella praeticinensis Zone (upper middle Albian) with additional occurrences into the upper Albian of Sites 545 and 547.

Ticinella raynaudi s.I. Sigal

(Pl. 7, Figs. 1-4; Pl. 8, Figs. 3-4)

Ticinella raynaudi var. raynaudi Sigal, 1966, pp. 201-202, pl. 5, fig. 10; pl. 6, figs. 1-5; var. digitalis Sigal, 1966, p. 202, pl. 6, figs. 6-8; var. aperta Sigal, 1966, pp. 202-203, pl. 6, figs. 11-13.

Discussion. The $T$. raynaudi group is differentiated from other species of Ticinella in possessing more elongate chambers. Although recognizing a true distinction between $T$. raynaudi s.l. and other ticinellids, the author finds it difficult to recognize all three varieties of $T$. raynaudi. The one most easily recognized is $T$. raynaudi digitalis. The varieties raynaudi and, particularly, aperta appear to be transitional with $T$. primula Luterbacher. $T$. raynaudi s.l. is, however, a biostratigraphically useful species group.

Occurrence. A characteristic species of the upper Albian Biticinella breggiensis Zone of Sites 545 and 547.

\section{Ticinella roberti s.l. (Gandolfi)}

(Pl. 5, Figs. 1-12)

Anomalina roberti Gandolfi, 1942, pp. 100-101, fig. 22; pl. 2, fig. 2; pl. 4, figs. 5-7; pl. 13, figs. 3, 6 .

Ticinella roberti (Gandolfi) var. bejaouaensis Sigal, 1966, p. 207, pl. 5, figs. 5-9.

Ticinella roberti (Gandolfi). Hermes, 1969, pp. 35-40, 42-43, pl. 1, figs. $1-3$; pl. 2, figs. $28-47$; pl. 3 , figs. 56-60.

Discussion. Sigal (1966) differentiated the variety $T$. roberti bejaouaensis from $T$. roberti s.s. based on more chambers in the last whorl (averaging 9) and a more open umbilicus. To the contrary, Longoria (1974) notes that $T$. bejaouaensis differs from $T$. roberti in having a smaller umbilicus. Based on the material from this study it is difficult to recognize any distinct differences between $T$. roberti and $T$. bejaouaensis. In trying to assess the true biostratigraphic significance of the $T$. roberti group, it becomes evident from the literature that discrepancies exist between various workers concerning the ranges of " $T$. rober$t i$ " and "T. bejaouaensis" (see discussion by Hermes, 1969). For example, Sigal (1966) reports a range for $T$. roberti of latest Aptian (Clansayesian) to within the Vraconian (latest Albian) and a concurrent range for $T$. bejaouaensis to within the middle Albian. Other workers (Risch, 1971; Longoria, 1974; Moullade, 1974) report two distinct, nonoverlapping ranges; $T$. bejaouaensis representing a late Aptian-early Albian form and $T$. roberti present only in the late Albi- 
an. These latter observations imply that the two forms are homeomorphic and unrelated species. This possibility cannot be confirmed nor denied in the present study because of the environmental exclusions/ dissolution observed in the middle Albian of Site 545. However, at Site $545 T$. roberti s.l. has an overlapping range with $T$. praeticinensis $\mathrm{Si}-$ gal, a species long thought to represent the transition from $T$. roberti to the Rotalipora subticinensis (Gandolfi)- $R$. ticinensis (Gandolfi) lineage (Gandolfi, 1942; Hermes, 1969).

Occurrence. A persistent taxon from the latest Aptian (T. roberti s.l. Zone) through late Albian (Biticinella breggiensis Zone). A stratigraphic gap occurs in the middle Albian ( $T$. praeticinensis and ?lower Biticinella breggiensis zones) of Site 545 .

\section{Rotalipora appenninica (Renz)}

(Pl. 14, Figs. 1-12)

Globotruncana appenninica Renz, 1936, p. 14, fig. 2; var. alpha Gandolfi, 1942, p. 117, text-figs. 40a-c.

Rotalipora appenninica appenninica (Renz). Luterbacher and Premoli Silva, 1962, pp. 266-268, pl. 19, figs. 1, 2; pl. 20, figs. 1-4; pl. 21, figs. 1-4.

Rotalipora appenninica (Renz). Caron and Luterbacher, 1969, p. 26, pl. 8, fig. 8. Robaszynski and Caron, 1979, p. 59, 64; pl. 4, figs. $1 \mathrm{a}-3 \mathrm{c} ;$ pl. 5 , figs. $1 \mathrm{a}-3 \mathrm{c}$.

Discussion. Early specimens tend to have a less strongly developed peripheral keel. $R$. appenninica is generally flatter than $R$. gandolfii Luterbacher and Premoli Silva and lacks the periumbilical flanges of the latter species. $R$. appenninica differs from $R$. aff. cushmani in lacking elongate sutural supplementary apertures and having a narrower umbilicus. A transitional specimen between $R$. appenninica and $R$. aff. cushmani is illustrated on Plate 14, Figures 1-3.

Occurrence. A characteristic and persistent species from the Planomalina praebuxtorfi-buxtorfi Zone through the Rotalipora gandolfii Zone (upper Albian to middle Cenomanian) of Sites 545 and 547.

\section{Rotalipora cushmani (Morrow)}

Globorotalia cushmani Morrow, 1934, p. 199, pl. 31, figs. 2, 4. Rotalipora cushmani (Morrow). Loeblich and Tappan, 1961, pp. 297298, pl. 8, figs. 1-10.

Rotalipora cushmani (Morrow). Robaszynski and Caron, 1979, p. 69, 74; pl. 7, figs. 1a-c; pl. 8, figs. 1a-2c.

Discussion. $R$. cushmani is characterized by its triangular-shaped chambers on the umbilical side, wide umbilicus, sutural secondary apertures, and inflated chambers on both the ventral and dorsal sides. The lack of inflation, particularly on the dorsal side, serves to distinguish $R$. aff. cushmani from $R$. cushmani.

Occurrence. Characteristic of the upper Cenomanian (Rotalipora cushmani Zone) of Site 547.

\section{Rotalipora aff. cushmani}

(Pl. 16, Figs. 1-6)

Discussion. Rotalipora aff. cushmani is more compressed and lacks the inflation of true R. cushmani (Morrow). The chambers on the spiral side are not inflated and dorsal convexity is low. Inflation of the umbilical side is variable. The Let 79 specimens of $R$. aff. cushmani are not equivalent to $R$. montsalvensis (Mornad) because they are less inflated and possess beaded intercameral dorsal sutures. Interestingly, $R$. aff. cushmani appears to have a stratigraphic range consistent with that of $R$. montsalvensis as proposed by Robaszynski and Caron (1979).

Occurrence. Ranges from the mid $R$. gandolfii Zone through the $R$. reicheli Zone (late early Cenomanian to middle Cenomanian).

\section{Rotalipora gandolfii Luterbacher and Premoli Silva}

(Pl. 15, Figs. 5-12)

Globotruncana appenninica var. typica Gandolfi, 1942, pp. 116-123, text-fig. 43 (2, 3); pl. 2, fig. 6; pl. 4, figs. 13, 14; pl. 9, fig. 6; pl. 12, figs. 4-6; pl. 14, figs. 3, 4.

Rotalipora appenninica gandolfii Luterbacher and Premoli Silva, 1962, pp. $267-268$, pl. 19, fig. 3 .

Rotalipora gandolfii Luterbacher and Premoli Silva. Caron and Luterbacher, 1969, pp. 26-27, pl. 9, fig. 9. Robaszynski and Caron, 1979 , p. 81,84 ; pl. 11 , figs. 1a-2c.

Discussion. $R$. gandolfii tends to be higher ventrally than $R$. appenninica (Renz) and also differs from the latter species in having periumbilical flanges (umbilical shoulders) on all chambers. $R$. gandolfii lacks the strongly oblique spiral sutures of $R$. greenhornensis (Morrow) and development of raised umbilical sutures (horseshoes).

Occurrence. A characteristic species from the uppermost Albian (Planomalina praebuxtorfi-buxtorfi Zone) through the lower upper Cenomanian of Sites 545 and 547.

\section{Rotalipora greenhornensis (Morrow) \\ (Pl. 15, Figs. 1-4; Pl. 16, Figs. 7-12)}

Globorotalia greenhornensis Morrow, 1934, p. 199, pl. 31, fig. 1. Rotalipora greenhornensis (Morrow). Loeblich and Tappan, 1961, pp. 299-301, pl. 7, figs. 5-10. Robaszynski and Caron, 1979, p. 85, 90 ; pl. 12 , figs. $1 \mathrm{a}-2 \mathrm{c} ;$ pl. 13 , figs. $1 \mathrm{a}-2 \mathrm{c}$.

Discussion. The author agrees with Loeblich and Tappan (1961) that $R$. globotruncanoides Sigal and Thalmanninella brotzeni Sigal are both synonymous with $R$. greenhornensis. As noted by Eicher and Worstell (1970), this species varies considerably in dorsal convexity. The specimens of this study typically have $6-7-1 / 2$ chambers in the final whorl. $R$. greenhornensis is distinguished from $R$. gandolfii Luterbacher and Premoli Silva by having strongly oblique sutures on the spiral side, a tendency toward a more pronounced asymmetrical test, raised umbilical sutures (horseshoes), and welldeveloped umbilical supplementary apertures.

Occurrence. First appears in the $R$. gandolfii Zone (lower Cenomanian) and ranges into the upper Cenomanian of Sites 545 and 547.

\section{Rotalipora micheli (Sacal and Debourle)}

$$
\text { (Pl. 17, Figs. 3-7) }
$$

Globotruncana (Rotalipora) micheli Sacal and Debourle, 1957, p. 58, pl. 25 , figs. $4,5,12$.

Rotalipora micheli (Sacal and Debourle). Robaszynski and Caron, 1979, p. 91,$94 ;$ pl. 14, figs. 1a-3c.

Discussion. Rotalipora marchigiana (Borsetti), originally described from thin section, may be synonymous with $R$. micheli. $R$. micheli is distinguished from $R$. appenninica (Renz) by its greater inflation on the umbilical side and the presence of adumbilical thickenings which gives the test its distinctive asymmetrical axial profile. $R$. micheli is more inflated ventrally than $R$. gandolfii Luterbacher and Premoli Silva and also lacks the development of true periumbilical flanges as observed in the latter species.

Occurrence. Rare from the lower $R$. gandolfii Zone through the $R$. reicheli Zone (lower to middle Cenomanian).

\section{Rotalipora praebalernaensis Sigal}

(Pl. 13, Figs. 4, 8, 11-12)

Rotalipora praebalernaensis Sigal, 1969, pp. 635-637, pl. 1, figs. 1-8. Discussion. $R$. praebalernaensis differs from $R$. subticinensis (Gandolfi) in possessing fewer chambers (6-7), in being flatter dorsally, and having a more lobate periphery. $R$. praebalernaensis is distinguished from $R$. appenninica (Renz) by a less well developed peripheral keel and more circular outline.

Occurrence. A rare species in the Biticinella breggiensis Zone (late Albian).

\section{Rotalipora reicheli (Mornod)}

$$
\text { (PI. 17, Figs. 1-2) }
$$

Globotruncana appenninica var. gamma Gandolfi, 1942, p. 116. Globotruncana (Rotalipora) reicheli Mornod, 1950, p. 583, fig. 5(4); fig. 6 (1-6); pl. 25, figs. 3-4.

Rotalipora reicheli (Mornod). Caron and Luterbacher, 1969, p. 27, pl. 9, fig. 10. Robaszynski and Caron, 1979, p. 99, 106; pl. 16, figs. 1a-c; pl. 17, figs. 1a-c; pl. 18, figs. 1a-2c.

Rotalipora deeckei (Franke). Masters, 1977, pp. 506-508, pl. 32, figs. 1-3.

Occurrence. This distinctive taxon is very rare at Sites 545 and 547, apparently restricted to the $R$. reicheli Zone.

\section{Rotalipora subticinensis (Gandolfi)}

$$
\text { (Pl. 13, Figs. 5-7) }
$$

Globotruncana ticinensis var. alpha Gandolfi, 1942, p. 114, pl. 2, figs. $4 a-c ;$ pl. 8 , fig. 3 .

Globotruncana (Thalmanninella) ticinensis subticinensis Gandolfi, 1957 , p. 59 , pl. 8 , figs. 1 a-c. 
Rotalipora subticinensis (Gandolfi). Robaszynski and Caron, 1979, p. 107, 110; pl. 19, figs. 1a-2d.

Occurrence. Restricted to the lower part of the Biticinella breggiensis Zone (upper Albian) of Sites 45 and 547.

\section{Rotalipora ticinensis (Gandolfi)}

(Pl. 13, Figs. 1-3)

Globotruncana ticinensis typica Gandolfi, 1942, pp. 113-115, text-fig. 39 , pl. 2, figs. 3a-c; pl. 5, fig. 2; pl. 8, figs. 4-6.

Rotalipora ticinensis (Gandolfi). Robaszynski and Caron, 1979, p. 111, 114; pl. 20, figs. 1a-2b.

Occurrence. A characteristic species throughout the Biticinella breggiensis and lower Planomalina praebuxtorfi-buxtorfi Zones.

Gen. indet., sp. indet.

(PI. 7, Figs. 5-6, 9-10)

Description. Test small, stout. Chambers increase fairly rapidly in size as added, inflated, strongly embracing; 5 chambers in the final whorl. Umbilicus closed. Aperture low, slitlike with thin lip. Low trochospire. Generic assignment uncertain.

Occurrence. This distinctive taxon has a short stratigraphic range in late middle or early late Albian age strata of Site 545. It is associated with the interval of lowest planktonic diversity and a presumed harsh ?preservational environment.

\section{ACKNOWLEDGMENTS}

The author gratefully acknowledges the critical and thorough reviews by D. L. Eicher and R. Diner (University of Colorado), W. Sliter (USGS, Menlo Park), and P. N. Webb (Ohio State University). Acknowledgment is made to the donors of The Petroleum Research Fund, administered by the American Chemical Society for research support. A very special thanks is extended to Amoco Production in Denver and particularly to Mike Mellor for use and operation of the scanning electron microscope. Enthusiastic support and typing by P. Leckie are greatly appreciated.

\section{REFERENCES}

Arthur, M. A., and Schlanger, S. O., 1979. Cretaceous "Oceanic Anoxic Events" as causal factors in development of reef-reservoired giant oil fields. Am. Assoc. Pet. Geol. Bull., 63(6):870-885.

Barr, F. T., 1972. Cretaceous biostratigraphy and planktonic foraminifera of Libya. Micropaleontology, 18(1):1-46.

Berger, W. H., 1970. Biogenous deep-sea sediments: fractionation by deep-sea circulation. Geol. Soc. Am. Bull., 81(6):1385-1402.

Bolli, H., 1959. Planktonic foraminifera from the Cretaceous of Trinidad, B.W.I. Bull. Am. Paleontol., 39(179):258-277.

Bolli, H., Loeblich, A. R., Jr., and Tappan, H., 1957. Planktonic foraminiferal families Hantkeninidae, Orbulinidae, Globorotaliidae and Globotruncanidae. In Loeblich, A. R., Jr., Tappan, H., Beckmann, J. P., et al. (Ed.), Studies in Foraminifera. Bull. U.S. Nat. Museum, 215:3-50.

Butt, A., 1982. Micropaleontological bathymetry of the Cretaceous of western Morocco. Palaeogeogr., Palaeoclimatol., Palaeoecol., 37: 235-275.

Caron, M., 1978. Cretaceous planktonic foraminifers from DSDP Leg 40, southeastern Atlantic Ocean. In Bolli, H. M., Ryan, W. B. F., et al., Init. Repts. DSDP, 40: Washington (U.S. Govt. Printing Office), 651-678.

Caron, M., and Luterbacher, H. P., 1969. On some type specimens of Cretaceous planktonic foraminifera. Contrib. Cushman Fdn. Foramin. Res., 20(1):23-29.

Carsey, D. O., 1926. Foraminifera of the Cretaceous of central Texas. Bull. Univ. Tex. Bur. Econ. Geol. Technol., 2612:1-56.

Chevalier, J., 1961. Quelques nouvelles espèces de Foraminifères dans le Crétacé inférieur Méditerranéen. Rev. Micropaleontol., 4(1): 30-36.

Cheylan, G., Magné, J., Sigal, J., and Grekoff, N., 1954. Résultats géologiques et micropaléontologiques du sondage d'El Krachem (Hauts plateaux Algérois). Description de quelques espèces nouvelles. Bull. Soc. Geol. Fr., Ser. 6, 3(1953), fasc. 4-6:471-492.

Cushman, J. A., 1931. Hastigerinella and other interesting foraminifera from the Upper Cretaceous of Texas. Contrib. Cushman Lab. Foramin. Res., 7(4):83-90.
1938. Cretaceous species of Guembelina and related genera. Contrib. Cushman Lab. Foramin. Res., 14(1):2-28.

Cushman, J. A., and ten Dam, A., 1948. Globigerinelloides, a new genus of the Globigerinidae. Contrib. Cushman Lab. Foramin. Res., 24(2):42-43.

Cushman, J. A., and Wickenden, R. T. D., 1930. The development of Hantkenina in the Cretaceous with a description of a new species. Contrib. Cushman Lab. Foramin. Res., 6(2):39-43.

Diester-Haass, L., 1978. Sediments as indicators of upwelling. In Boje, R., and Tomczak, M. (Eds.), Upwelling Ecosystems: New York (Springer-Verlag), pp. 261-281.

Dupeuble, P. A., 1979. Mesozoic foraminifers and microfacies from Holes 400A, 401, and 402A of DSDP Leg 48. In Montadert, L., Roberts, D. G., et la., Init. Repts. DSDP, 48: Washington (U.S. Govt. Printing Office), 451-473.

Eicher, D. L., and Worstell, P., 1970. Cenomanian and Turonian foraminifera from the Great Plains, United States. Micropaleontology, 16(3):269-324.

Einsele, G., and Wiedmann, J., 1982. Turonian black shales in the Moroccan coastal basins: first upwelling in the Atlantic Ocean? In von Rad, U., Hinz, K., Sarnthein, M., and Seibold, E. (Eds.), Geology of the Northwest African Continental Margin: New York (Springer-Verlag), pp. 396-414.

1983. Cretaceous upwelling off northwest Africa: a summary. In Thiede, J., and Suess, E. (Eds.), Coastal Upwelling, Its Sediment Record-Part B: Sedimentary Records of Ancient Coastal Upwelling: New York (Plenum Press), pp. 485-499.

Gandolfi, R., 1942. Ricerche micropaleontologiche e stratigrafiche sulla Scaglia e sul flysch Cretacici dei dintorni di Balerna (Canton Ticino). Mem. Riv. Ital. Paleont., 48(4):1-160.

1957. Notes on some species of Globotruncana. Contrib. Cushman Fdn. Foramin. Res., 8(2):59-65.

Glaessner, M., 1937. Planktonforaminiferen aus der Kreide und dem Eozän und ihre stratigraphische Bedeutung. Etyudy Mikropaleont., $1(1): 27-52$.

Hermes, J. J., 1969. Late Albian foraminifera from the Subbetic of southern Spain. Geol. Mijnbouw, 48(1):35-65.

Keller, B. M., 1935. Microfauna of the upper Cretaceous of the Dnieper-Donets Valley and some other adjoining regions. Byull. Mosk. Obshch. Ispyt. Prir., n.s., 43, Sect. Geol., 13(4):522-558.

Lancelot, Y., and Winterer, E. L. 1980. Evolution of the Moroccan oceanic basin and adjacent continental margin-a synthesis. In Lancelot, Y., Winterer, E. L., et al., Init. Repts. DSDP, 50: Washington (U.S. Govt. Printing Office), 801-821.

Loeblich, A. R., Jr., and Tappan, H., 1961. Cretaceous planktonic foraminifera: Part I-Cenomanian. Micropaleontology, 7(3): 257-304.

Longoria, J. F., 1974. Stratigraphic, Morphologic and Taxonomic studies of Aptian Planktonic Foraminifera. Rev. Espan. Micropaleontol., Spec. Issue.

Longoria, J. F., and Gamper, M. A., 1977. Albian planktonic foraminifera from the Sabinas Basin of northern Mexico. J. Foram. Res., 7(3):196-215.

Luterbacher, H., and Premoli Silva, I., 1962. Note préliminaire sur une révision du profil de Gubbio, Italie. Riv. Ital. Paleont. Stratigr., 68(2):253-288.

Masters, B. A., 1977. Mesozoic planktonic foraminifera, a worldwide review and analysis. In Ramsay, A. T. S. (Ed.), Oceanic Micropaleontology (Vol. 1): New York (Academic Press), 301-731.

Miles, G. A., and Orr, W. N., 1980. Planktonic foraminifers from the Bermuda Rise, DSDP Legs 51, 52 and 53. In Donnelly, T., Francheteau, J., Bryan, W., Robinson, P., Flower, M., Salisbury, M., et al., Init. Repts. DSDP, 51, 52, 53, Pt. 2: Washington (U.S. Govt. Printing Office), 791-813.

Mornod, L., 1950. Les Globorotalides du Crétacé supérieur du Montsalvens (Préalpes fribourgeoises). Eclogae Geol. Helv., 42(2): 573-596.

Morrow, A. L., 1934. Foraminifera and ostracoda from the Upper Cretaceous of Kansas. J. Paleontol., 8(2):186-205.

Moullade, M., 1961. Quelques foraminifères et ostracodes nouveaux du Crétacé inférieur Vocontien. Rev. Micropaleontol., 3(4):213-216. , 1966. Etude stratigraphique et micropaleontoloque du Crétacé inférieur de la "Fosse Vocontienne." Doc. Lab. Geol. Fac. Sci. Lyon, 15:1-369. 
1974. Zones de Foraminifères du Crétacé inférieur mésogéen. C. R. Acad. Sci., Série D, 278:1813-1816.

Pessagno, E. A., Jr., 1967. Upper Cretaceous planktonic foraminifera from the western Gulf Coastal Plain. Palaeontogr. Am., 5(37): 245-445.

Pflaumann, U., and Čepek, P. 1982. Cretaceous foraminiferal and nannoplankton biostratigraphy and paleoecology along the West African continental margin. In von Rad, U., Hinz, K., Sarnthein, M., Seibold, E. (Eds.), Geology of the Northwest African Continental Margin: New York (Springer-Verlag), pp. 309-353.

Plummer, H. J., 1931. Some Cretaceous foraminifera in Texas. Bull. Univ. Tex. Bur. Econ. Geol. Technol., 3101:109-203.

Premoli Silva, I., and Boersma, A., 1977. Cretaceous planktonic foraminifers-DSDP Leg 39 (South Atlantic). In Supko, P. R., PerchNielsen, K., et al., Init. Repts. DSDP, 39: Washington (U.S. Govt. Printing Office), 615-641.

Reichel, M., 1948. Les Hantkéninidés de la Scaglia et des Couches rouges (Crétacé supérieur). Eclogae Geol. Helv., 40(2) (1947): 391-409.

Renz, O., 1936. Stratigraphische und mikropaläontologische Untersuchung der Scaglia (Obere Kreide-Tertiär) in zentralen Apennin. Eclogae Geol. Helv., 29(1):1-149.

Renz, O., Luterbacher, H., and Schneider, A., 1963. Stratigraphischepaläontologische untersuchungen im Albien und Cenomanien des Neuenburger Jura. Eclogae Geol. Helv., 56(2):1076-1116.

Risch, H., 1971. Stratigraphie der höheren Unterkreide der Bayerischen Kalkalpen mit Hilfe von Mikrofossilien. Palaeontographica A, 138(1-4):1-80.

Robaszynski, F., and Caron, M. (Eds.), 1979. Cahiers de Micropaleontologie, Atlas de Foraminiféres Planctoniques de Crétacé Moyen (Mer Boréale et Tethys). Ed. CNRS. Pts. 1 and 2.

Sacal, V, and Debourle, A., 1957. Foraminifères d'Aquitaine. II. Peneroplidae a Victoriellidae. Mem. Soc. Geol. Fr., N.S., 36(78):1-81.

Saint-Marc, P., 1973. Presence de Hedbergella à "costellae" dans le Cénomanien moyen du Liban. J. Foram. Res., 3(1):7-12.
Schacko, G., 1897. Beitrag über Foraminiferen aus der Cenoman-Kreide von Moltzow in Mecklenburg. Arch. Ver. Freunde Naturg. Mecklenb., 50(1896):161-168.

Sigal, J., 1952. Aperçu stratigraphique sur la micropaléontologie du Crétacé. Alger. 19th Int. Geol. Congr., Monogr. Reg., 1st Ser., No. 26:1-45.

1966. Contribution à une monographie des Rosalines. 1. Le genre Ticinella Reichel, souche des Rotalipores. Eclogae Geol. Helv., 59(1):185-217.

1969. Contribution à une monographie des Rosalines. 2. L'espèce Rotalipora appenninica (O. Renz, 1936), origine phyletique et taxinomie. In Brönnimann, P., and Renz, H. H. (Eds.), Proc. I Planktonic Conf., 2: Leiden (E. J. Brill), 622-639.

Sliter, W. V., 1980. Mesozoic foraminifers and deep-sea benthic environments from DSDP Sites 415 and 416, eastern North Atlantic. In Lancelot, Y., Winterer, E. L., et al., Init. Repts. DSDP, 50: Washington (U.S. Govt. Printing Office), 353-427.

Subbotina, N. N., 1949. Microfauna of the U.S.S.R. Trudy, vses. nauchno-issled. geol.-razv. Inst. n.s., 34:33-35. (in Russian)

Tappan, H., 1940. Foraminifera from the Grayson Formation of northern Texas. J. Paleontol., 14(2):93-126.

1943. Foraminifera from the Duck Creek Formation of Oklahoma and Texas. J. Paleontol., 17(5):476-517.

van Hinte, J. E., 1976. A Cretaceous time scale. Am. Assoc. Pet. Geol. Bull., 60(4):489-516.

Wonders, A. A. H., 1975. Cretaceous planktonic foraminifera of the Planomalina buxtorfi group from El Burrueco, southern Spain. Proc. K. Nederl. Akad. Wetensch., Series B, 78(2):83-93. 1980. Middle and Late Cretaceous Planktonic Foraminifera of the Western Mediterranean Area. Utrecht Micropaleontol. Bull., 24.

Date of Initial Receipt: February 15, 1984 Date of Acceptance: March 28, 1984 


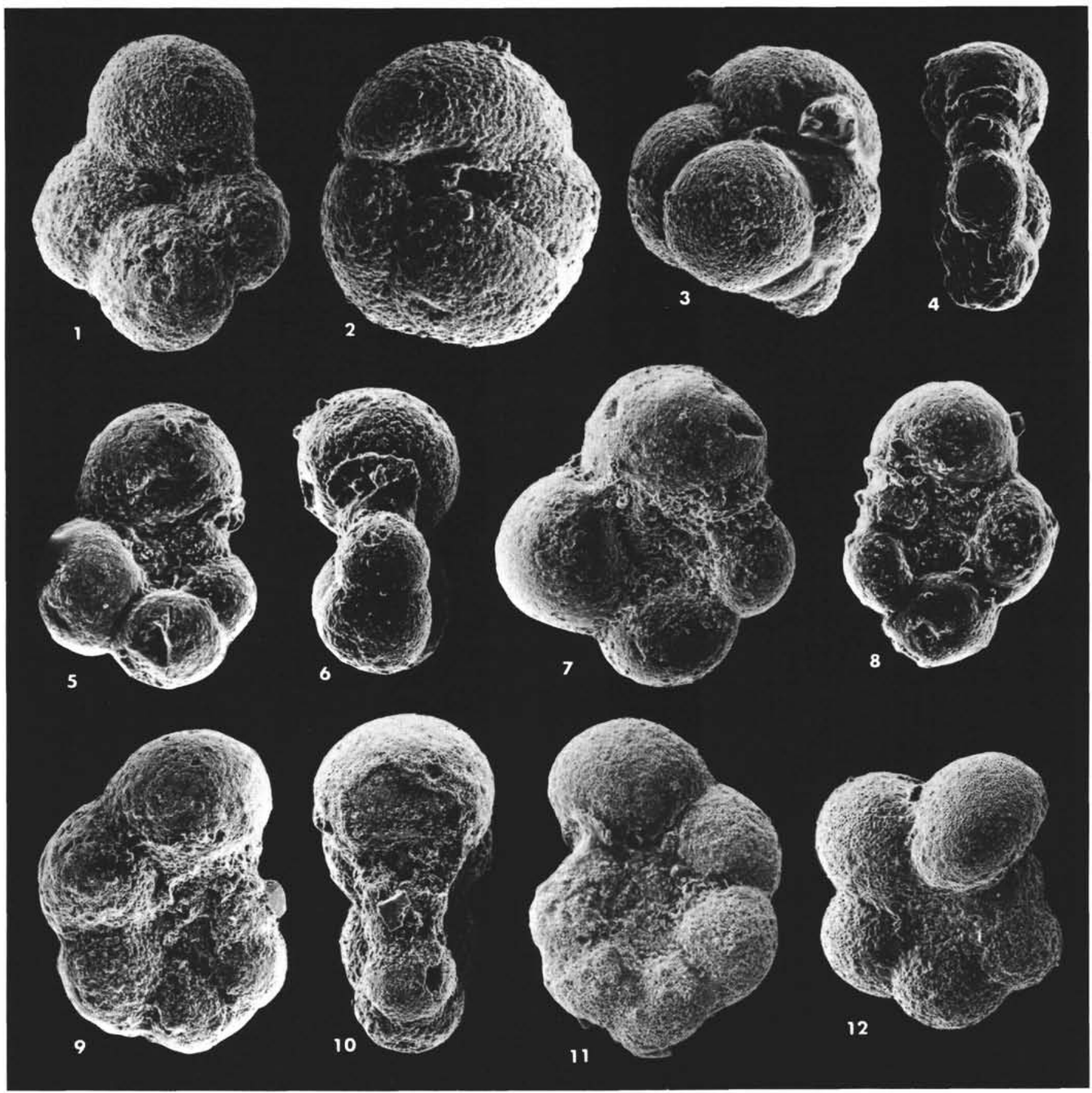

Plate 1. Late Aptian. 1. Hedbergella aff. sigali, 545-56-5, 62-64 cm (max. diam. 0.14 mm). 2-3. Gubkinella graysonensis, (2) 545-44,CC (max. diam. $0.10 \mathrm{~mm})$, (3) 545-54,CC (max. diam. 0.16 mm). 4-8. Globigerinelloides blowi s.1., (4-6, 8) 545-54,CC (4, 8, max. diam. 0.15 mm; 5-6, max. diam. $0.12 \mathrm{~mm}$; (7) 545-55-4, 87-89 cm (max. diam. 0.16 mm). 9-11. Globigerinelloides aptiense, (9-10) 545-52-1, 81-86 cm (max. diam. $0.21 \mathrm{~mm}$ ); (11) 545-55-5, 4-6 cm (max. diam. $0.14 \mathrm{~mm}$ ). 12. Hedbergella delrioensis, early form, 545-56-3, 54-56 cm (max. diam. 0.23 mm). 


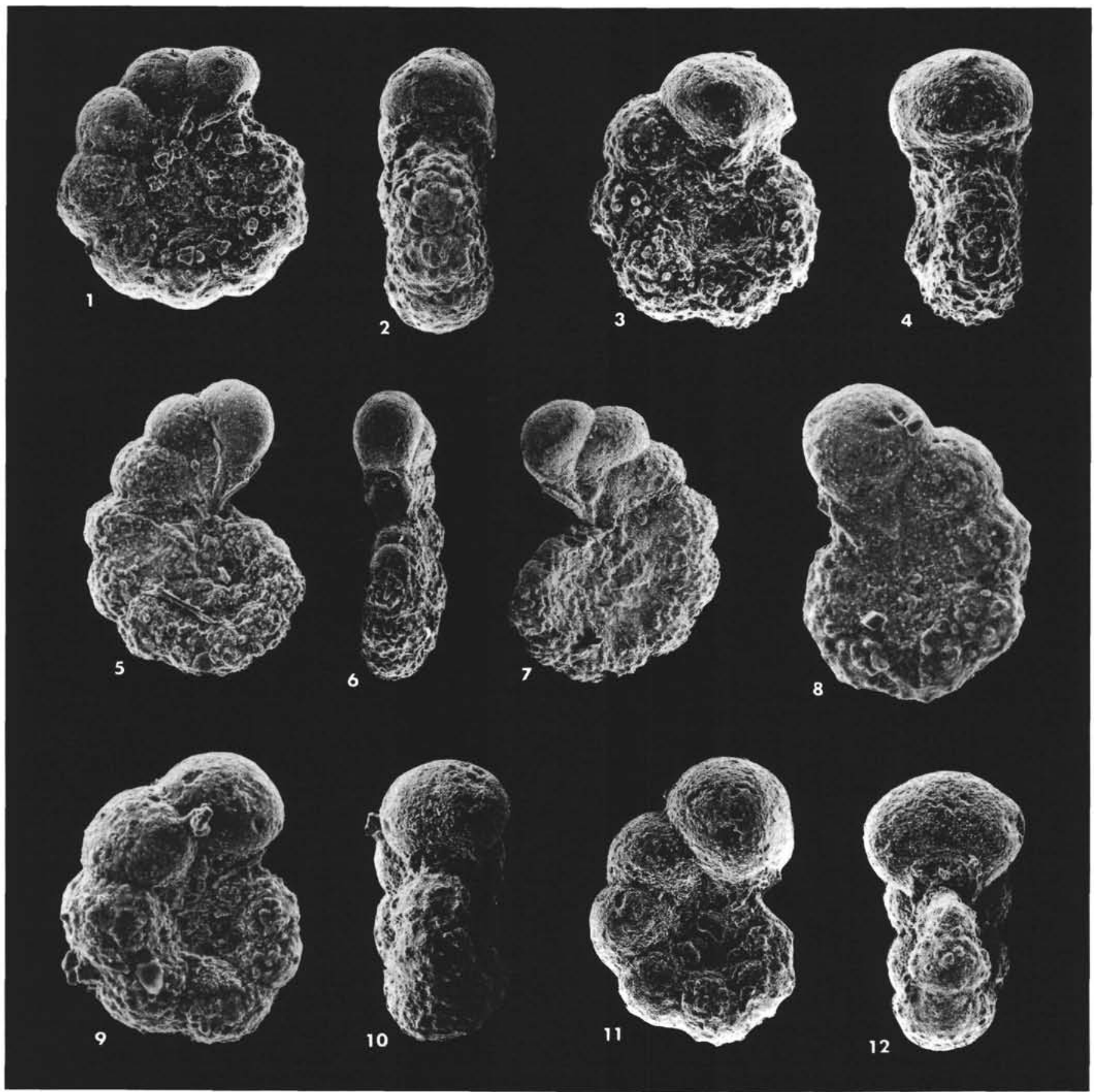

Plate 2. Late Aptian. 1-4. Globigerinelloides barri, (1-2) 545-54,CC (max. diam. $0.40 \mathrm{~mm}$ ), (3-4) 545-52,CC (max. diam. 0.38 mm). 5-8. Globigerinelloides algerianus, 545-54,CC, (5-7) max. diam. $0.70 \mathrm{~mm},(8) \max$. diam. $0.30 \mathrm{~mm}$. 9-12. Globigerinelloides ferreolensis, 545-54,CC, (9-10) max. diam. $0.30 \mathrm{~mm}$, (11-12) max. diam. $0.30 \mathrm{~mm}$. 


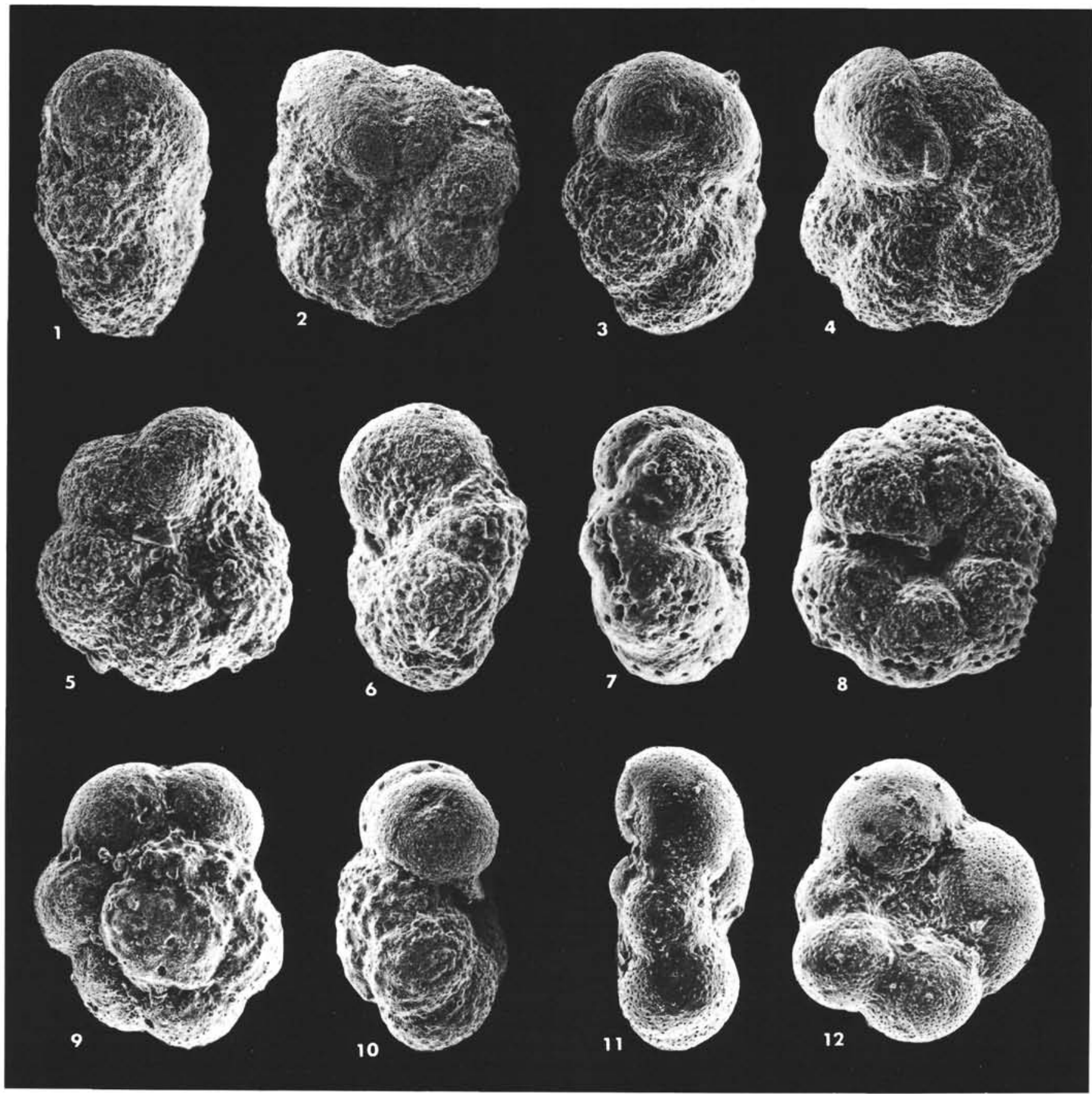

Plate 3. Late Aptian. 1-4. Hedbergella trocoidea, (1-2) 545-51,CC (max. diam. 0.37 mm), (3-4) 545-53,CC (max. diam. 0.37 mm). 5-10. Hedbergella aff. trocoidea, (5-6) 545-54,CC (max. diam. 0.21 mm), (7-8) 545-54-6, 55-58 cm (max. diam. 0.12 mm), (9-10) 545-54-2, 52-56 cm (max. diam. $0.20 \mathrm{~mm}$ ). 11-12. Loeblichella sp., 547A-73,CC (max. diam. $0.27 \mathrm{~mm}$ ). 


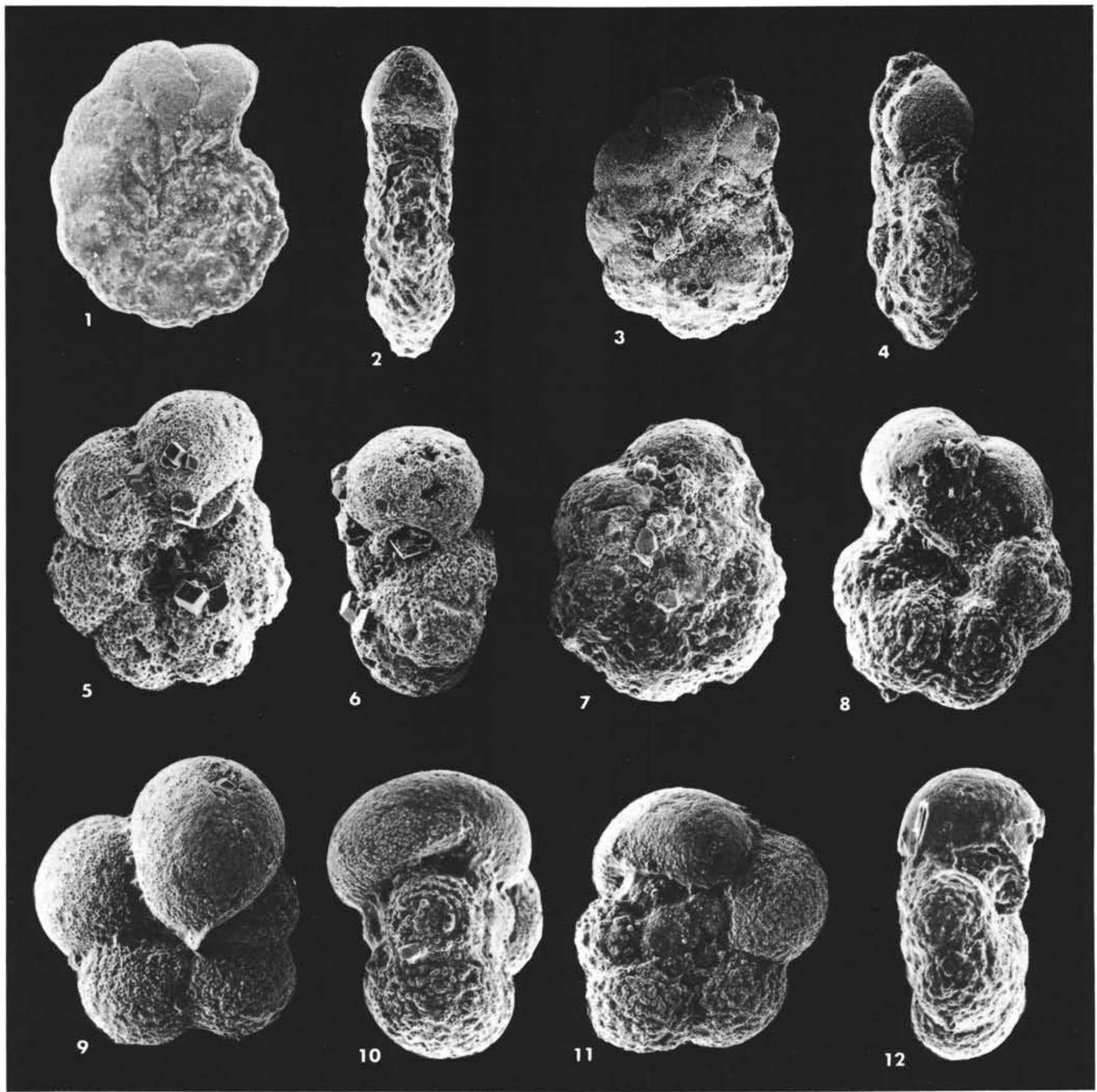

Plate 4. Late Aptian. 1-4. Planomalina cheniourensis, (1-2) 545-49,CC (max. diam. 0.48 mm), (3-4) 545-50-1, 33-34 cm (max. diam. $0.40 \mathrm{~mm}$ ). 5-8, 12. Hedbergella sp. $1,(5-6) 545-56-5,62-64 \mathrm{~cm}(\max$. diam. $0.20 \mathrm{~mm})$, (7) 545-54,CC (max. diam. 0.29 mm), (8, 12) 545-53-2, 63-65 (max. diam. $0.21 \mathrm{~mm}$ ). 9-11. Hedbergella gorbachikae, 545-49,CC, (9) max. diam. 0.26 mm, (10-11) max. diam. $0.21 \mathrm{~mm}$. 


\section{R. M. LECKIE}
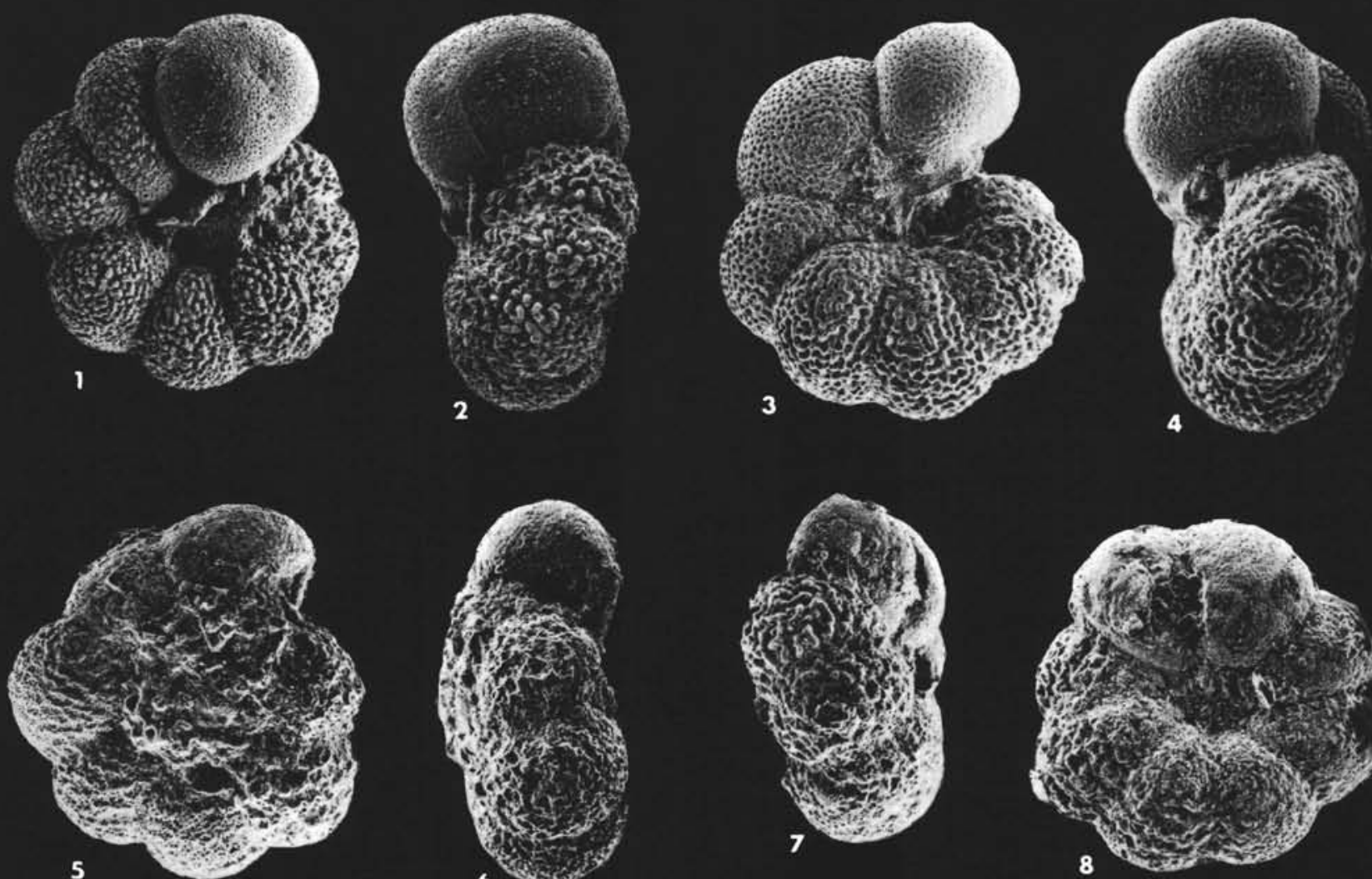

6
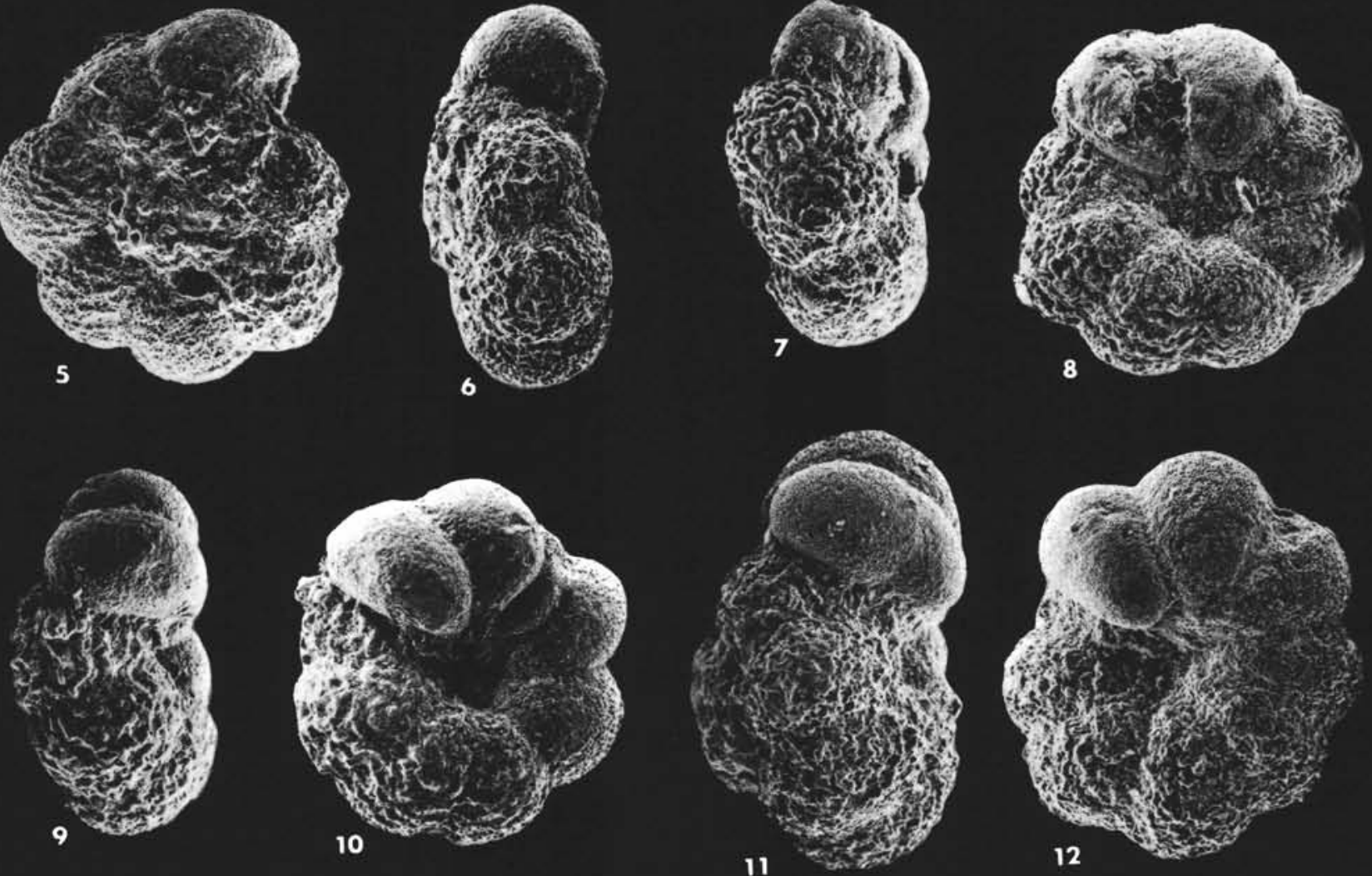

Plate 5. Late Aptian-late Albian. Ticinella roberti s.1. 1-2. 545-38,CC (max. diam. $0.38 \mathrm{~mm})$. 3-4. 547A-62,CC (max. diam. 0.34 mm). 5-6. 545-43-3, 145-150 cm (max. diam. 0.44 mm). 7-8. 545-44,CC (max. diam. 0.37 mm). 9-10. 545-46,CC (max. diam. 0.40 mm). 11-12. $545-49$, CC (max. diam. $0.40 \mathrm{~mm}$ ). 

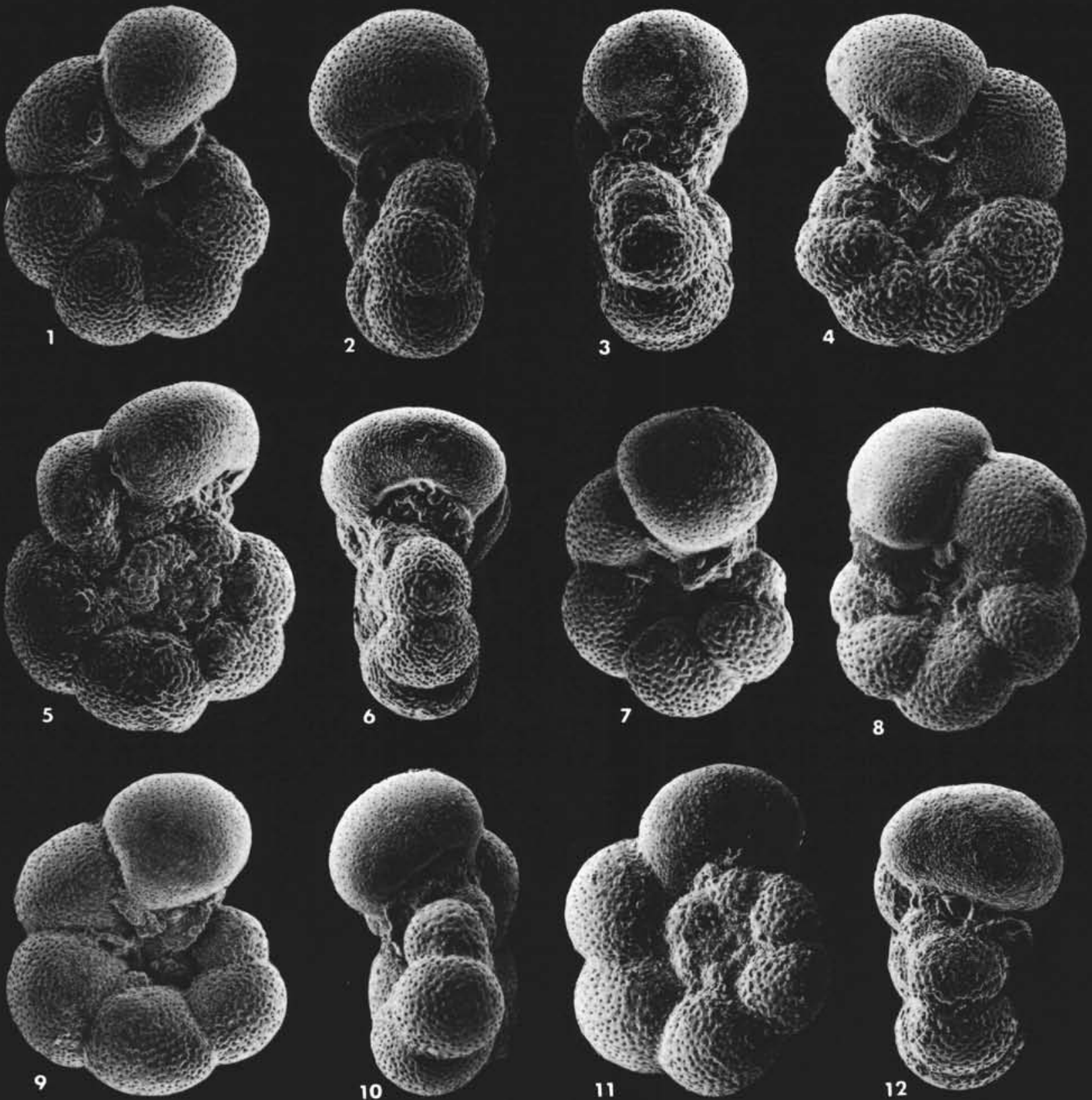

Plate 6. Middle and late Albian. 1-6. Ticinella primula, (1-2) 547A-73, CC (max. diam, 0.42 mm), (3-6) 547A-68,CC (3-4, max. diam. 0.38 mm; 5-6, large specimen with pseudo-planispiral coiling, max. diam. $0.45 \mathrm{~mm}$ ). 7-12. Ticinella madecassiana, (7) 547A-73,CC (max. diam. $0.35 \mathrm{~mm}$ ), (8) 545-39,CC (max. diam. $0.32 \mathrm{~mm}$ ), (9-10) 547B-5,CC (max. diam. $0.35 \mathrm{~mm}),(11-12) 547 \mathrm{~A}-73, \mathrm{CC}$ (max. diam. $0.34 \mathrm{~mm}$ ). 

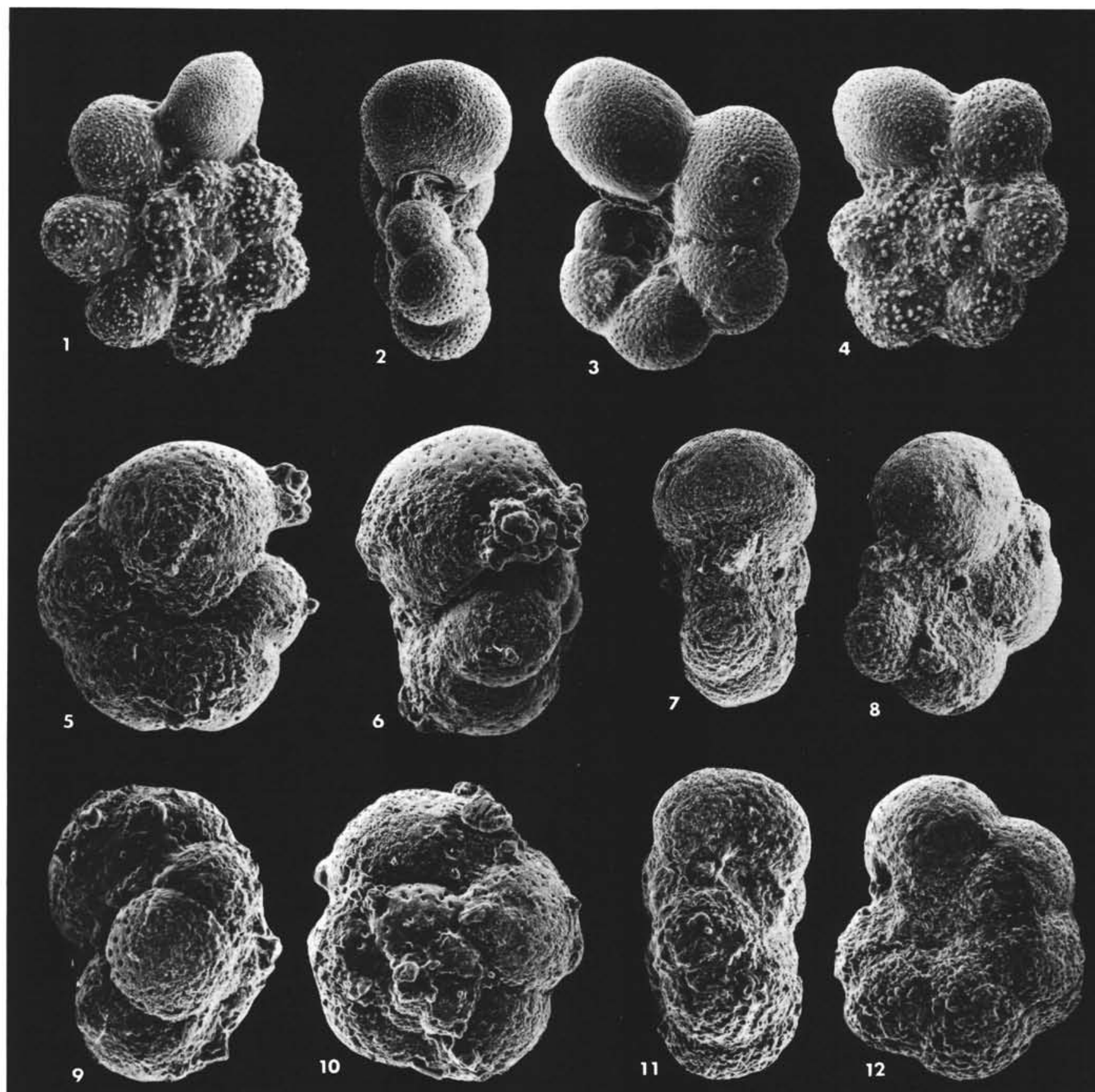

Plate 7. Early to late Albian. 1-4. Ticinella raynaudi s.1., (1) 547A-73,CC (max. diam. $0.38 \mathrm{~mm}$ ), (2-3) 547B-5,CC (max. diam. 0.35 mm). (4) 547B-2,CC (max. diam. $0.31 \mathrm{~mm}$ ). 5-6. Gen. indet., sp. indet., 545-40-6, bottom (max. diam. $0.16 \mathrm{~mm}$ ) 7-8. Globigerinelloides gyroidinaeformis, 545-47-1, 93-95 cm (max. diam. 0.32 mm). 9-10. Gen. indet., sp. indet., 545-40-6, bottom (max. diam. 0.20 mm). 11-12. Hedbergella $\mathrm{cf}$. rischi, 545-46-3, 4-6 cm (max. diam. $0.24 \mathrm{~mm}$ ). 


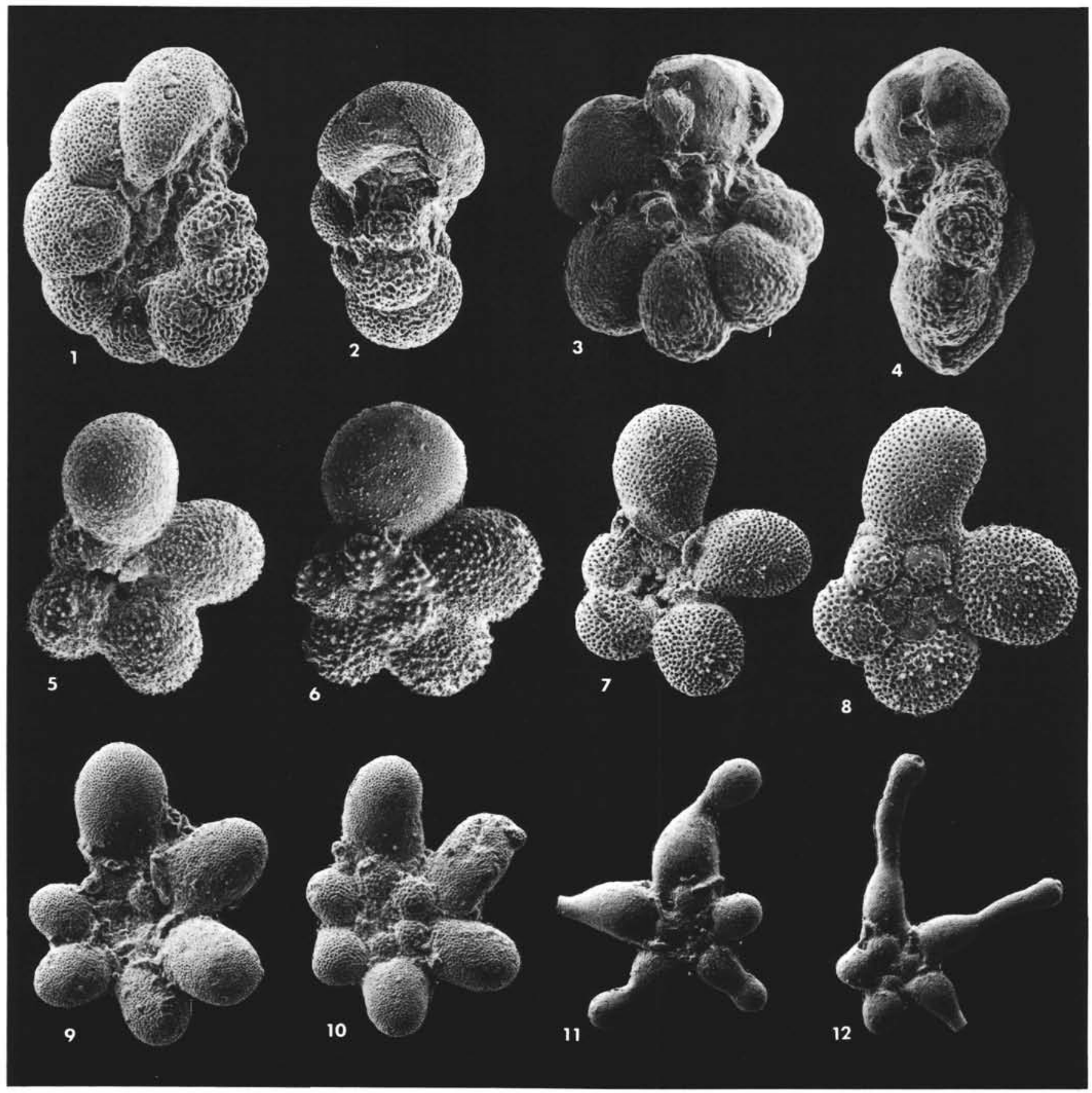

Plate 8. Late Albian, Cenomanian. 1-2. Biticinella breggiensis, 547B-5,CC (max. diam. 0.58 mm). 3-4. Ticinella cf. raynaudi s.l.; note imperforate band in edge view. 547A-66,CC (max. diam. $0.38 \mathrm{~mm})$. 5-6. Hedbergella simplicissima, (5) 547A-42,CC (max. diam. $0.32 \mathrm{~mm})$, (6) 547A-52,CC (max. diam. $0.42 \mathrm{~mm}$ ). 7-8. Clavihedbergella simplex, 547A-40, CC, (7) max. diam. $0.26 \mathrm{~mm},(8) \mathrm{max}$. diam. 0.22 mm. 9-10. Clavihedbergella subcretacea, 547B-5,CC, (9) max. diam. $0.30 \mathrm{~mm},(10) \max$. diam. $0.28 \mathrm{~mm}$. 11-12. Clavihedbergella moremani, 547A-73,CC, (11) max. diam. $0.37 \mathrm{~mm},(12) \mathrm{max}$. diam. $0.43 \mathrm{~mm}$. 


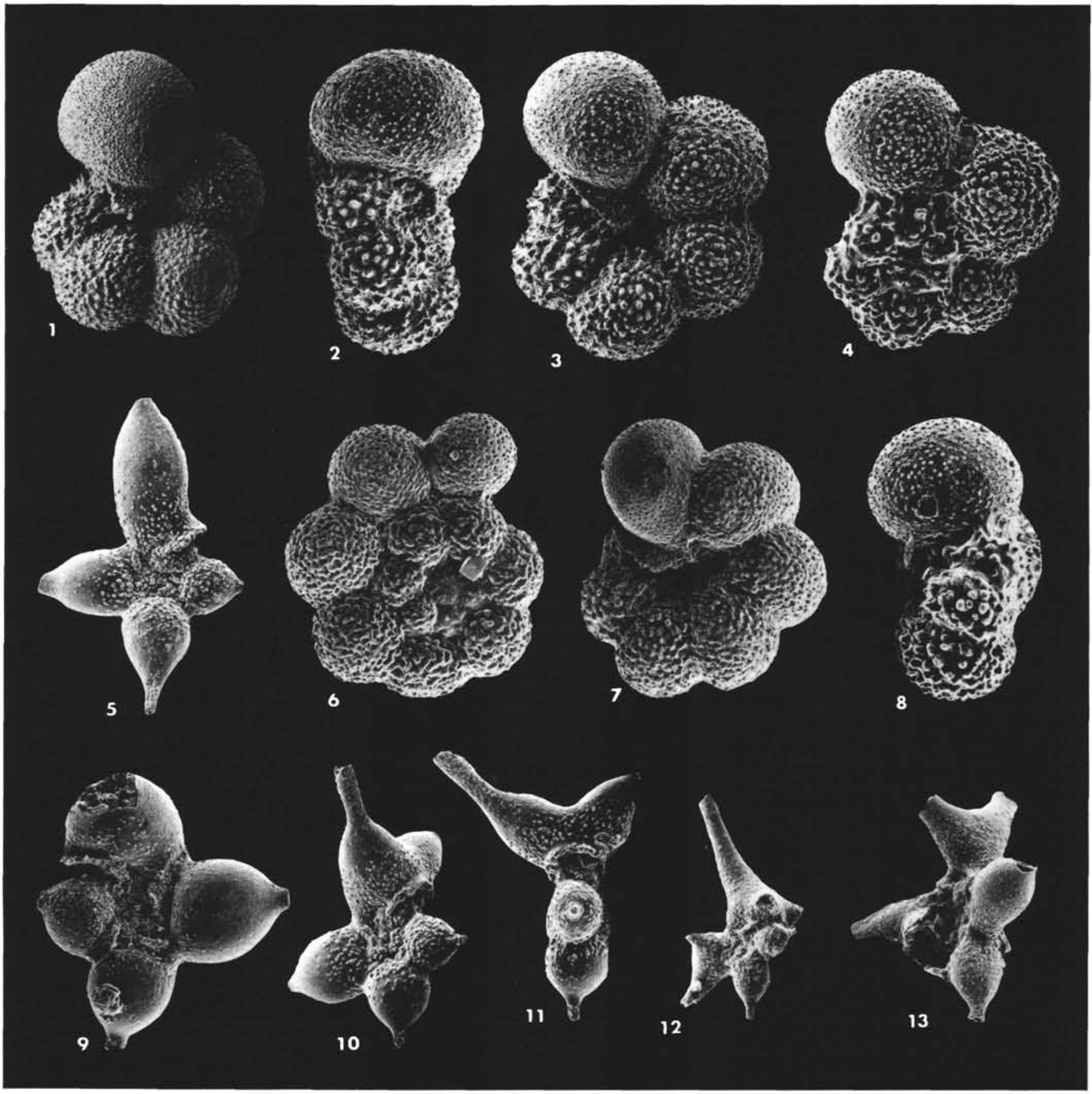

Plate 9. Albian, Cenomanian. 1-4, 8. Hedbergella delrioensis, (1-3) 547A-42,CC (1, max. diam. 0.44 mm; 2-3 max. diam. 0.35 mm), (4, 8) 547A-54,CC (max. diam. $0.35 \mathrm{~mm}$ ). 5. Schackoina cenomana, 547A-41,CC (max. diam. $0.32 \mathrm{~mm}$ ). 6-7. Hedbergella planispira, (6) 547A-73,CC ( $\max$. diam. $0.24 \mathrm{~mm}$ ), (7) 547A-42,CC (max. diam. $0.30 \mathrm{~mm}$ ). 9. Schackoina cenomana, 547A-53,CC ( $\max$. diam. 0.25 mm). 10-11. Schackoina bicornis, 547A-41,CC (max. diam. $0.32 \mathrm{~mm})$. 12. Schackoina multispinata, 547A-42,CC (max. diam. $0.40 \mathrm{~mm}) .13$. Schackoina moliniensis, 547A-53,CC (max. diam. $0.28 \mathrm{~mm}$ ). 

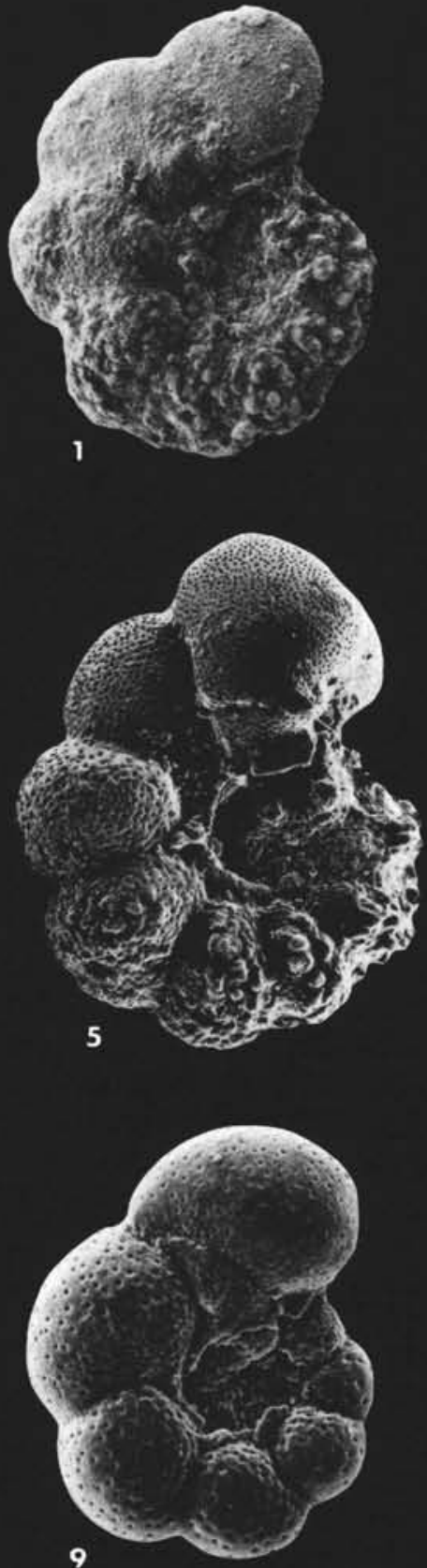
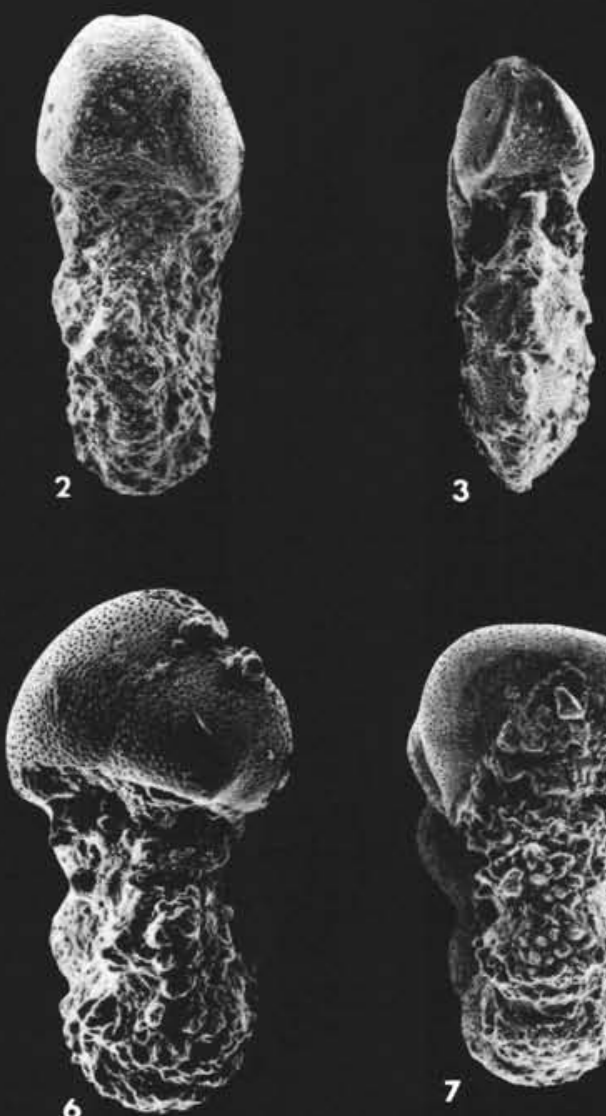

$\boldsymbol{6}$

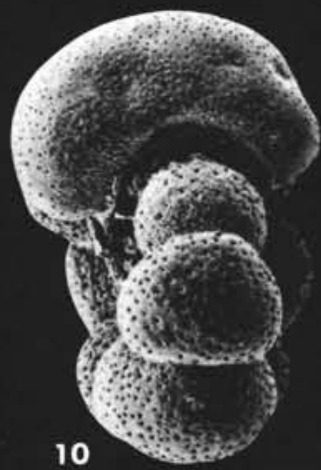

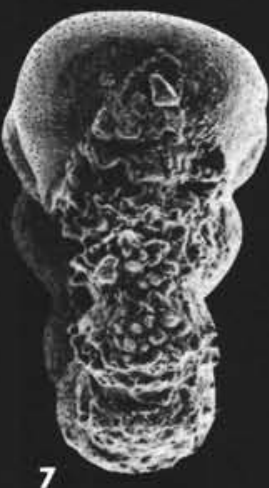

7

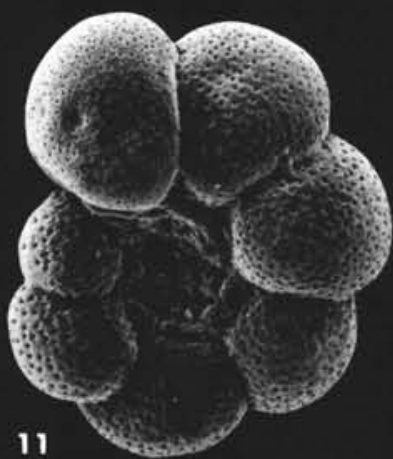

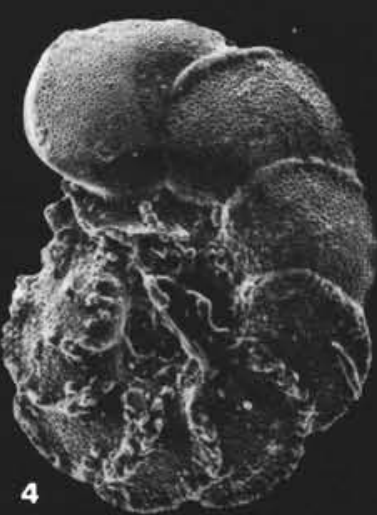

4

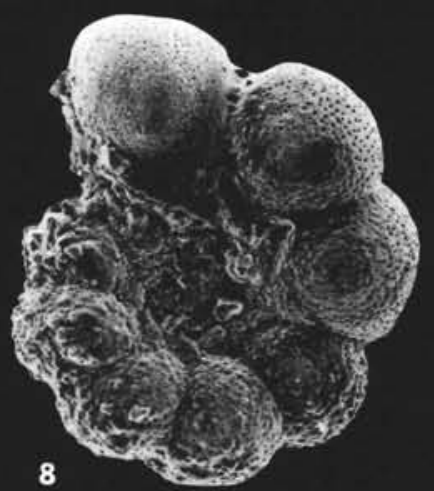

8

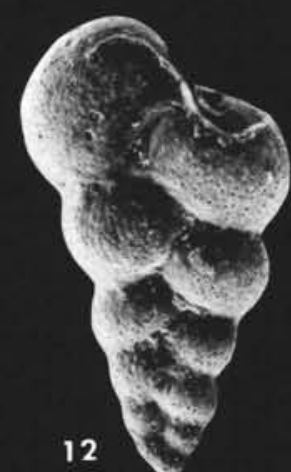

Plate 10. Late Albian, Cenomanian. 1-2.Planomalina praebuxtorfi, 547A-67,CC (max. diam. 0.42 mm). 3-4. Planomalina buxtorfi, 547A63,CC (max. diam. $0.54 \mathrm{~mm}$ ). 5-6. Globigerinelloides cf. bentonensis, transitional specimen between $G$. bentonensis and $P$. praebuxtorfi; 547A-68,CC (max. diam. $0.44 \mathrm{~mm}$ ). 7-11. Globigerinelloides bentonensis, (7-8) 547A-73,CC (max. diam. 0.38 mm), (9) 547A-60,CC (max. diam. $0.27 \mathrm{~mm}$ ). (10-11) 547A-51,CC (max. diam. $0.32 \mathrm{~mm}$ ). 12. Heterohelix moremani, 547A-42,CC (max. diam. $0.26 \mathrm{~mm}$ ). 

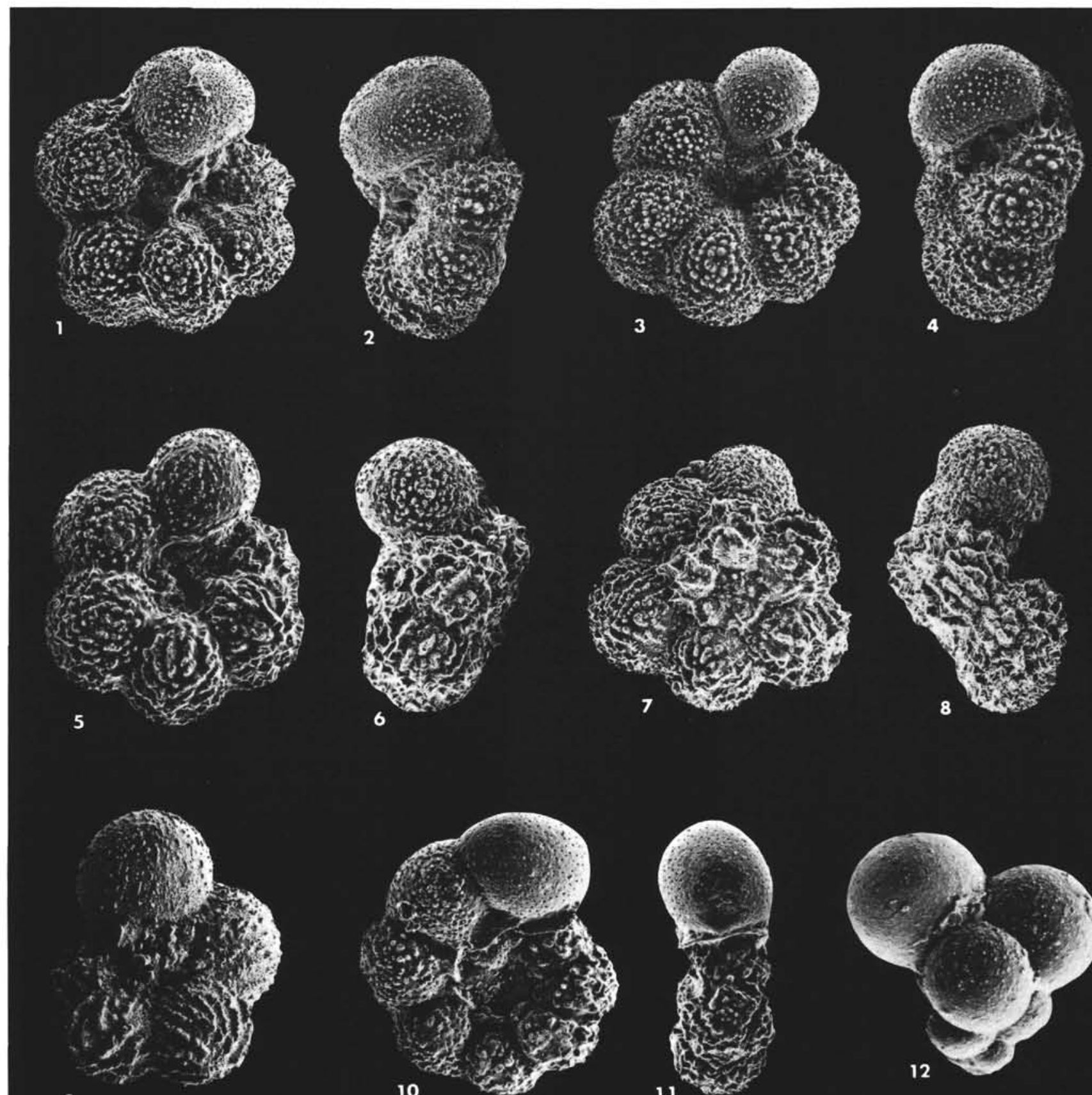

9
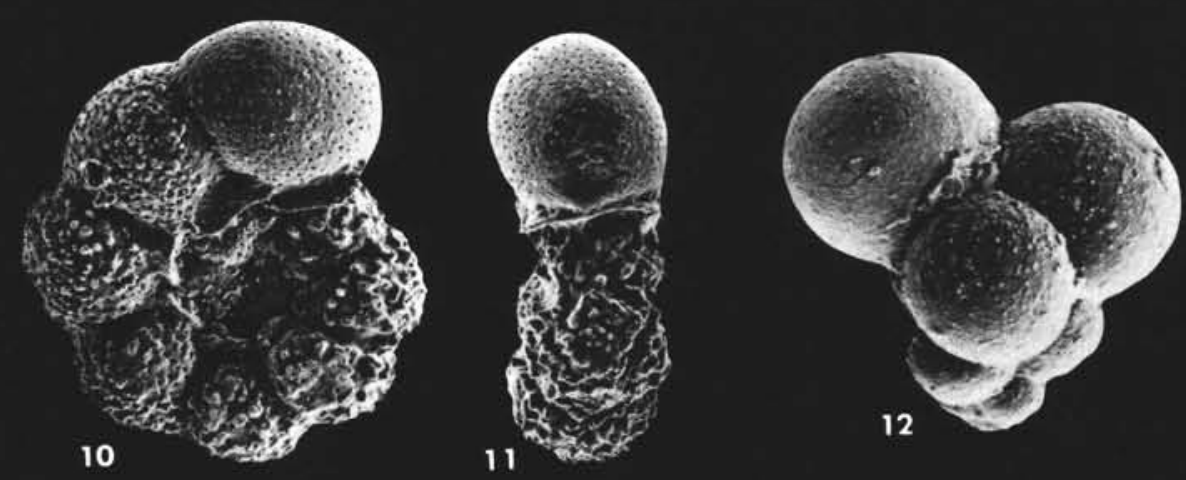

Plate 11. Late Albian, Cenomanian. 1-4. Hedbergella paradubia, $(1,2) 547 \mathrm{~A}-53, \mathrm{CC}$ (max. diam. $0.39 \mathrm{~mm}),(3-4) 547 \mathrm{~A}-40, \mathrm{CC}$ (max. diam. $0.39 \mathrm{~mm}$ ). 5-9. Hedbergella libyca, (5-8) 547A-62,CC (5-6, max. diam. $0.50 \mathrm{~mm}$; 7-8, max. diam. $0.57 \mathrm{~mm}),(9) 545-40-1,8-10 \mathrm{~cm}$ (max. diam. $0.44 \mathrm{~mm}$ ). 10-11. Globigerinelloides ultramicrus, 547A-42,CC (max. diam. $0.26 \mathrm{~mm})$. 12. Guembelitria cenomana, 547A-52,CC (max. diam. $0.15 \mathrm{~mm})$. 


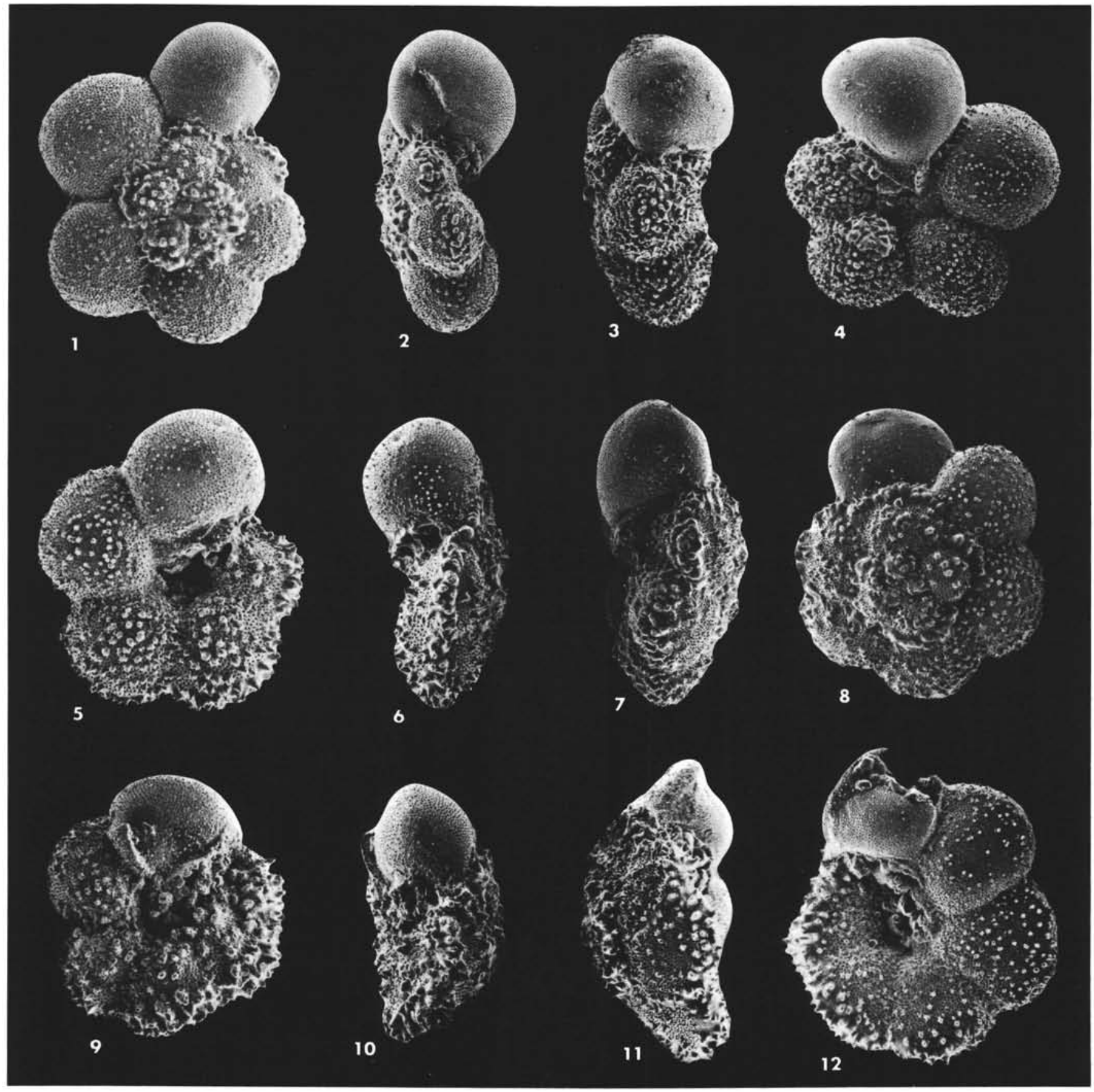

Plate 12. Late Albian-Cenomanian. 1-8. Praeglobotruncana delrioensis, (1-4) 547A-51,CC (1-2, max. diam. 0.51 mm; 3-4, max. diam. $0.47 \mathrm{~mm}$ ), (5-8) 547A-56,CC (5-6, max. diam. 0.39 mm; 7-8, max. diam. 0.56 mm). 9-12. Praeglobotruncana stephani, (9-10) 545-40-1, 8-10 $\mathrm{cm}$ (max. diam. $0.42 \mathrm{~mm}$ ), (11-12) 547A-51,CC (max. diam. $0.54 \mathrm{~mm}$ ). 

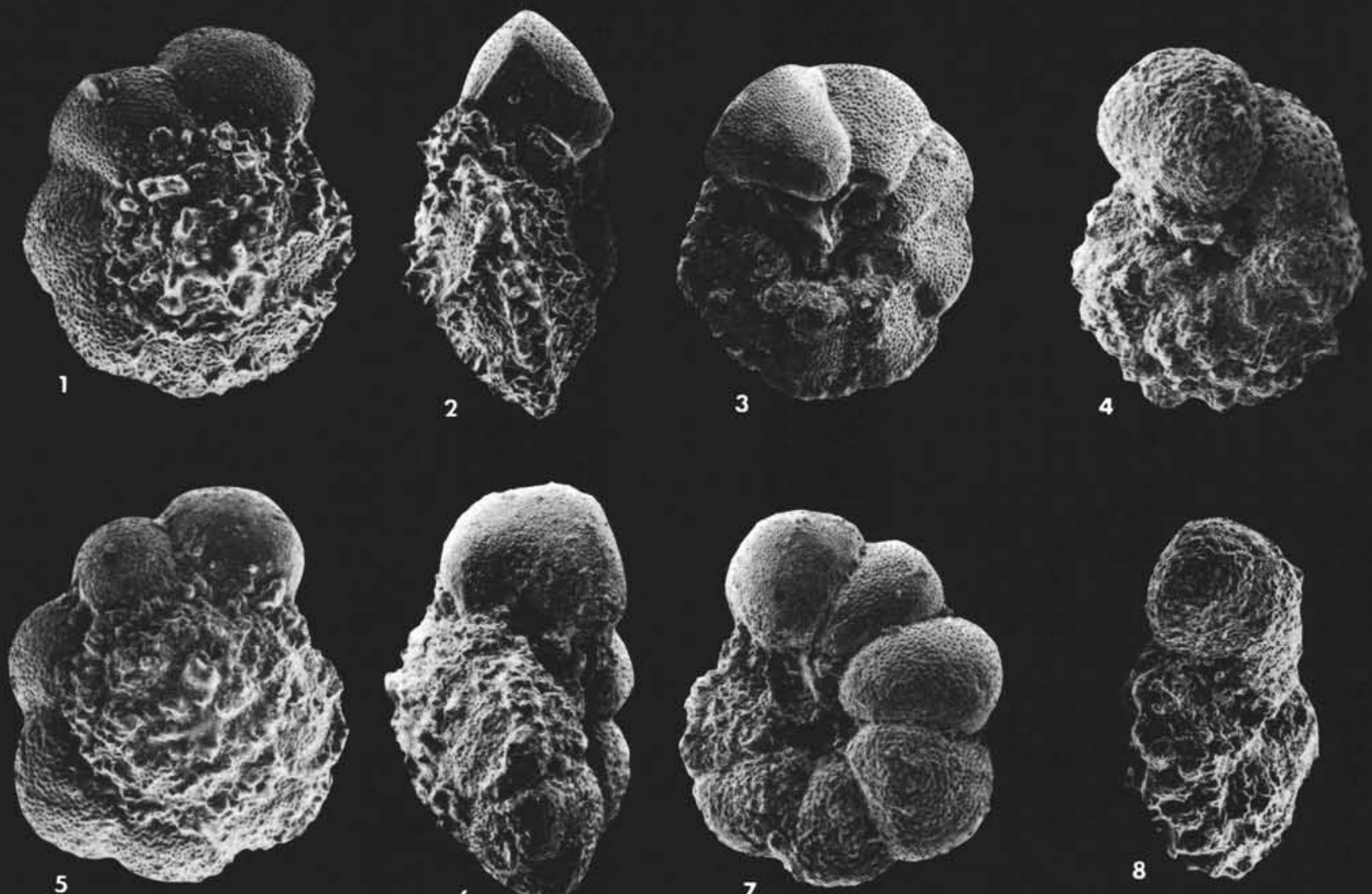

6
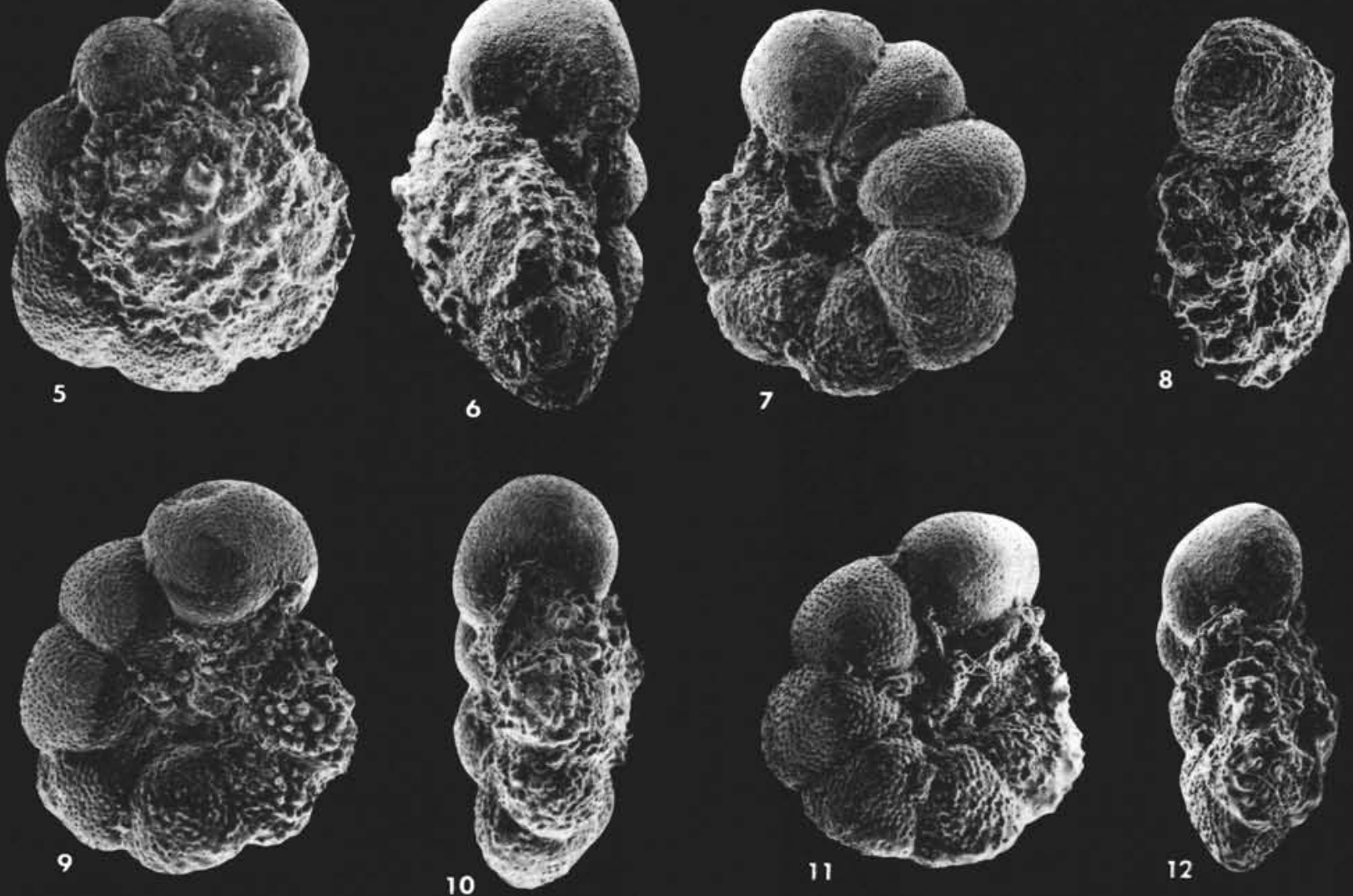

Plate 13. Middle and late Albian. 1-3. Rotalipora ticinensis, 547A-69, CC (max. diam. $0.45 \mathrm{~mm}$ ). 4, 8, 11-12. Rotalipora praebalernaensis, $(4,8) 545-40-3,8-10 \mathrm{~cm}$ (max. diam. 0.24 mm), (11-12) 545-39-3, 96-98 cm (max. diam. 0.36 mm). 5-7. Rotalipora subticinensis, 547B-4,CC (max. diam. $0.53 \mathrm{~mm})$. 9-10. Ticinella praeticinensis, 547B-5,CC (max. diam. $0.43 \mathrm{~mm})$. 


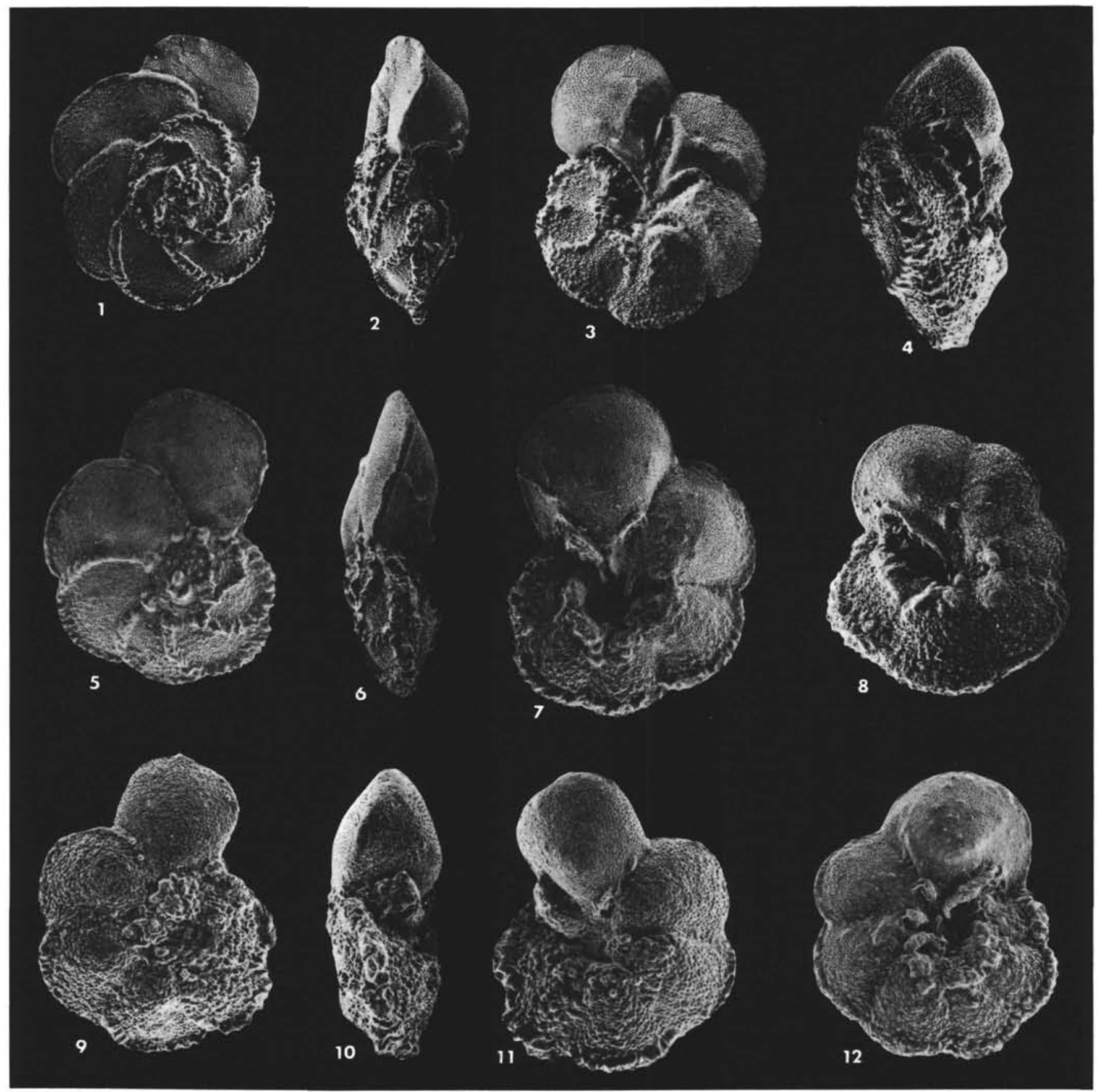

Plate 14. Latest Albian-middle Cenomanian. Rotalipora appenninica. 1-3. Later form, specimen becoming transitional with $R$. aff. cushmani; 547A-40,CC (max. diam. $0.67 \mathrm{~mm})$. 4, 8. 545-35,CC (max. diam. $0.40 \mathrm{~mm})$. 5-7, 12. 547A-62,CC (max. diam. 0.55 mm). 9-11. Early form, 547A-69,CC (max. diam. $0.43 \mathrm{~mm}$ ). 


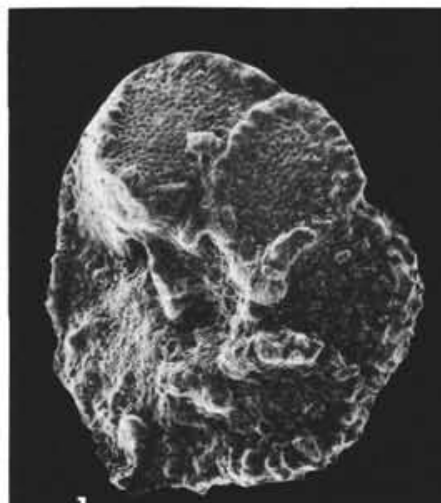

1

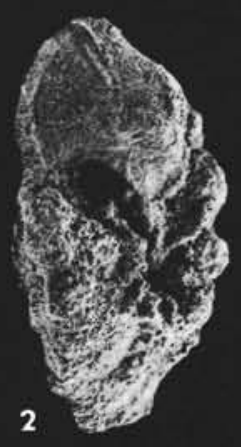

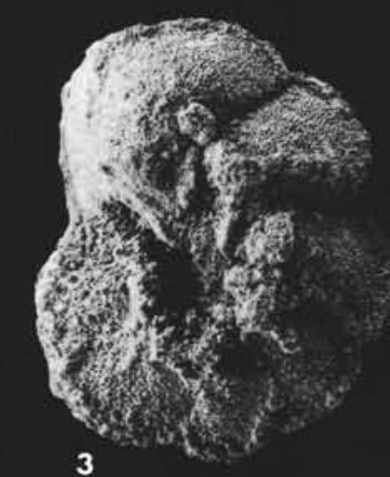

3

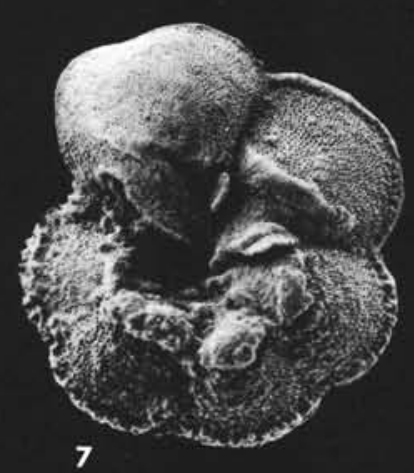

6
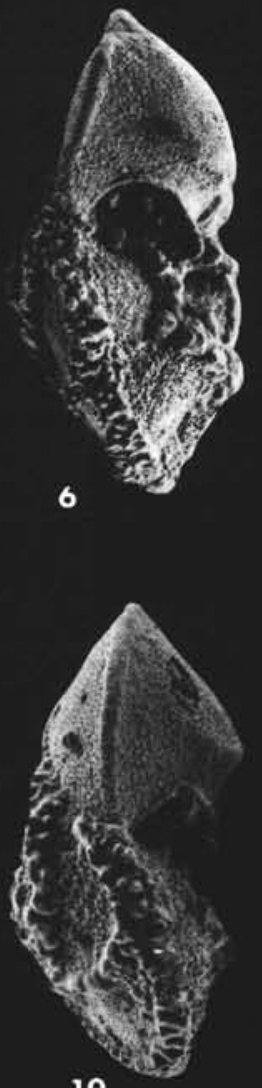

10

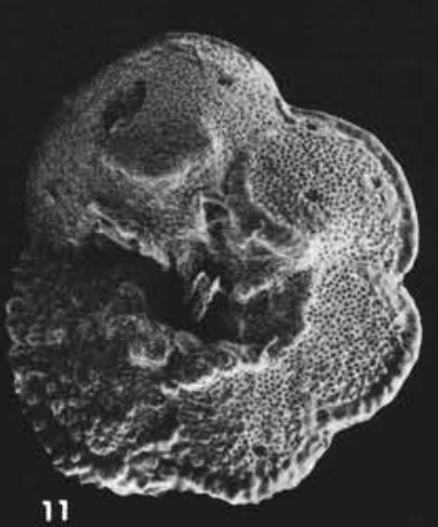

11

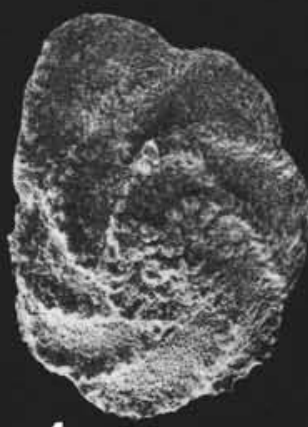

4

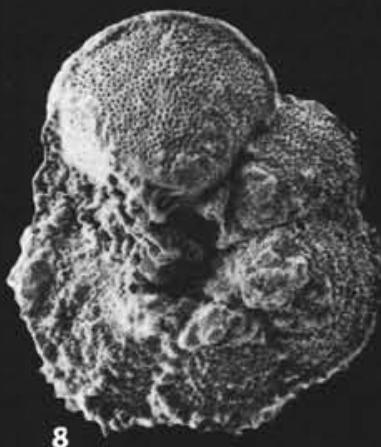

8

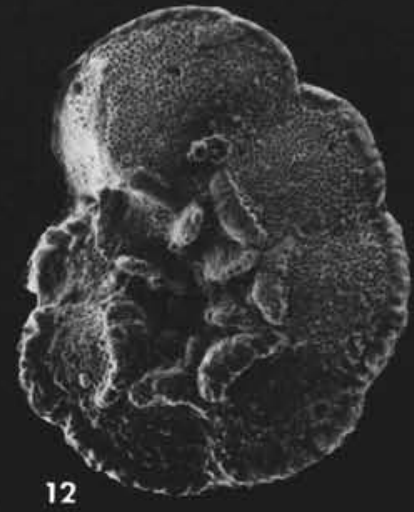

Plate 15. Early and middle Cenomanian. 1-4. Rotalipora greenhornensis, (1) 547A-42,CC (max. diam. 0.37 mm), (2-3) 545-31-1, 25-27 cm (max. diam. $0.64 \mathrm{~mm}$ ), (4) 545-29,CC (max. diam. $0.42 \mathrm{~mm}$ ), 5-12. Rotalipora gandolfii, (5) 547A-44,CC (max. diam. 0.78 mm). (6-7) 545-34,CC (max. diam. 0.58 mm), (8) 545-38-1, 90-92 cm (max. diam. 0.47 mm), (9-12) 547A-53,CC (9-11, max. diam. 0.44 mm; 12, max. diam. $0.46 \mathrm{~mm})$. 


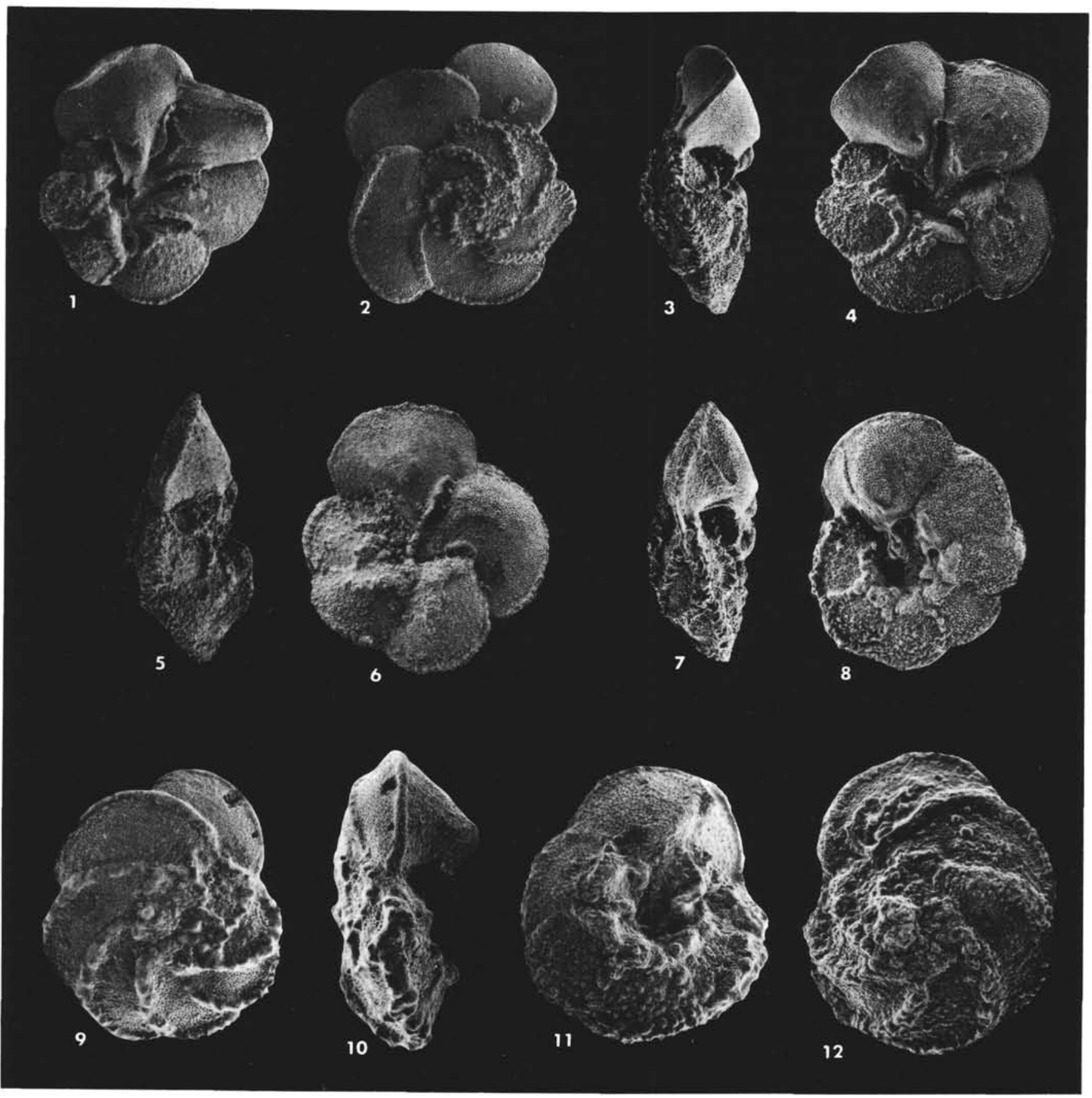

Plate 16. Early and middle Cenomanian. 1-6. Rotalipora aff. cushmani, (1-4) 547A-40,CC (1-2, max. diam. 0.77 mm; 2-4, max. diam. $0.70 \mathrm{~mm}$ ), (5-6) 545-31-1, 25-27 cm (max. diam. 0.62 mm). 7-12. Rotalipora greenhornensis, (7-8) 545-32,CC (max. diam. 0.57 mm), (9-10) 547A-42,CC (max. diam. $0.40 \mathrm{~mm}),(11-12) 545-33, C C(\max$. diam. $0.42 \mathrm{~mm})$. 


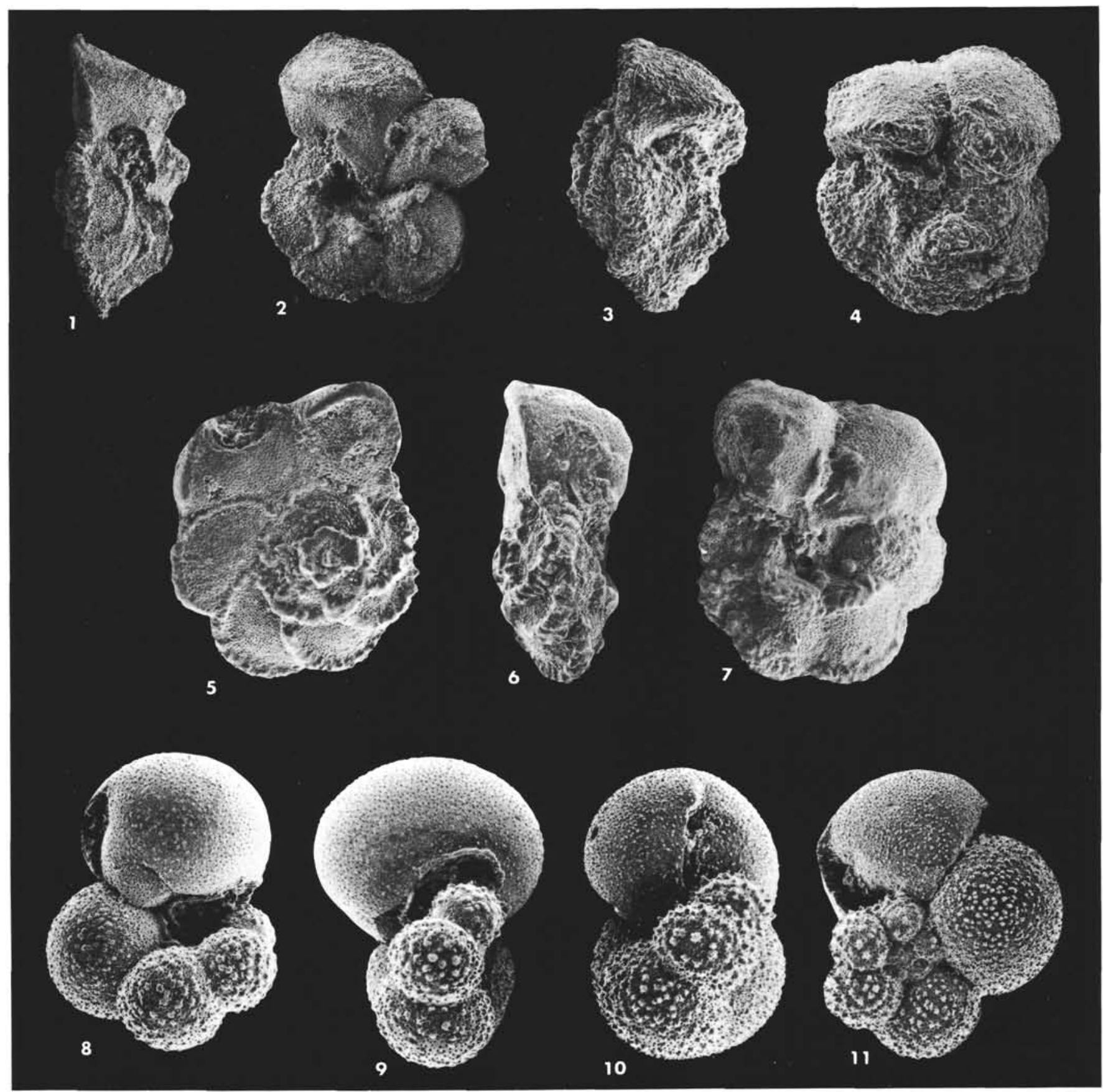

Plate 17. Early and middle Cenomanian. 1-2. Rotalipora reicheli, 545-28-1, 47-49 cm (max. diam. 0.70 mm). 3-7. Rotalipora micheli, (3-4) 545-31,CC (max. diam. $0.48 \mathrm{~mm}$ ), (5-7) 547A-59,CC (max. diam. 0.49 mm). 8-11. Hedbergella sp. 2, 547A-41,CC, (8-9) max. diam. 0.39 mm, (10-11) max. diam. $0.40 \mathrm{~mm}$. 